\title{
An Overview of the Classification, Production and Utilization of Biofuels for Internal Combustion Engine Applications
}

\author{
Omojola Awogbemi ${ }^{1, *(D)}$, Daramy Vandi Von Kallon ${ }^{1}$ D, Emmanuel Idoko Onuh ${ }^{2}$ (D) \\ and Victor Sunday Aigbodion 1,3 \\ 1 Department of Mechanical and Industrial Engineering Technology, University of Johannesburg, \\ Auckland Park Kingsway, Johannesburg 2008, South Africa; dkallon@uj.ac.za (D.V.V.K.); \\ victor.aigbodion@unn.edu.ng (V.S.A.) \\ 2 Department of Mechanical Engineering, Federal Polytechnic, Bauchi 740231, Nigeria; eionuh3@gmail.com \\ 3 Africa Centre of Excellence, ACESPED University of Nigeria, Nsukka 410001, Nigeria \\ * Correspondence: jolawogbemi2015@gmail.com
}

check for updates

Citation: Awogbemi, O.; Kallon, D.V.V.; Onuh, E.I.; Aigbodion, V.S An Overview of the Classification, Production and Utilization of Biofuels for Internal Combustion Engine Applications. Energies 2021, 14, 5687. https://doi.org/10.3390/en14185687

Academic Editor: Gianni Bidini

Received: 9 June 2021

Accepted: 9 July 2021

Published: 9 September 2021

Publisher's Note: MDPI stays neutral with regard to jurisdictional claims in published maps and institutional affiliations.

Copyright: (c) 2021 by the authors. Licensee MDPI, Basel, Switzerland. This article is an open access article distributed under the terms and conditions of the Creative Commons Attribution (CC BY) license (https:// creativecommons.org/licenses/by/ $4.0 /)$.

\begin{abstract}
Biofuel, a cost-effective, safe, and environmentally benign fuel produced from renewable sources, has been accepted as a sustainable replacement and a panacea for the damaging effects of the exploration for and consumption of fossil-based fuels. The current work examines the classification, generation, and utilization of biofuels, particularly in internal combustion engine (ICE) applications. Biofuels are classified according to their physical state, technology maturity, the generation of feedstock, and the generation of products. The methods of production and the advantages of the application of biogas, bioalcohol, and hydrogen in spark ignition engines, as well as biodiesel, FischerTropsch fuel, and dimethyl ether in compression ignition engines, in terms of engine performance and emission are highlighted. The generation of biofuels from waste helps in waste minimization, proper waste disposal, and sanitation. The utilization of biofuels in ICEs improves engine performance and mitigates the emission of poisonous gases. There is a need for appropriate policy frameworks to promote commercial production and seamless deployment of these biofuels for transportation applications with a view to guaranteeing energy security.
\end{abstract}

Keywords: biofuel; biodiesel; emission; feedstock; utilization; transesterification; transportation

\section{Introduction}

Accessibility to clean, safe, and affordable energy has a strong correlation with the quality of life of an individual. With increasing population and urbanization in the 21st century, universal energy accessibility has become one of the greatest challenges in meeting sustainable development goals. The improved economic activities in developing and emerging economies have elicited a rapid upsurge in energy demand with an attendant increase in greenhouse gas (GHG) emissions and, consequently, exacerbated global warming [1]. The continued utilization and consumption of fossil-based (FB) fuels have resulted in the depletion of the finite fuel reserve, emission of dangerous gases, terrestrial and aquatic pollution, climate change, and irreparable environmental degradation. According to British Petroleum, both oil and gas could be exhausted within the next 50 years while coal reserves can only last for the next 115 years based on the current rate of exploitation [2,3]. With these scenarios, research on the development of affordable and sustainable renewable fuels has been escalated to meet the present global energy needs without compromising future sustainability.

Owing to their numerous advantages, including their renewability, environmental friendliness, feedstock availability, the flexibility of the production techniques, and their availability in solid, liquid, and gaseous states, biofuels have gained sustained popularity as an alternative to FB fuels. Other renewable energy systems like solar and wind do not pollute the environment, but they are incapable of sequestrating $\mathrm{CO}_{2}$ emissions and 
generating $\mathrm{O}_{2}$. Thus, bioenergy and biofuels possess the unique ability to sustain the environment and the earth's ecosystem whereas the solar and wind systems have no effects on the natural balance of the earth. For these reasons, among others, the deployment of biofuels, especially as a transportation fuel, has continued to increase every year.

Apart from the dwindling reserves, the exploitation, exploration, and consumption of FB fuels have had severe effects on the environment, leading to an average increase in temperature, urban smog, and acid rain and weakening of the ozone layer. These have resulted in environmentalists and businesses mounting pressure on governments and international communities to implement strategies targeted at mitigating carbon emissions and to advance towards sustainable, less destructive, environmentally benign renewable fuels. Global fossil fuel consumption has increased from 47,566 terawatt hours (TWh) in 2008 to about 58,181 TWh in 2018. The main products of refined crude oil, gasoline and diesel, are used in internal combustion engines (ICEs). Road transportation alone consumes about $49 \%$ of the total global oil and leads to GHG emissions [4,5]. Available data indicate that global biofuel production grew from a mere 9.2 million metric tons of oil equivalent (Mtoe) in 2000 to 63.15 Mtoe, 80.33 Mtoe, and 95.38 Mtoe in 2010, 2015, and 2018, respectively [6]. The United States of America (USA), Brazil, and Indonesia were the most prominent biofuel producers, while China and the USA topped the fossil fuel consumption chart in 2018 (Figure 1). In terms of market size, global biofuel value is projected to reach USD 132.7 billion by 2023 [6]. This remarkable growth, which is expected to persist for the foreseeable future, is propelled by the use of waste materials as feedstock, sustainability criteria, energy security, and import tariffs.

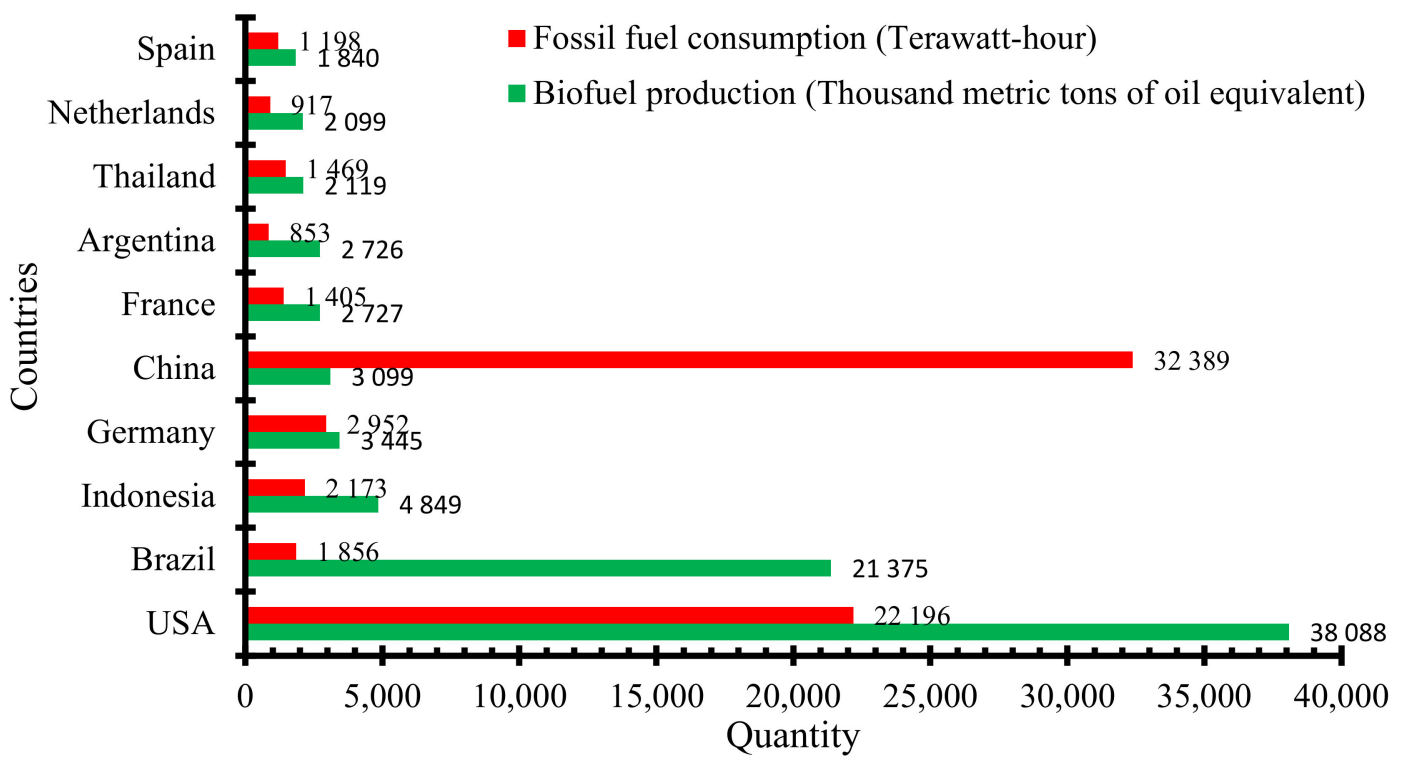

Figure 1. Leading biofuel producers and their fossil fuel consumption in 2018. Adapted from [5,7]. Developed by the authors.

Research has been conducted on the exploitation and utilization of renewable fuel, especially biofuel. Lee et al. [8] identified thermochemical and biochemical technologies as the leading pathways for converting waste to bioenergy. They stated that the transesterification process is the easiest and most cost-effective route to large-scale synthesis of biodiesel from waste. Investigations into further developing household and commercial production of biodiesel are still ongoing. Researchers have also reviewed perspectives on biofuels along with their history, status, and classifications for various applications [9-11]. There is a consensus of opinion on the need for more investigations to fill the identified research gaps on the production technologies and classification of biofuels and their utilization as alternative fuels in ICEs, bioelectricity, bioenergy, and other applications. This forms the motivation for this present effort. This study aims to provide an overview of biofuel as 
a form of renewable fuel in terms of the classifications of biofuels, as based on various defined parameters, their production, and the utilization of biodiesel and other renewable fuels for internal combustion application. Sequentially, after classifying biofuels, the generation and applications of biodiesel, biogas, bioalcohol, hydrogen, Fischer-Tropsch (F-T) fuel, and dimethyl ether (DME) as transportation fuels are presented. While focusing on biodiesel as an alternative renewable fuel, the effects of the use of some biofuels on the performance and emission characteristics of ICEs are also discussed. The current study is limited to describing the classification of biofuels, the transesterification process for biodiesel synthesis, and the application of bioalcohol (methanol, ethanol, and butanol), biogas, and hydrogen in spark ignition engines, as well as the use of biodiesel, F-T fuel, and DME in compression ignition (CI) engines. The required information for this review was sourced from recently published articles.

\section{Biofuel as a Renewable Fuel}

Since the early 1970s, when the word "biofuel" was first used, authors have defined the term as: (a) a fuel manufactured either from or by fresh, living micro- or macroorganisms [12]; (b) a fuel made directly or indirectly from biomass [13]; (c) a liquid fuel obtained from biomass, e.g., biodiesel produced from fats and oils, biogas generated from animal waste, etc. [14]; (d) a bio-based fuel naturally obtained from wood and wood chips or agricultural residues or chemically converted from biomass to charcoal, biodiesel, bioethanol, and biomethane [15]. Using these definitions, we can summarize that biofuel is generated from plants, animal waste, manure, sludge, etc., in either a solid, liquid, or gaseous form, and is capable of being converted to another variety of biofuel [16]. Major benefits and paybacks derivable from the deployment of biofuels as a form of renewable fuel include:

1. Biofuels are renewable and are carbon- and $\mathrm{CO}_{2} / \mathrm{GHG}$-neutral during the progression of the life cycle [17].

2. Less GHG emissions are generated from the utilization of biofuels compared to FB fuels [18,19].

3. Biofuels are biodegradable, sustainable, and environmentally benign $[20,21]$.

4. Biofuels are largely produced from locally available and accessible resources, applying safe production methods [22,23].

5. Production and utilization of biofuels enhance home-grown agricultural development and investment [24,25].

6. Biofuels provide improvements in the health and living conditions of people $[24,25]$.

7. Biofuels create jobs and improvements in local livelihoods and reduce energy importations [26,27].

8. Economically, biofuel helps to stabilize energy prices, conserve foreign exchange, and generate employment at the macroeconomic level $[28,29]$.

9. Household usage of biofuel does not trigger life-threatening health conditions, as opposed to FB fuels [30,31].

Notwithstanding these advantages, the high initial cost of production and storage of biofuels can be a deterrent for potential producers and users. There are justifiable concerns that the increased demand for biofuel will increase the cost of the relevant agricultural and woody raw materials, as well as other feedstocks [32,33]. Also, continuous demand for wood can lead to rapid deforestation, while huge parcels of land are required to cultivate special trees and other inedible oils for biofuel production. In specific terms, methane, a major component of biogas, is a major contributor to global climate change and continuous usage of biogas can exacerbate ozone layer depletion [34], while biodiesel, a form of biofuel, generates high NOx emission and contributes to higher engine wear compared to FB fuel [35]. Despite the obstacles, biofuel is a clean, sustainable, and affordable energy resource choice that can replace FB fuels and rescue humankind from the looming environmental disaster. The adaptation of biofuels as sustainable fuels in various sectors of the economy is one of the strategies for $\mathrm{CO}_{2}$ reduction and carbon mitigation [36,37]. 


\subsection{Classification of Biofuels}

For this work, biofuels are categorized based on four parameters, namely physical state, technology maturity, generation of feedstock, and generation of products.

\subsubsection{Classification Based on the Physical State}

In principle, any renewable and biological substance can be utilized as fuel; thus, various raw materials can be considered as biofuels and can exist in the following three physical states.

\section{Solid Biofuels}

Generally, any solid biomass material can be described as solid biofuel. Solid biomass is principally any solid feedstock that can be converted into biofuel [38]. Examples of such solid biomass include lignocellulosic biomass and various types of solid waste [39]. Table 1 shows various categories of solid biofuel and their examples. Ideally, each of these raw solid biomasses can be used directly as solid biofuels or as feedstock for other forms of biofuel production.

Table 1. Categories and examples of solid biofuel [40-44].

\begin{tabular}{|c|c|c|c|}
\hline \multicolumn{3}{|c|}{ Lignocellulosic Biomass } & \multirow[b]{2}{*}{ Solid Waste } \\
\hline $\begin{array}{l}\text { Agricultural } \\
\text { Residues }\end{array}$ & Forest Residues & Energy Crops & \\
\hline $\begin{array}{l}\text { Rice straw } \\
\text { Rice husk } \\
\text { Wheat straw } \\
\text { Sorghum straw } \\
\text { Corn stover } \\
\text { Sugarcane bagasse } \\
\text { Sugarcane peel } \\
\text { Barley straw } \\
\text { Olive pulp } \\
\text { Grapeseed }\end{array}$ & $\begin{array}{c}\text { Firewoods } \\
\text { Wood chips } \\
\text { Wood branches } \\
\text { Sawdust } \\
\text { Fruit bunch } \\
\text { Willow chips } \\
\text { Black locust } \\
\text { Pine } \\
\text { Spruce } \\
\text { Eucalyptus } \\
\text { Softwood } \\
\text { Hardwood } \\
\text { Hybrid poplar }\end{array}$ & $\begin{array}{c}\text { Switchgrass } \\
\text { Miscanthus } \\
\text { Energy cane grass } \\
\text { Hybrid Pennisetum } \\
\text { Triarrhena } \\
\text { lutarioriparia } \\
\text { Energy cane leaf } \\
\text { Energy cane stem } \\
\text { Grass leaf } \\
\text { Grass stem }\end{array}$ & $\begin{array}{c}\text { Municipal solid waste } \\
\text { Processed paper } \\
\text { Plastics } \\
\text { Wastewater sludge } \\
\text { Food waste } \\
\text { Dried animal manure } \\
\text { Poultry waste }\end{array}$ \\
\hline
\end{tabular}

Compiled by the authors.

\section{Liquid Biofuels}

Liquid biofuels refer to any renewable fuel in liquid form. They are mainly used as transport fuels. In 2019, liquid biofuel production increased to 96 Mtoe from 82.31 Mtoe and 8.57 Mtoe produced in 2016 and 1990, respectively [45,46]. Notable examples of liquid biofuels are biodiesel, biomethanol, bioethanol, biobutanol, biopropanol, bio-oil, jet fuel, etc. [47-49]. Some of the features and benefits that have escalated research and helped popularize the application of liquid biofuels include the following [50]: (i) their high combustibility, (ii) they are safer and easy to store, (iii) they are easy to transport with pipelines, (iv) they are safer to transport compared to petrol, (v) they are relatively inexpensive, (v) they have a high energy to mass ratio, (vi) their storage stability, and (vii) they are reasonably nonexplosive.

\section{Gaseous Biofuels}

Biogas/biomethane, biohydrogen, and biosyngas are the commonest examples of gaseous biofuels. They have a wide variety of applications, including for thermal, transport, and heat uses and electricity/power generation. Over the years, gaseous biofuels have been extensively studied and utilized due to the many benefits derivable from them, which include [51]: (i) higher reactivity, (ii) generation of less waste when applied, (iii) the fewer oxidants required, (iv) the simplicity of the reactors, and (v) ease of control. 


\subsubsection{Classification Based on Technology Maturity}

According to the degree of technology maturity or status of the commercialization technologies, biofuels are often categorized as conventional biofuels and advanced biofuels, as shown in Figure 2.

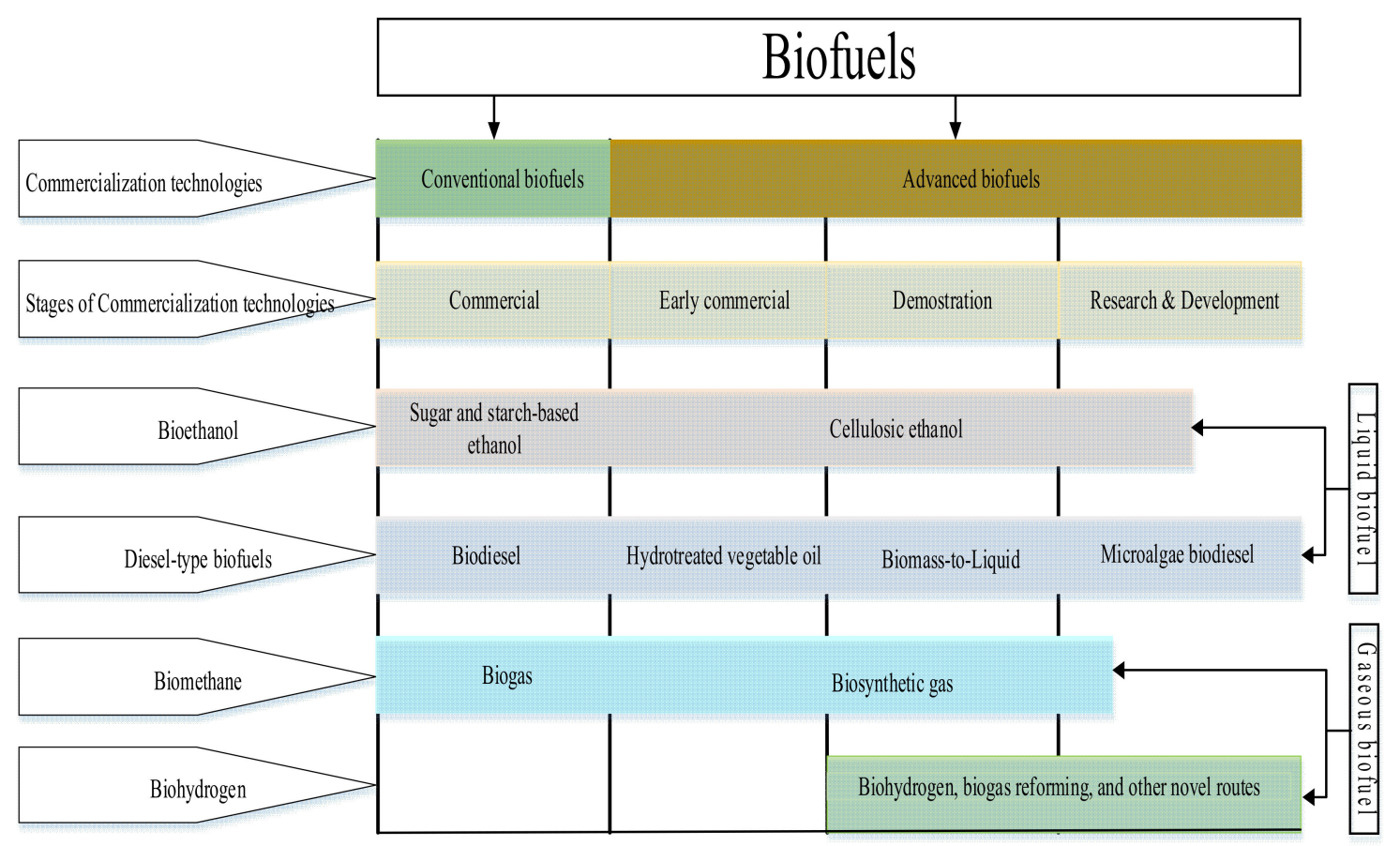

Figure 2. Classification of biofuels based on technology maturity. Adapted from [52]. Developed by the authors.

\section{Conventional Biofuels}

Conventional biofuels are produced through already commercially available technologies. Such technologies continue to be developed for economic viability and profitability. Examples of conventional biofuels include bioethanol, biodiesel, and biogas which are produced through fermentation, transesterification, and anaerobic digestion, respectively. These technologies have been developed, commercialized, and adapted for local or household deployment. Common feedstocks for conventional biofuels include sugarcane and sugar beet, corn, wheat, vegetable oil, animal fat, recovered household fat, waste frying oil, etc. The commercialization of these categories of renewable fuel is hampered by high production costs and unprofitable retail prices [53].

\section{Advanced Biofuels}

The conversion technologies for most advanced biofuels are still generally at the research and development, demonstration, or early commercial stages. Major examples include hydrotreated vegetable oil, lignocellulosic bioethanol, biomass-generated esters, microalgae biodiesel, and biohydrogen. Bearing in mind the challenges of shortages of feedstock, the interference of some feedstocks with the food chain, and the poor cost competitiveness associated with conventional biofuels, investment in and production of advanced biofuels from inedible feedstocks has become an encouraging alternative. However, the adaptation and commercialization of advanced biofuel are hampered by poor fuel economy [54]. Some inedible feedstocks, conversion technologies, and examples of advanced biofuels are shown in Figure 3. 


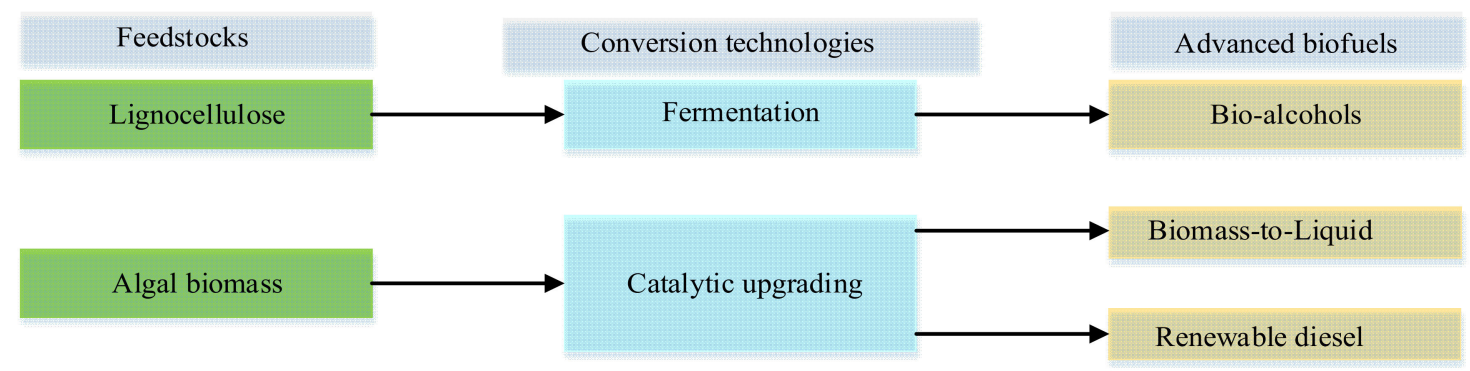

Figure 3. Feedstocks, conversion technologies, and examples of advanced biofuels. Adapted from [54]. Developed by the authors.

\subsubsection{Classification Based on the Generation of Feedstock}

Feedstocks for biofuel production are divided into three categories in terms of their generation: first-generation feedstock, second-generation feedstock, and third-generation feedstock. The choice of feedstock has a huge influence on the development and utilization of biofuel as a substitute for FB fuels. Feedstocks are chosen based on price, hydrocarbon content, and biodegradability. For example, edible feedstocks and those containing pure sugars are relatively expensive. Simple sugars are preferred as feedstocks because they are easy to decompose with microbes while lignocellulosic biomasses are selected based on their relative affordability.

\section{First-Generation Feedstock}

The first sets of raw materials that were converted to biofuels are referred to as firstgeneration feedstock (1GF). Major examples of 1GF include rapeseed oil, soybean oil, palm oil, sunflower oil, corn, sugarcane, wheat, and sugar beet. The extracted oils are converted to biodiesel through the transesterification process while ethanol, a form of bioalcohol, is produced from corn, sugarcane, etc., by direct fermentation [55]. A schematic illustration of ethanol production from corn is shown in Figure 4. Due to the low production cost, good cost/yield ratio, and a large number of carbohydrates in starch or saccharose form in corn and sugarcane, the use of these feedstocks has gained prominence and become an industrial standard [56]. However, the need for large tracts of arable land to cultivate the plants, deforestation, exploitation of natural ecosystems, bush burning, drastic changes to the ecosystem as a result of increased farming activities, the food vs. energy debate, and spikes in the prices of the edible oils used for biodiesel are major drawbacks of the use of this generation of feedstock. Also, the feedstock conversion processes are influenced by the physical attributes of the biomass. The products of 1GF generate a larger carbon footprint compared to other generations of biofuel. These shortcomings prompted researchers to look for microorganisms and other forms of feedstock to respond to the escalated requests for biodiesel and ethanol $[57,58]$.

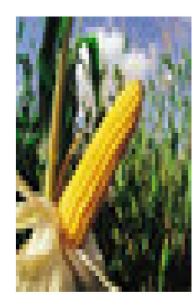

Corn

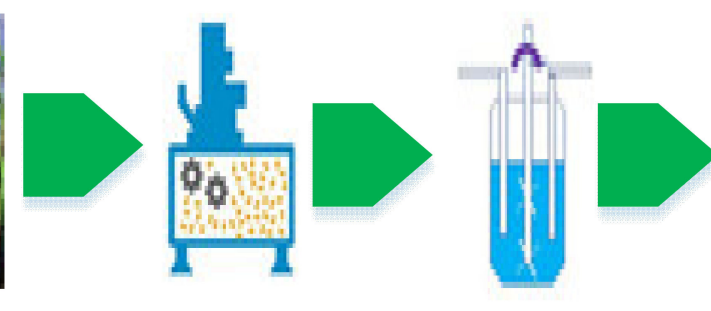

Milling

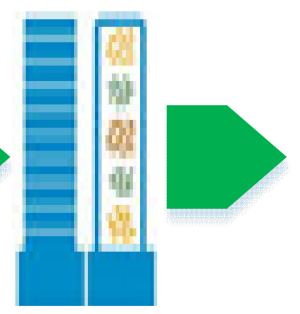

Distillation

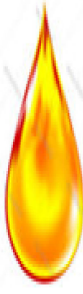

Ethanol

Figure 4. Schematic illustration of ethanol production from first-generation feedstock. Adapted from [58]. Developed by the authors. 


\section{Second-Generation Feedstock}

Lignocellulosic biomasses are generally referred to as second-generation feedstock (2GF) and are converted to bioethanol and biodiesel. The lignocellulosic biomasses are always pre-treated before conversion. For this purpose, four pre-treatment processes, namely, physical, biological, chemical, and combinatorial (physicochemical and biochemical), are commonly adopted. Apart from the pre-treatment processes, other procedures implemented for the transformation of lignocellulosic biomass to bioethanol include hydrolysis, fermentation, and distillation [59]. 2GF biofuels include cellulose, hemicellulose, and lignin. Cellulose and hemicellulose are polysaccharides and are converted to monomeric sugars by fractionalization while monomeric sugars are used for the production of bioethanol through microbial fermentation. Lignin is a complex aromatic polymer of polyphenols and not only forms a bond between hemicellulose and cellulose but also functions as an obstacle to the saccharification of hemicellulose and cellulose. Though lignocellulosic biomass does not affect food chains and is seen as an economically feasible feedstock for producing renewable fuels, its product also has several limitations. The conversion of 2GF to biofuel suffers from many technical challenges and lacks a mature conversion technology, which makes its conversion uneconomical and unsustainable [60].

\section{Third-Generation Feedstock}

Third-generation feedstock (3GF) originates from non-food sources. Algae, which are subdivided into macroalgae and microalgae, are a major example of 3GF. Table 2 shows the features of microalgae and macroalgae. Microalgae are microscopic unicellular photosynthetic microorganisms from which a larger amount of biomass can be generated than from terrestrial plants. They are usually over $400 \mu \mathrm{m}$ in size, between $1 \mu \mathrm{m}$ to $30 \mu \mathrm{m}$ in diameter [61], and can convert algal biomass, waste, and $\mathrm{CO}_{2}$ into diverse bioenergy products by photosynthesis. Microalgae grow rapidly with small quantities of water per $\mathrm{kg}$ of biomass, produce a large number of lipids and starch for biofuel synthesis, and are capable of sequestering $\mathrm{CO}_{2}$ from flue gas [62,63]. Macroalgae are multicellular marine organisms with low concentrations of cellulose and lipid and high levels of structural polysaccharides but no lignin content [64]. Macroalgae, also called seaweed, are capable of growing to up to $60 \mathrm{~m}$ in length [65]. Microalgae are categorized according to their availability while macroalgae are grouped in terms of their photosynthetic pigmentations, as shown in Figure 5.

Algal biomass derives $\mathrm{CO}_{2}$ from power plant emissions and uses $\mathrm{CO}_{2}$ for its growth. The biomass is converted to $\mathrm{CO}_{2}$ by photosynthesis, which emits oxygen into the atmosphere. The cultivation and utilization of algae as a feedstock for biofuel production is one of the strategies for achieving $\mathrm{CO}_{2}$ mitigation. Algae are organisms that grow quickly in salty water, municipal wastewater, and coastline water and on land that is not useful for farming [66,67]. Algal biomass can be grown naturally or artificially. The strategies for artificial microalgae and macroalgae biomass production include open pond cultivation, photobioreactors (phototrophic reactors), and heterotrophic aerobic fermenters [68]. Algae has been widely used as a sustainable biofuel feedstock due to its fast rate of acclimatization to potentially challenging environments, the increased popularity of algae-based biofuels, and the derivation of other associated bio-products, including natural cosmetics, aquaculture, oils, pigments, pharmaceuticals, and nutritional supplements [69].

Table 2. Features of microalgae and macroalgae $[70,71]$.

\begin{tabular}{ccc}
\hline Basis & Macroalgae & Microalgae \\
\hline Cell & Multicellular plant & Unicellular plant \\
Growth habitat & Saline and freshwater & Saline and freshwater \\
Growth rate & Low & Fast \\
Size & $60 \mathrm{~m}$ in length & Small size $(1 \mu \mathrm{\mu m})$ \\
Nutrient storage capacity & High & More \\
Uses & For food and extraction of hydrocolloids & For food, fuel, and medical supplements \\
\hline
\end{tabular}




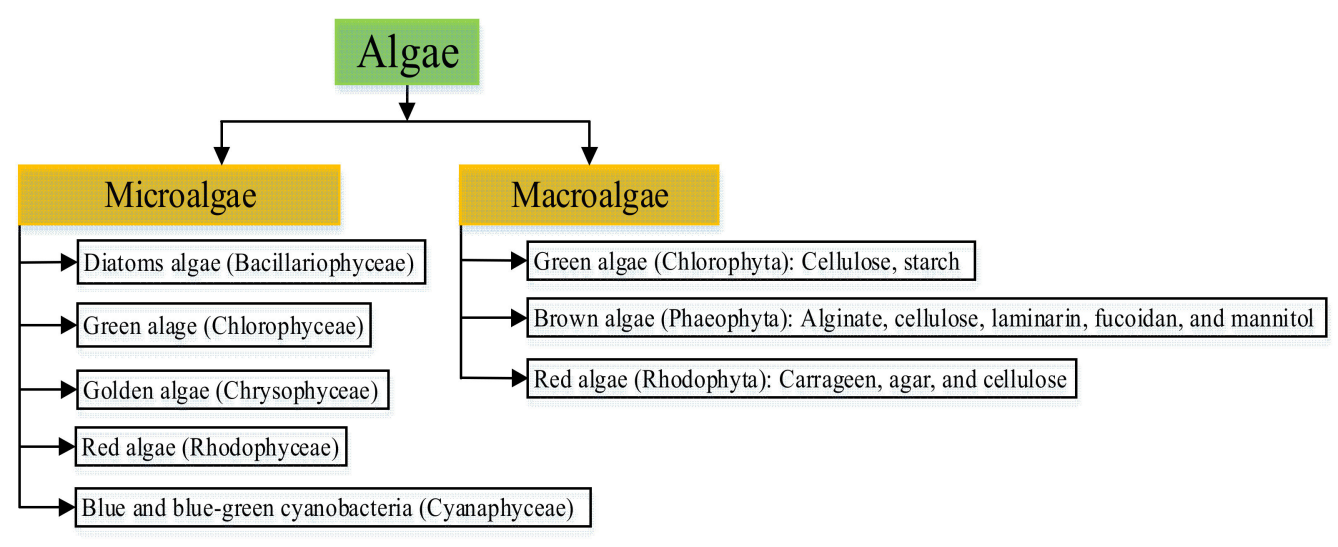

Figure 5. Classification of microalgae and macroalgae. Adapted from [33,72]. Developed by the authors.

Compared with other biomass feedstocks, algae feedstock is very competitive and offers many advantages, including the following:

i. The cultivation of algae consumes $\mathrm{CO}_{2}$, ensures carbon mitigation, and contributes to a carbon-neutral environment. The generation of $1 \mathrm{~g}$ algal biomass consumes $1.83 \mathrm{~g} \mathrm{CO}_{2}$ [73];

ii. Conversion of $\mathrm{CO}_{2}$ to algae-based biofuel; a ton of $\mathrm{CO}_{2}$ can be converted to between 55 and 70 gallons of ethanol [74];

iii. It does not compete with fresh water since algae can be cultivated in wastewater [75,76];

iv. Non-utilization of physical and fertile land [76]; algae can be grown artificially without land [77];

v. No competition with food security; eliminates the food vs. fuel debate [78];

vi. Algae grow 20 to 30 times more rapidly compared to food crops [70,79];

vii. Algae-based biofuel is substantially compatible with traditional gasoline engines and no engine modifications are required [80,81];

viii. Algae biomass is easily converted into a variety of fuels (diesel, gasoline, jet fuel, aviation gas, biodiesel, bioethanol, etc.) [70,82];

ix. Algae biomass has high oil content and produces between 10 and 100 times more oil per acre compared with other traditional oil crops [83];

x. Cultivation of algae does not involve the application of herbicides or pesticides [84]; xi. Microalgae allow wastewater bioremediation by removing $\mathrm{NH}_{4}, \mathrm{NO}_{3}$, and $\mathrm{PO}_{4}$ from municipal wastewater [85];

xii. Microalgal biomass can be utilized as food, animal feed, and fertilizer [70].

Despite these advantages, high production costs, highly technical infrastructure outlay, difficulties with integration into the existing system, and complex conversion techniques have restricted the sustainable commercial utilization of 3GF as feedstock $[33,86]$.

Fourth-Generation Feedstock

The challenges thrown up by the other generations of feedstock have encouraged researchers to look for biofuel from other sources. Fourth-generation feedstock (4GF) is genetically engineered [87]. Though 4GF is still in the experimental laboratory stage, it is being developed from the modification of algae. In this way, algae are being metabolically modified to have higher oil contents, increased carbon capture capability, and enhanced cultivation, harvesting, and fermentation procedures. Also, metabolic engineering is being harnessed to fast-track the growth rate and boost the lipid content of some species of algal biomass $[88,89]$. Since the oil contents of algae are species-dependent, some strains of algaenamely, Botryococcus braunii, Chaetoceros calcitrans, the Chlorella species, Isochrysis galbana, Nannochloropsis, Schizochytrium limacinum, and the Scenedesmus species-are being analyzed for their applicability and suitability $[90,91]$. Some investigations have been carried out on the application of nanotechnology to increase the efficiency and cost-effective production of 
algae-based biofuel. A novel approach referred to as "nanofarming" has been tipped to be invaluable for the acceleration of oil extraction from algal biomass by "milking algae", and it allows for the continuous utilization of biomass for a long period, up to 70 days [92,93].

\subsubsection{Classification Based on the Generation of Products}

Ever since the commencement of the utilization of biofuels (peanut oil to power the Rudolf Diesel Engine in 1900 [94] and vegetable oil to run ICEs in 1930 [95]), various parameters have been used for their classification. Researchers have classified biofuels into various generations. Naik et al. [96] and Akhlaghi et al. [97] classified biofuels into firstand second-generation biofuels. According to them, examples of first-generation biofuels (1GB) are bioethanol, biodiesel, and biogas, while vegetable oils, animal fats, etc., form second-generation biofuels (2GB). Other researchers, however, have classified biofuels into three generations, namely, 1GB, 2GB, and third-generation biofuels (3GB), which are produced from food crops (edible feedstocks), non-food crops (inedible feedstocks), and aquatic materials (cultivated feedstocks), respectively [98-100]. However, Algayyim et al. [101] and Rodionova et al. [102] grouped biofuels into primary biofuels and secondary biofuels. According to them, primary biofuels are those biomasses used without modifications, including wood, wood chips, grass, etc., and which are usually burned to generate heat for cooking and warming, while secondary biofuels are classified into 1GB, 2GB, and 3GB and produced from grains, lignocellulosic biomass, and algae, respectively. For their part, Noraini et al. [103], Mahjoub et al. [104], and Chowdhury and Loganathan [105] categorized biofuels into natural biofuels, 1GB, 2GB, and 3GB, which are sourced from firewood and animal waste and edible, lignocellulosic, and algae feedstocks, respectively. Also, Ziolkowska [106] and Fasahati et al. [107] classified biofuels into conventional biofuels (1GB) and advanced biofuels. According to them, conventional biofuels are ethanol and biodiesel produced from high-sugar-content crops, like corn, cereal, and sugarcane and biodiesel generated from waste oil, animal fats, soybean, rapeseed, palm oil, etc., while advanced biofuels are made up of cellulosic ethanol (2GB), algae biofuel (3GB), and next-generation biofuel (4GB).

Hao et al. [108] identified 1GB as being produced from food feedstocks; 1.5GB as generated from non-food and oil-bearing crops; $2 \mathrm{~GB}$ as sourced from cellulosic crops, waste cooking oil, and agricultural and forestry residues; and 3GB as made from algae. The majority of the recently published studies in the literature classify biofuels into $1 \mathrm{G}$ (biodiesel, bioethanol), 2G (bio-oil, biodiesel, bioalcohol, biohydrogen), 3G (biodiesel, biomethanol, bioethanol, jet fuel), and 4G (green biodiesel, biogasoline, green aviation fuels) [109-113]. Table 3 shows a summary of the classification of biofuels by various researchers. For this work, biofuels were categorized into five classifications: primary biofuels, 1GB, 2GB, 3GB, and 4GB. Table 4 shows the benefits and drawbacks of the adaptation and utilization of the primary biofuels and the four generations of biofuels.

Table 3. Classification of biofuels based on generation of products by various researchers.

\begin{tabular}{|c|c|c|c|}
\hline \multirow{2}{*}{ The Classifications } & \multicolumn{2}{|c|}{ Description } & \multirow{2}{*}{ Ref. } \\
\hline & Feedstocks & Examples & \\
\hline $2 \mathrm{~GB}$ & & Bioethanol, biodiesel, biogas & {$[96,97]$} \\
\hline $2 \mathrm{~GB}$ & & Vegetable oil, animal fats & \\
\hline $1 \mathrm{~GB}$ & Edible food crops & & [98-100,114-116] \\
\hline $2 \mathrm{~GB}$ & Inedible feedstocks & NA & \\
\hline $3 \mathrm{~GB}$ & Cultivated feedstocks & & \\
\hline Primary biofuels & Grass, wood, wood chips & & {$[101,102]$} \\
\hline \multicolumn{4}{|l|}{ Secondary biofuels } \\
\hline $1 \mathrm{~GB}$ & Grains, sugar & NA & \\
\hline $2 \mathrm{~GB}$ & Lignocellulosic biomass & & \\
\hline $3 \mathrm{~GB}$ & Algae, microbes & & \\
\hline
\end{tabular}


Table 3. Cont.

\begin{tabular}{|c|c|c|c|}
\hline \multirow{2}{*}{ The Classifications } & \multicolumn{2}{|c|}{ Description } & \multirow{2}{*}{ Ref. } \\
\hline & Feedstocks & Examples & \\
\hline Primary biofuels & Firewood, animal waste, landfill gas & \multirow{4}{*}{ NA } & \multirow[t]{4}{*}{ [103-105] } \\
\hline $1 \mathrm{~GB}$ & Edible feedstock & & \\
\hline $2 \mathrm{~GB}$ & Lignocellulosic feedstock & & \\
\hline $3 \mathrm{~GB}$ & Algae feedstock & & \\
\hline Conventional biofuels (1 GB) & $\begin{array}{l}\text { High-sugar-content crops, high-oleic } \\
\text { plants, animal fats }\end{array}$ & Ethanol, biodiesel & \multirow[t]{4}{*}[106,107]{} \\
\hline Cellulosic ethanol (2 GB) & $\begin{array}{l}\text { Energy crops, forest/park residues, seed } \\
\text { pods, leaves, stems, corn stovers }\end{array}$ & $\begin{array}{c}\text { Bioethanol, isopropanol, } \\
\text { butanol, isobutanol, farnesol }\end{array}$ & \\
\hline Algae biofuel (3 GB) & Algae & Biodiesel & \\
\hline Next generation biofuel (4 GB) & $\begin{array}{c}\text { Genetically and metabolically } \\
\text { engineered algae }\end{array}$ & Biosyngas & \\
\hline $1 \mathrm{~GB}$ & Food crops & \multirow{4}{*}{ NA } & \multirow[t]{4}{*}{ [108] } \\
\hline $1.5 \mathrm{~GB}$ & Non-food crops, oil-bearing crops & & \\
\hline $2 \mathrm{~GB}$ & $\begin{array}{l}\text { Agricultural and forest residues, waste } \\
\text { cooking oil }\end{array}$ & & \\
\hline $3 \mathrm{~GB}$ & Algae & & \\
\hline $1 \mathrm{~GB}$ & Animal waste, vegetable oil & $\begin{array}{c}\text { Bioalcohols, vegetable oil, } \\
\text { biodiesel, biomethanol, } \\
\text { biosyngas, biogas } \\
\text { Bioalcohols, bio-oil, bioDMF }\end{array}$ & \multirow[t]{4}{*}[109-113,117]{} \\
\hline $2 \mathrm{~GB}$ & NA & $\begin{array}{l}\text { bioFT, biodiesel, biohydrogen, } \\
\text { biomethanol }\end{array}$ & \\
\hline $3 \mathrm{~GB}$ & Algal biomass, waste vegetable oil & $\begin{array}{l}\text { Vegetable oil biodiesel, } \\
\text { bioethanol, bioethanol, } \\
\text { biomethanol, jet fuels }\end{array}$ & \\
\hline $4 \mathrm{~GB}$ & & $\begin{array}{l}\text { Green biodiesel, biogasoline, } \\
\text { green aviation fuels }\end{array}$ & \\
\hline Primary biofuel & $\begin{array}{l}\text { Grass, wood, wood chips, wood dust, } \\
\text { rice mill dust }\end{array}$ & $\begin{array}{l}\text { Wood chips, sawdust, } \\
\text { firewood, animal waste, forest } \\
\text { and crop residues, landfill gas } \\
\text { Bioalcohols, vegetable oil, }\end{array}$ & \multirow[t]{5}{*}{ The authors } \\
\hline $1 \mathrm{~GB}$ & Animal waste, edible oil, fats, and oil & $\begin{array}{l}\text { biodiesel, biomethanol, } \\
\text { biosyngas, biogas }\end{array}$ & \\
\hline $2 \mathrm{~GB}$ & $\begin{array}{l}\text { Wood and woody products, waste fats, } \\
\text { waste cooking oil, energy crops }\end{array}$ & $\begin{array}{c}\text { Bioalcohols, biooil, } \\
\text { biodimethylfuran, bioFT, } \\
\text { biodiesel, biohydrogen, } \\
\text { biomethanol }\end{array}$ & \\
\hline $3 \mathrm{~GB}$ & $\begin{array}{l}\text { Algae, high-sugar content crops, high } \\
\text { oleic plants, animal fats }\end{array}$ & $\begin{array}{l}\text { Vegetable oil biodiesel, } \\
\text { bioethanol, bioethanol, } \\
\text { biomethanol, jet fuels }\end{array}$ & \\
\hline $4 \mathrm{~GB}$ & Waste cooking oil, algal biomass & $\begin{array}{c}\text { Hydrogenated renewable } \\
\text { diesel, biogasoline, green } \\
\text { aviation fuel, vegetable oil, } \\
\text { biodiesel }\end{array}$ & \\
\hline
\end{tabular}

Compiled by the authors.

\section{Primary Biofuels}

The main feature of primary biofuels, also known as natural biofuel [103] or zerogeneration biofuel, is that they are used the way they occur without any modifications, alterations, processing, or pre-treatment. Examples of primary biofuels include firewood, wood chips, pellets, animal waste, forest and crop residues, and landfill gas. Notable areas of application of primary biofuels include cooking, household heating, brick kilns, drying, roasting, and electricity generation. This type of biofuel is readily available and its utilization does not require any special skill or infrastructure. However, their utilization is crude, compromises air quality, and may negatively impact the health of the user [118,119]. 


\section{First-Generation Biofuels}

The need to get a sustainable and viable alternative to finite energy sources gave rise to the development of 1GB. Major examples include biodiesel, biogas, bioalcohols, biosyngas, biomethanol, and bioethanol. Major feedstocks for the production of 1GB include edible (food) crops like corn, wheat, palm oil, soybeans, edible vegetable oil [120], rapeseed, Karanja, Moringa oleifeara, Jatropha curcas [121], corn, cereals, sugar cane, wood, grains, straw, charcoal, household waste, and dried manure [122]. Though 1GB is biodegradable and offers great environmental and social benefits, the food vs. fuel trade-off and extensive area and time required to grow the inedible feedstock are some of its drawbacks [123]. Also, the high cost of feedstock, which was found to consume over $70 \%$ of the generation cost, is discouraging [124-126].

\section{Second-Generation Biofuels}

Second-generation biofuels (2GB), which were developed as a solution to some of the drawbacks associated with 1GB, can be produced from inedible feedstocks like waste cooking oil [127], waste animal fats [128], recovered oil [129], and lignocellulosic biomass, like grass, wood, sugarcane bagasse, agricultural residues, forest residues, and municipal solid waste [130,131], as well as from bioethanol, biodiesel, biosyngass, biomass to liquid biodiesel conversion, bio-oil, biohydrogen, bioalcohols, biodimethylfuran, and bio-FischerTropsch [115,132]. The generation of 2GB does not affect the food chain and the cost of feedstocks is relatively low, but the production technologies are still complex and have not been commercialized yet $[98,133]$.

\section{Third-Generation Biofuels}

The challenges associated with 1GB and the 2GB gave rise to the development of 3GB, particularly with regard to feedstock selection. Algae, which is the major feedstock for $3 \mathrm{~GB}$, does not interfere with the food chain and requires no land or freshwater for cultivation, either naturally or artificially [134]. Other feedstocks for 3GB include yeast, fungi, and cyanobacteria, while examples of 3GB include bioethanol, vegetable oil, biodiesel, biomethanol, and jet fuels. In recent years, 3GB has attracted more investment, particularly in algae cultivation and conversion technologies [135].

\section{Fourth-Generation Biofuels}

4GB are produced from genetically or metabolically engineered feedstock from algae. Unlike 2GB and 3GB, the production of this generation of biofuels ensures sustainable production and catches $\mathrm{CO}_{2}$ emissions from oxygenated fuel combustion throughout the entire production progression [136]. The application of production technologies has drastically reduced the cost of production, making it economically competitive. Major examples of 4GB include hydrogenated renewable diesel, bio-gasoline, green aviation fuel, vegetable oil, and biodiesel. Table 4 shows the benefits and drawbacks of the adaptation and utilization of the primary biofuels and the four generations of biofuels. 
Table 4. Benefits and drawbacks of each generation of biofuels.

\begin{tabular}{|c|c|c|c|}
\hline Types of Biofuels & Benefits & Drawbacks & Ref. \\
\hline Primary & $\begin{array}{ll}\text { - } & \text { Readily available } \\
\text { - } & \text { Need no conversion technicalities } \\
\text { - } & \text { Co infrastructure for conversion } \\
\text { Costective }\end{array}$ & $\begin{array}{ll}\text { - } & \text { Combustion inefficiency } \\
\text { - } & \text { Limited applications and usage } \\
\text { Mostly in solid form }\end{array}$ & [137] \\
\hline First generation & $\begin{array}{ll}\text { - } & \text { Biodegradability } \\
\text { - } & \text { Readily available feedstock } \\
\text { - } & \text { Environmentally and socially beneficial } \\
\text { - } & \text { Ensure energy availability } \\
\text { - } & \text { Extensive applications } \\
\text { - } & \text { Easy blending with petroleum-based fuel } \\
\text { - } & \text { Safe handling and transportation }\end{array}$ & $\begin{array}{l}\text { - } \quad \text { Compete with food } \\
\text { - } \quad \text { Gead to the food vs. fuel debate } \\
\text { large arable land and time } \\
\text { Agricultural inputs like } \\
\text { fertilizer, herbicides, irrigation, } \\
\text { and manpower required } \\
\text { - Contribute the highest carbon } \\
\text { footprint in comparison with } \\
\text { other generations of biofuels }\end{array}$ & {$[138,139]$} \\
\hline
\end{tabular}

- Do not compete with the food chain

- Low cost of feedstock

- All parts of the seed, grains, and residues are useful as feedstock

- Lower land requirement

- Higher yield per hectare of land

- Energy security

- Environmentally beneficial

Second generation

- $\quad$ Production of other bio-based products apart from fuel

- Readily available feedstock in large quantities

- Availability of technology and infrastructure for feedstock generation

- Lower hygroscopic properties and less pipeline corrosion during transportation than other fuels
- $\quad$ Require substantial arable land to grow feedstock

- Conversion technologies not fully developed

- Complex processes are involved

- Dearth of research and technological breakthroughs

- Lack of commercially proven conversion technologies

- Agricultural and forest residues affect soil fertility, erosion, deforestation, and bush burning

- Lower conversion efficiency than fossil-based fuels
- Do not compete for land

- Do not affect food security

- Higher energy density per acre than conventional crops

- $\mathrm{CO}_{2}$ can be converted into algae-based biofuel

- Algae cultivation requires no arable land

- Algae entail no competition for freshwater

- Growing algae consume $\mathrm{CO}_{2}$ to produce biomass

Third generation artificially

- Very low cost of feedstock

- Renewability of bioengineered algae

- Energy security

- Contents are non-hazardous

- $\quad$ Algae used for other products and wastewater treatment

- High nutritional diversity of the feedstock

- High fuel diversity

- Highly compatible with conventional gasoline engines

- Difficulty in harvesting and processing

- $\quad$ Expensive processing cost

- Lack of research and technological breakthroughs

- Not commercially viable

- Production technologies not yet fully developed

- Conversion of feedstock to finished biofuel product needs novel technologies

- High costs of system infrastructure and integration

- Their combustion produces higher $\mathrm{NO}_{2}$ and $\mathrm{NO}$ than diesel

- High pour points and cloud points often result in fuel congealing and problematic initiation in cold weather 
Table 4. Cont.

\begin{tabular}{|c|c|c|c|}
\hline Types of Biofuels & Benefits & Drawbacks & Ref. \\
\hline Fourth generation & $\begin{array}{ll}\text { - } & \text { Carbon negative } \\
\text { - } & \text { High oil contents } \\
\text { - } & \text { Can generate synthetic materials for } \\
\text { - } & \text { Eossible biofuel production } \\
\text { - } & \text { Increased carbon entrapment ability } \\
\text { - } & \text { Can be genetically and metabolically } \\
\text { engineered } & \text { Improved cultivation, harvesting, and } \\
\text { - } & \text { fermentation processes }\end{array}$ & $\begin{array}{l}\text { - High cost } \\
\text { Technology still in the R\&D } \\
\text { stage } \\
\text { - Conversion of feedstock to } \\
\text { finished biofuel product needs } \\
\text { novel technologies } \\
\text { - The process requires high } \\
\text { energy inputs }\end{array}$ & {$[144,145]$} \\
\hline
\end{tabular}

Compiled by the authors.

\section{Transesterification as the Biofuel Conversion Technique}

Transesterification is a technology for the synthesis of biodiesel. The process of transesterification is easy to implement, cost-effective, easy to commercialize, and can be carried out at the household level. Although biodiesel can be generated through pyrolysis, microemulsion, transesterification, dilution, and superfluid methods, the transesterification process appears to have gained prominence among biodiesel producers. Table 5 compares the benefits and drawbacks of some biodiesel generation techniques. Indonesia, the USA, and Brazil dominated global biodiesel production and consumption in 2019 (Table 6) [146]. Due to its properties, including biodegradability, lower toxic emissions, improved cetane number, and better lubricity, the global consumption of biodiesel is projected to continue to increase. The search for sustainable fuels to replace environmentally degrading FB fuels, depleting oil reserves, and the unpredictability of the global oil market are expected to drive the continuous increase in the production and consumption of biodiesel in the foreseeable future. Table 7 compares the four generations of biodiesel in terms of their feedstocks, processing methods, benefits, and challenges.

Table 5. Advantages and disadvantages of various biodiesel production techniques.

\begin{tabular}{|c|c|c|}
\hline Production Techniques & Advantages & Disadvantages \\
\hline Pyrolysis & $\begin{array}{ll}- & \text { Easy process } \\
\text { - } & \text { Free from pollution }\end{array}$ & $\begin{array}{l}\text { - Involves elevated temperature } \\
\text { - } \quad \text { Costly apparatus required } \\
\text { - } \quad \text { Impure product }\end{array}$ \\
\hline Micro-emulsion & - Uncomplicated & - $\quad$ Reduced volatility and stability \\
\hline Dilution & - $\quad$ Easy process & $\begin{array}{l}\text { - Inchoate combustion } \\
\text { - } \quad \text { Carbon deposition in engines }\end{array}$ \\
\hline Transesterification & $\begin{array}{ll}\text { - } & \text { Simple process } \\
\text { - } & \text { Industrial-scale production } \\
\text { - } & \text { Properties of biodiesel produced } \\
& \text { comparable to PBD fuel }\end{array}$ & $\begin{array}{ll}\text { - } & \text { Multiple separation processes } \\
\text { - } & \text { High moisture and impurity levels } \\
\text { - } & \text { Costly catalysts } \\
\text { - } & \text { Generation of wastewater }\end{array}$ \\
\hline Superfluid methods & $\begin{array}{ll}\text { - } & \text { Short reaction time } \\
\text { - } & \text { No need for a catalyst } \\
\text { - } & \text { High conversion }\end{array}$ & $\begin{array}{l}\text { - High energy consumption } \\
\text { - } \quad \text { High cost of apparatus }\end{array}$ \\
\hline
\end{tabular}


Table 6. Top five countries for biodiesel production and consumption in 2019 [146].

\begin{tabular}{cccc}
\hline Biodiesel Production (Thousand Barrels per Day) & \multicolumn{2}{c}{ Biodiesel Consumption (Thousand Barrels per Day) } \\
\hline Countries & Volume & Countries & Volume \\
\hline Indonesia & 137.86 & US & 118.25 \\
US & 112.49 & Indonesia & 106.84 \\
Brazil & 99.95 & Brazil & 99.84 \\
Germany & 62.29 & Thailand & 30.02 \\
Argentina & 43.08 & China & 22.4 \\
\hline
\end{tabular}

Compiled by the authors.

Table 7. Comparison of the four generations of biodiesel $[147,148]$

\begin{tabular}{|c|c|c|c|c|}
\hline $\begin{array}{l}\text { Generation } \\
\text { of Biodiesel }\end{array}$ & Feedstock & $\begin{array}{l}\text { Processing } \\
\text { Technique }\end{array}$ & Benefits & Problems \\
\hline First & $\begin{array}{l}\text { Palm oil, sunflower } \\
\text { oil, soybean oil, corn } \\
\text { oil, canola oil }\end{array}$ & $\begin{array}{l}\text { Esterification and } \\
\text { transesterification of } \\
\text { oils, purification }\end{array}$ & $\begin{array}{ll}\text { - } & \text { Environmentally friendly } \\
\text { - } & \text { Commercially produced } \\
\text { - } & \text { Production parameters } \\
& \text { are attainable } \\
\text { - } & \text { Fairly cost-effective }\end{array}$ & $\begin{array}{ll}\text { - } & \text { Limited feedstock } \\
\text { - } & \text { Food vs. fuel debate } \\
\text { - } & \text { Require arable land for } \\
\text { cultivation } \\
\text { - } & \text { Contribute to } \\
\text { deforestation } \\
\text { - } & \text { Unsustainable } \\
\text { - } & \text { Use of pesticides and } \\
& \text { fertilizers poses a concern }\end{array}$ \\
\hline Second & $\begin{array}{l}\text { Non-edible oil, waste } \\
\text { cooking oil, waste } \\
\text { and recovered animal } \\
\text { fats }\end{array}$ & $\begin{array}{l}\text { Pre-treatment of } \\
\text { feedstock, } \\
\text { esterification and } \\
\text { transesterification of } \\
\text { feedstock, } \\
\text { purification } \\
\end{array}$ & $\begin{array}{ll}\text { - } & \text { No food-fuel conflict } \\
\text { - } & \text { Environmentally friendly } \\
\text { - } & \text { Cost-effective } \\
\text { Pesticides and fertilizers } \\
\text { not needed }\end{array}$ & $\begin{array}{ll}\text { - } & \text { Require pre-treatment } \\
\text { - } & \text { High cost of conversion } \\
\text { - } & \text { Arable land or forests } \\
\text { - } & \text { needed to grow } \\
\end{array}$ \\
\hline Third & $\begin{array}{l}\text { Microalgae, } \\
\text { Macroalgae }\end{array}$ & $\begin{array}{l}\text { Algae cultivation, } \\
\text { harvesting, oil } \\
\text { extraction, } \\
\text { transesterification }\end{array}$ & $\begin{array}{ll}\text { - } & \text { No food-fuel conflict } \\
\text { - } & \text { High yield } \\
\text { - } & \text { Arable land not needed } \\
\text { - } & \text { Easy conversion } \\
& \text { Environmentally friendly }\end{array}$ & $\begin{array}{l}\text { - Underdeveloped } \\
\text { technology } \\
\text { - } \quad \begin{array}{l}\text { Large initial cost of } \\
\text { cultivation }\end{array} \\
\text { - } \quad \begin{array}{l}\text { Complicated and } \\
\text { expensive harvesting }\end{array}\end{array}$ \\
\hline Fourth & Microalgae, Microbes & $\begin{array}{c}\text { Metabolic } \\
\text { engineering of algae, } \\
\text { cultivation, } \\
\text { harvesting, } \\
\text { transesterification }\end{array}$ & $\begin{array}{ll}\text { - } & \text { No food-fuel conflict } \\
\text { - } & \text { High yield } \\
\text { - } & \text { High production rate } \\
\text { - } & \text { Non-arable land needed } \\
\text { - } & \text { for cultivation } \\
\text { - } & \text { larghibitive cost for } \\
\text { - } & \text { Easy conve cultivation } \\
\end{array}$ & $\begin{array}{l}\text { - Prohibitive preliminary } \\
\text { investment } \\
\text { - } \quad \begin{array}{l}\text { Research still at the } \\
\text { preliminary stage }\end{array} \\
\text { - } \quad \begin{array}{l}\text { High initial cost for } \\
\text { extensive cultivation }\end{array} \\
\text { - } \quad \begin{array}{l}\text { Harvesting of microalgae } \\
\text { and microbes is } \\
\text { expensive }\end{array}\end{array}$ \\
\hline
\end{tabular}

Compiled by the authors.

Transesterification is a chemical process in which renewable biological raw materials react chemically with alcohol with or without a catalyst. At the end of the reaction, a mixture of biodiesel, also commonly referred to as fatty acid methyl ester (FAME), and glycerol, an equally high-value co-product, is produced. A non-catalytic transesterification process is one in which no catalyst is involved in the conversion process. The non-catalytic transesterification process is believed to occur within a pressure range of 45 bar to 65 bar, a temperature range of $200{ }^{\circ} \mathrm{C}$ to $400{ }^{\circ} \mathrm{C}$, and in the presence of alcohol [149]. Compared with the catalytic transesterification process, the supercritical transesterification process 
has been found to take place in a shorter time and is a simplified purification process, as removal of a catalyst is not needed. However, the non-catalytic transesterification process is limited to batch processes and requires high temperature and pressurized reaction vessels, so it has a high energy cost. A transesterification reaction can be catalyzed by homogeneous catalysts $(\mathrm{NaOH}, \mathrm{KOH})$, heterogeneous catalysts $(\mathrm{CaO}, \mathrm{Mg} / \mathrm{Zr}, \mathrm{Mg}-\mathrm{Al})$, or a bio-based catalyst (enzyme), like lipase. Table 8 compares the merits and demerits of homogeneous, heterogeneous, and bio-based catalysts for the transesterification process.

Table 8. Merits and demerits of various catalysts for the transesterification process [150-152].

\begin{tabular}{|c|c|c|c|}
\hline Type of Catalyst & Example & Pros & Cons \\
\hline Homogeneous & $\begin{array}{c}\mathrm{NaOH}, \mathrm{KOH}, \mathrm{CH}_{3} \mathrm{ONa}, \\
\mathrm{H}_{2} \mathrm{SO}_{4}\end{array}$ & $\begin{array}{ll}\text { - } & \text { Faster reaction } \\
\text { - } & \text { Reactions occur at mild } \\
\text { - } & \text { Unperatures } \\
\text { - } & \text { moisture content } \\
\text { - Application to esterification } \\
\text { and transesterification } \\
\text { processes } \\
\text { - } \quad \text { Favor superior kinetics }\end{array}$ & $\begin{array}{ll}\text { - } & \text { Formation of soap } \\
\text { - } & \text { Low yield } \\
\text { - } & \text { Large wastewater generation } \\
\text { - } & \text { Slow reaction } \\
\text { - } & \text { Lead to corrosiveness }\end{array}$ \\
\hline Heterogeneous & $\begin{array}{c}\mathrm{CaO}, \mathrm{Mg} / \mathrm{Zr}, \mathrm{Mg}-\mathrm{Al} \\
\text { hydrotalcite, } \mathrm{ZnO} / \mathrm{KF}, \\
\mathrm{ZnO} / \mathrm{Ba}, \mathrm{Na} / \mathrm{BaO}, \\
\mathrm{K}_{2} \mathrm{CO}_{3} \text {-supported } \mathrm{MgO}, \\
\mathrm{Al}_{2} \mathrm{O}_{3} / \mathrm{ZrO}_{2} / \mathrm{WO}_{3}, \\
\mathrm{Al}_{2} \mathrm{O}_{3} / \mathrm{KNO}_{3} \text {, solid } \\
\text { vanadium phosphate, } \\
\mathrm{Fe}-\mathrm{Zn} \text { double metal } \\
\text { cyanide complex }\end{array}$ & $\begin{array}{ll}\text { - } & \text { Easy separation } \\
\text { - } & \text { Reusability and regeneration } \\
& \text { conger lifetime of the } \\
\text { - } & \text { Fewer waste and disposal } \\
\text { - } & \text { problems } \\
\text { - } & \text { Alkaline catalysts have } \\
\text { - } & \text { higher selectivity } \\
\text { - } & \text { and recyclable } \\
\text { - Comparatively cheap }\end{array}$ & 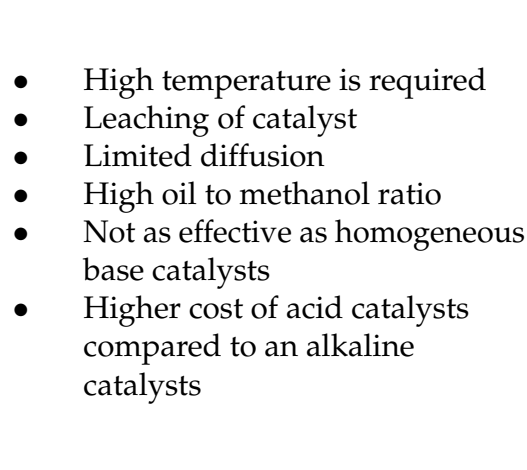 \\
\hline Bio-based (enzyme) & Lipase, Candida antaractia & $\begin{array}{l}\text { - } \quad \text { Require less purification } \\
\text { - } \quad \text { Occursat low temperature } \\
\text { Products are completely } \\
\text { bio-based }\end{array}$ & $\begin{array}{ll}\text { - } & \text { Expensive } \\
-\quad & \text { Reduced reaction rate } \\
\text { - } & \text { Inactive enzyme when exposed } \\
\text { to alcohol }\end{array}$ \\
\hline
\end{tabular}

Compiled by the authors.

The biodiesel yield and oil conversion rate are influenced by various process parameters. These parametric conditions include the FFA value, reaction temperature, reaction time, alcohol to oil ratio, catalyst to oil ratio, catalyst type, catalyst concentration, catalyst particle size, and mixing or agitation rate [149]. For example, the choice of methanol as alcohol means the reaction temperature must be less than $60^{\circ} \mathrm{C}$. Also, if the FFA value of the feedstock is greater the $1 \mathrm{mgKOH} / \mathrm{g}$, a two-step procedure consisting of acid-catalyzed esterification (Figure 6) and alkaline-catalyzed transesterification reactions is adopted. Generally, under varying catalysts and feedstocks, the process parameters for optimal production of biodiesel agree with the established standards, particularly the ASTM D6751 and EN 14214 standards. Figure 7 depicts the combination of the three steps involved in transesterification.

The choice of alcohol determines the nomenclature of the resulting ester. Commonly used alcohols include methanol, ethanol, propanol, isopropanol, and butanol. Though methanol and ethanol are the most frequently used alcohols for biodiesel synthesis, methanol is often selected due to its physical and chemical benefits. Methanol dissolves easily in homogeneous catalysts, particularly $\mathrm{NaOH}$, and reacts more easily with triglycerides than ethanol [153]. When bioethanol is used as the alcohol, completely bio-based 
biodiesel is produced. If methanol is used as the alcohol, the reaction gives FAME, while fatty acid ethyl ester results from the use of ethanol as the alcohol [154]. The number of steps involved in the transesterification process can be determined based on the amount of free fatty acids (FFAs). If the FFA value of the feedstock is above $1 \mathrm{mgKOH} / \mathrm{g}$, transesterification is preceded by the esterification process. Esterification is a single-step process in which tetra oxo sulphate IV acid is used as a homogenous catalyst to bring the FFA value to less than $1 \mathrm{mgKOH} / \mathrm{g}$. If the FFA value is lower than $1 \mathrm{mgKOH} / \mathrm{g}$, a single-step transesterification process is adopted. Due to the low quality of some of the feedstocks, especially waste cooking oil, waste animal fats, recovered fats, and grease, pretreatment processes are required before transesterification $[155,156]$.

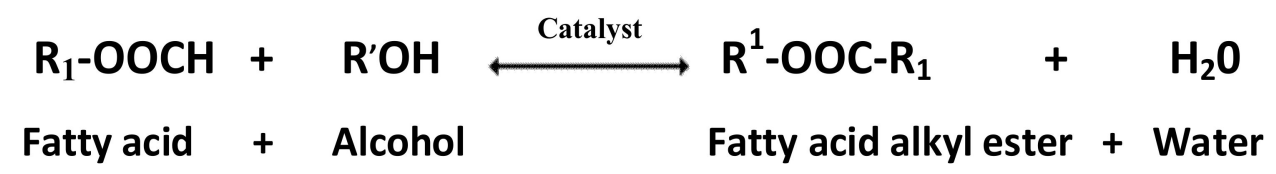

Figure 6. Esterification reaction [157].<smiles>[R]C(=O)OC[C@H](CO)OC([R])=O</smiles>

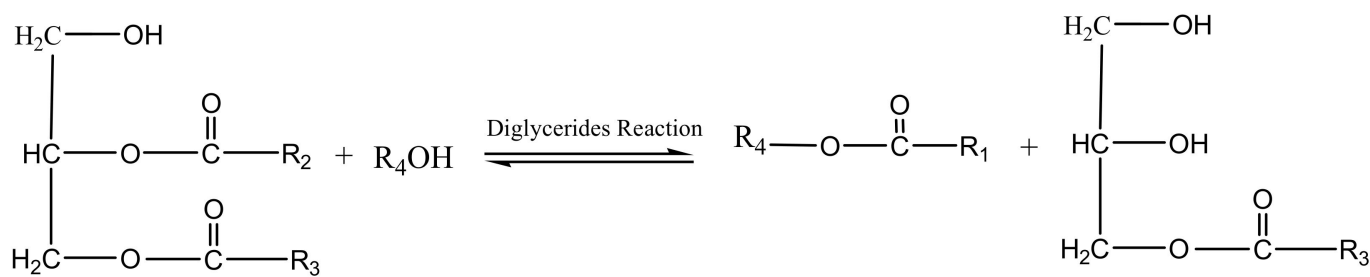

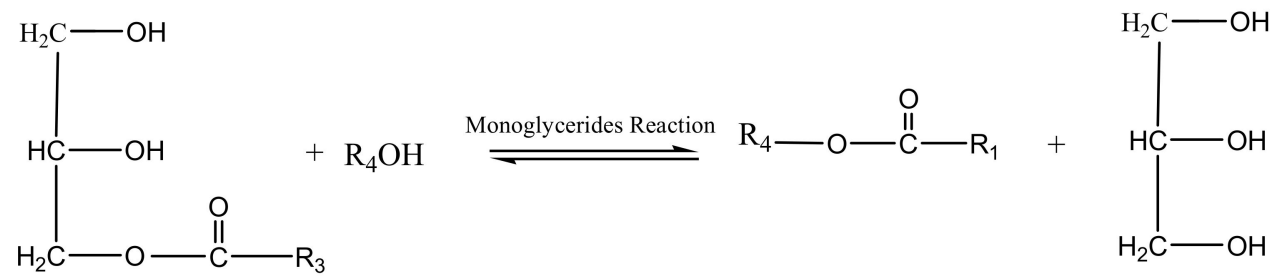

Figure 7. Three-step equation for the transesterification reaction [158,159].

\section{Biofuel Production from Waste}

Cost is one of the major factors inhibiting the adaptation of biofuels as sustainable transportation fuels. For example, the pump price of biodiesel is higher than that of fossilbased diesel fuel. The cost of feedstock is a major component of the cost of production. The cost of feedstock accounts for about 70-95\%, 36-56\%, and 49-56\% of the overall production costs of biodiesel, bioethanol, and biogas, respectively $[125,160,161]$. The use of waste materials as feedstock is a viable cost-reduction strategy for biofuel production. The use of edible vegetable oils that have been previously used for frying in households and restaurants has become popular in recent years. These used vegetable oils are collected 
from users at the point of disposal. Consumption of WCO has serious health implications and its inappropriate disposal block drains and pollutes terrestrial and aquatic habitats.

In separate studies, Pugazhendhi et al. [21], Mohadesi et al. [162], and Naeem et al. [163] produced biodiesel from WCO with the transesterification process and reported biodiesel yields of $90 \%, 97.4 \%$, and $98 \%$ respectively. The transesterification process was also used to convert waste beef tallow from tanneries and slaughterhouses [164], waste chicken fat chicken from chicken processing units [165], and swine fat from meat processing companies [166] to quality biodiesel at moderate operating conditions. Kitchen, garden, and food waste were used for bioethanol production through fermentation and the residue was subjected to AD for biogas production [167-170]. Waste activated sludge, waste peach pulp, and waste tires were also used as feedstocks in studies on the production of biohydrogen that explored fermentation and gasification technologies [171-173]. Other forms of waste have also been converted to biofuels for ICE applications. The conversion of this waste to biofuels is cost-effective and ensures waste minimization and appropriate waste disposal, sanitation, and waste management. Table 9 shows some of the recently investigations on the conversion of waste to biodiesel, biogas, bioethanol, and hydrogen.

Table 9. Recent examples of conversion of waste to biofuels.

\begin{tabular}{|c|c|c|c|c|c|}
\hline Feedstock & Process & Product & Reasons for the Adoption & Remarks & Ref. \\
\hline WCO & Transesterification & Biodiesel & $\begin{array}{l}\text { Conversion of waste } \\
\text { food to fuel } \\
\text { - } \quad \text { Low-cost feedstock } \\
\text { Means of disposal of } \\
\text { used oil } \\
\text { - Feedstock does not affect } \\
\text { food security }\end{array}$ & $\begin{array}{l}\text { - } \quad 90 \% \text { biodiesel yield } \\
\text { - } \quad \text { Product complies with } \\
\text { ASTM standards } \\
\text { - Activation energy of } \\
57.82 \mathrm{~kJ} / \mathrm{mol}\end{array}$ & [21] \\
\hline WCO & Transesterification & Biodiesel & $\begin{array}{l}\text { - Conversion of waste } \\
\text { food to fuel } \\
\text { - } \quad \text { Low-cost feedstock } \\
\text { - Means of disposal of } \\
\text { used oil } \\
\text { - } \quad \begin{array}{l}\text { Feedstock does not affect } \\
\text { food security }\end{array}\end{array}$ & $\begin{array}{ll}\text { - } & 97.4 \% \text { biodiesel yield } \\
\text { - } & \text { Biodiesel purity } \\
\text { of } 97.47 \% \\
\text { - } \quad \begin{array}{l}\text { Product complies with } \\
\text { standards }\end{array}\end{array}$ & [162] \\
\hline WCO & Transesterification & Biodiesel & $\begin{array}{l}\text { Conversion of waste } \\
\text { food to fuel } \\
\text { - } \quad \text { Low-cost feedstock } \\
\text { Means of disposal of } \\
\text { used oil } \\
\text { - } \\
\text { Feedstock does not affect } \\
\text { food security }\end{array}$ & $\begin{array}{l}\text { - } \quad 98 \% \text { biodiesel yield } \\
\text { - } \quad \text { Activation energy of } \\
21.65 \mathrm{~kJ} / \mathrm{mol} \\
\text { - } \quad \text { Product complies with } \\
\text { ASTM standards }\end{array}$ & [163] \\
\hline $\begin{array}{c}\text { Waste } \\
\text { soybean oil }\end{array}$ & Transesterification & Biodiesel & $\begin{array}{l}\text { - } \quad \text { Low-cost feedstock } \\
\text { The feedstock is } \\
\text { readily available } \\
\text { No conflict with the } \\
\text { food chain }\end{array}$ & $\begin{array}{l}\text { - } \quad 98 \% \text { biodiesel yield } \\
\text { - } \quad \text { Product complies } \\
\text { with standards }\end{array}$ & [164] \\
\hline
\end{tabular}


Table 9. Cont.

\begin{tabular}{|c|c|c|c|c|c|}
\hline Feedstock & Process & Product & Reasons for the Adoption & Remarks & Ref. \\
\hline $\begin{array}{l}\text { Waste beef } \\
\text { tallow }\end{array}$ & Transesterification & Biodiesel & $\begin{array}{ll}\text { - } & \text { Low-cost feedstock } \\
\text { - } & \text { Ease of conversion } \\
\text { - } & \text { Cost-effective process } \\
\text { - } & \text { Inedible feedstock }\end{array}$ & $\begin{array}{l}\text { - } \quad \text { Biodiesel yield of } 74.5 \% \\
\text { The product meets } \\
\text { ASTM and } \\
\text { EN standards. }\end{array}$ & [164] \\
\hline $\begin{array}{l}\text { Waste } \\
\text { chicken fat }\end{array}$ & Transesterification & Biodiesel & $\begin{array}{l}\text { - Low-cost feedstock } \\
\text { - } \quad \text { Avenue for conversion of } \\
\text { waste to fuel } \\
\text { No conflict with the } \\
\text { food chain }\end{array}$ & $\begin{array}{l}\text { - } \quad \text { Biodiesel yield of } 90.2 \% \text {. } \\
\text { The product meets the } \\
\text { D6751-10 and EN } 14214 \\
\text { standards }\end{array}$ & [165] \\
\hline Swine fat & Transesterification & Biodiesel & $\begin{array}{ll}\text { - } & \text { Availability } \\
\text { - } & \text { Low cost } \\
\text { - } & \text { High fatty acid content } \\
\text { - } & \text { Inedible feedstock }\end{array}$ & $\begin{array}{l}\text { Biodiesel of } 98 \% \text { purity } \\
\text { was produced } \\
\text { The product meets the } \\
\text { regulatory standard } \\
\text { - } \quad \begin{array}{l}\text { Reaction time was } \\
\text { reduced by } 63.3 \%\end{array}\end{array}$ & [166] \\
\hline $\begin{array}{l}\text { Kitchen } \\
\text { and garden } \\
\text { waste }\end{array}$ & Fermentation & Ethanol & $\begin{array}{l}\text { - Conversion of waste } \\
\text { to ethanol } \\
\text { - Waste minimization and } \\
\text { conversion strategy } \\
\text { Moderate and } \\
\text { cost-effective process } \\
\text { parameters }\end{array}$ & $\begin{array}{ll}\text { - } & \text { Ethanol yield of } \\
\text { - } & \text { Low-cost ethanol } \\
\text { powieved } \\
\text { - } & \text { High conversion rate } \\
\text { - } & \text { High purity of ethanol } \\
\text { produced }\end{array}$ & [167] \\
\hline $\begin{array}{l}\text { Kitchen } \\
\text { and garden } \\
\text { waste } \\
\text { residue }\end{array}$ & $\begin{array}{l}\text { Anaerobic } \\
\text { digestion }\end{array}$ & Biogas & $\begin{array}{l}\text { - Conversion of waste to } \\
\text { methane } \\
\text { - Waste minimization and } \\
\text { conversion strategy } \\
\text { Moderate and } \\
\text { cost-effective process } \\
\text { parameters }\end{array}$ & 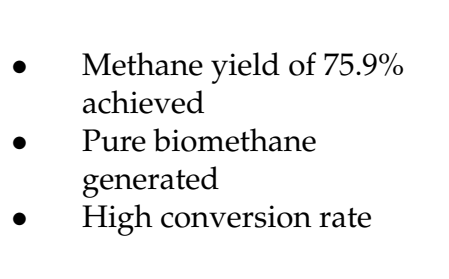 & [167] \\
\hline $\begin{array}{l}\text { Pineapple } \\
\text { fruit peel } \\
\text { waste }\end{array}$ & Fermentation & Bioethanol & $\begin{array}{l}\text { - Low-cost feedstock } \\
\text { - } \quad \text { Avenue for conversion of } \\
\text { food waste to fuel } \\
\text { No conflict with the food } \\
\text { chain } \\
\text { - Avenue for waste } \\
\text { minimization and } \\
\text { conversion }\end{array}$ & $\begin{array}{l}\text { - } \quad \text { Bioethanol yield of } \\
5.98 \pm 1.01 \mathrm{~g} / \mathrm{L} \text { achieved }\end{array}$ & [168] \\
\hline $\begin{array}{l}\text { Cucumber } \\
\text { residue }\end{array}$ & $\begin{array}{l}\text { Anaerobic } \\
\text { digestion }\end{array}$ & Methane & $\begin{array}{l}\text { Easy conversion of waste } \\
\text { to methane } \\
\text { - Waste minimization and } \\
\text { conversion strategy }\end{array}$ & $\begin{array}{l}\text { - } \quad \text { High methane yield of } \\
305.4 \mathrm{~mL} / \mathrm{g} \text { VS }\end{array}$ & [169] \\
\hline Food waste & $\begin{array}{l}\text { Anaerobic } \\
\text { digestion }\end{array}$ & Methane & $\begin{array}{l}\text { - Cheap and robust waste } \\
\text { conversion strategy } \\
\text { - } \quad \text { Manure as a byproduct }\end{array}$ & $\begin{array}{l}\text { - Methane yield of } \\
450-550 \mathrm{~mL} / \mathrm{g} \text { VS } \\
\text { achieved } \\
\text { Pure biomethane } \\
\text { generated }\end{array}$ & [170] \\
\hline
\end{tabular}


Table 9. Cont.

\begin{tabular}{|c|c|c|c|c|c|}
\hline Feedstock & Process & Product & Reasons for the Adoption & Remarks & Ref. \\
\hline $\begin{array}{l}\text { Waste } \\
\text { activated } \\
\text { sludge }\end{array}$ & Fermentation & Hydrogen & $\begin{array}{l}\text { - } \quad \text { Easy conversion process } \\
\text { - } \quad \text { Mild process parameters } \\
\left(70^{\circ} \mathrm{C}, 60 \mathrm{~min}\right)\end{array}$ & $\begin{array}{l}\text { - High yield of hydrogen } \\
\text { Economically attractive } \\
\text { and practically feasible } \\
\text { process }\end{array}$ & [171] \\
\hline $\begin{array}{c}\text { Waste } \\
\text { peach pulp }\end{array}$ & Fermentation & Biohydrogen & $\begin{array}{l}\text { - Avenue for cheap } \\
\text { conversion of waste to } \\
\text { fuel }\end{array}$ & $\begin{array}{l}\text { - High hydrogen } \\
\text { formation rate and yield }\end{array}$ & [172] \\
\hline Waste tires & Gasification & Hydrogen & $\begin{array}{l}\text { - Assistance in the } \\
\text { utilization of waste tires } \\
\text { - Cheap feedstock for } \\
\text { hydrogen production }\end{array}$ & $\begin{array}{ll}\text { - } & \text { Energy efficiency of } \\
& 55.01 \% \\
\text { - } & \text { Exergy efficiency of } \\
& 52.31 \% \\
\text { - } & \text { High hydrogen } \\
\text { production rate }\end{array}$ & [173] \\
\hline
\end{tabular}

$\mathrm{WCO}=$ waste cooking oil, ASTM = American Society for Testing and Materials, EN = European standard.

\section{Biofuel as Internal Combustion Engine Fuels}

Transportation is one of the necessities of life and a major contributor to the socioeconomic growth of countries. The ease of the movement of goods and services is one of the measures of the quality of life of individuals. Governments across jurisdictions devote significant efforts and resources to ensure affordable and safe transportation services. The transportation sector consumes over $90 \%$ of the total FB fuel products and over $25 \%$ of global energy $[174,175]$. The proportion of the total energy used for on-road transport is projected to increase from the present $28 \%$ to $50 \%$ by 2030 and further to $80 \%$ by 2050 [176]. The total energy consumption in the transport sector was 110 million TJ in 2015 including passenger vehicles (cars and bikes), buses, air, passenger rail, and air freight. Heavy trucks, light trucks, and marine transport jointly consume $35 \%$ of the transportation sector energy, as shown in Figure $8[177,178]$. The 129 billion liters of liquid biofuel used in 2016 is projected to rise to 652 billion liters by 2050, while about 180 billion liters of biodiesel will be needed in the transport sector in 2050, as shown in Figure 9 [179].

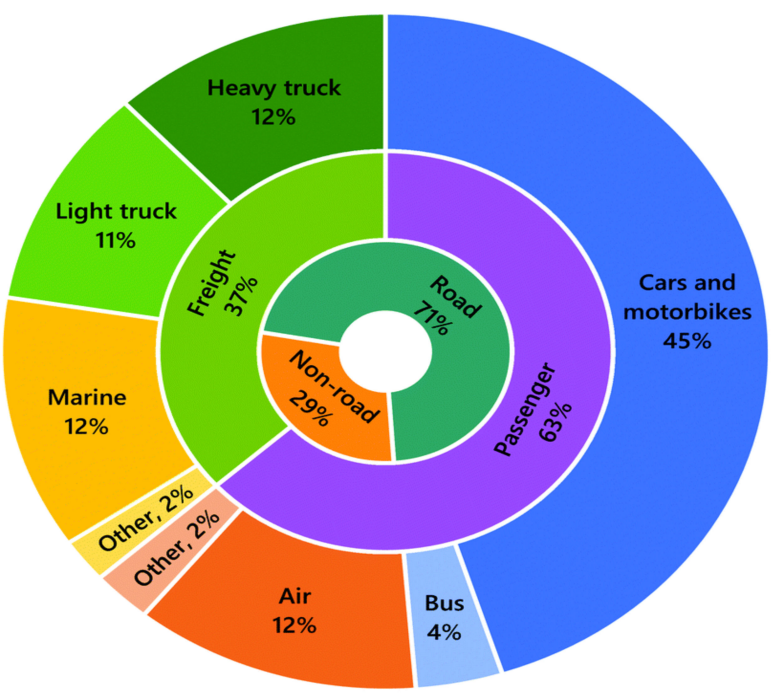

Figure 8. Summary of global energy utilization in the transport sector in 2015 [177,178]. 


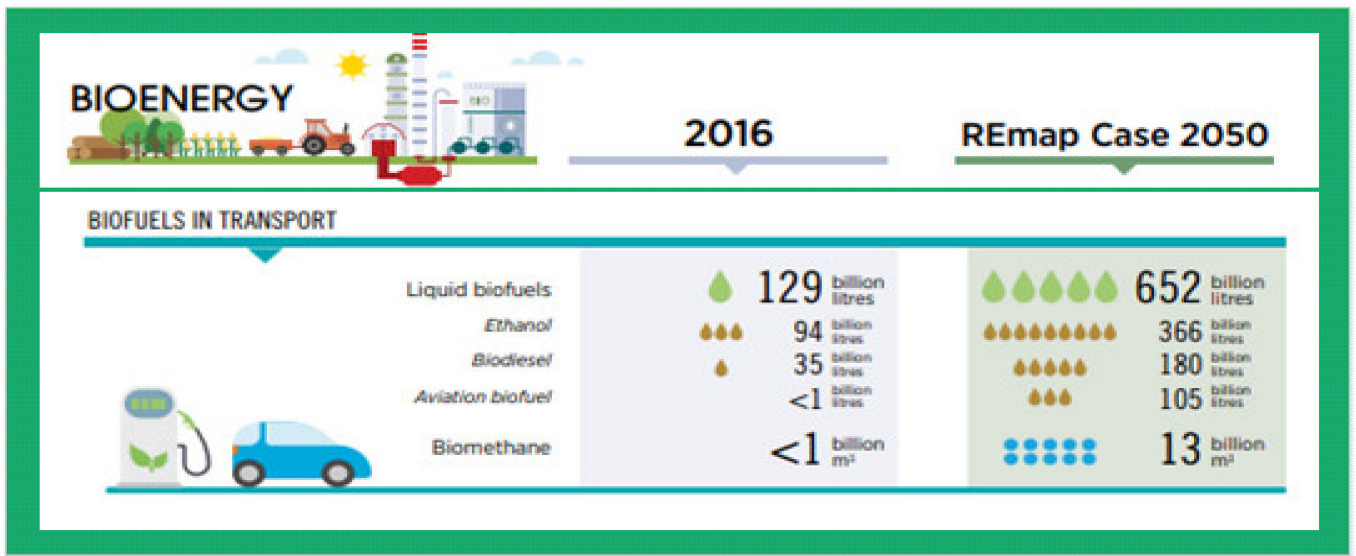

Figure 9. Biofuel in the transport sector, 2016 and 2050 scenarios. Adapted from [179]. Developed by the authors.

Currently, there are about 1.2 billion vehicles on the road and this number is projected to rise to 2 billion cars by 2035 and further to 2.5 billion cars by 2050 [180,181]. If these cars depend on FB fuels, the attendant environmental effects will be disastrous and the cost unimaginable. Biofuel, hydrogen, and electric vehicles (EVs) are the three options for low-carbon transport systems. Though hydrogen and EVs avoid land use and impact air quality, ICEs will still be in use in most developing countries for the foreseeable future [182].

Liquid and gaseous biofuels are used to power ICEs. However, liquid biofuels are preferred over gaseous biofuels for vehicle propulsion. This is because liquid biofuels have a higher energy density than gaseous fuels, thereby allowing vehicles to possess immense range. Table 10 shows the energy stored per liter for petrol or petroleum-based gasoline (PBG) fuel, PBD fuel, and some biofuels. Gaseous fuels require pressurized tanks and they must be larger for an equal quantity of stored energy compared to liquid fuels. Also, refueling is more straightforward, easier, and faster with liquid fuels than gaseous fuels.

Table 10. Energy stored per liter of fuel [183].

\begin{tabular}{cc}
\hline Fuel & Stored Energy (MJ) \\
\hline Diesel & 36 \\
Gasoline & 33 \\
Biodiesel & 33 \\
Methanol & 16 \\
Ethanol & 21 \\
Liquid $\mathrm{H}_{2}\left(\right.$ at $\left.-253^{\circ} \mathrm{C}\right)$ & 8.5 \\
Compressed $\mathrm{H}_{2}($ at 250 bar $)$ & 2.5 \\
\hline
\end{tabular}

The use of a fuel as an ICE fuel depends on its properties. Table 11 shows some properties of diesel, gasoline, and some liquid and gaseous biofuels. The density is calculated as the mass per unit volume. The density of a fuel is determined by the mass of fuel entering the combustion chamber and the air/fuel ratio. A higher heating value (HHV) is the quantity of heat realized when a unit amount of fuel is completely combusted. $\mathrm{HHV}$ is obtained by cooling the products of combustion, leading to the formation of water vapor [184,185]. The HHV of fuel is directly proportional to the quantity of carbon in the fuel and the ratio of $\mathrm{C}-\mathrm{H}$ to $\mathrm{O}_{2}-\mathrm{N}_{2}$. Conversely, the lower heating value (LHV) of a fuel is the energy content of the fuel. The distinction between the HHV and LHV is a measure of the heat content of the condensed water vapor formed during combustion. The density and heating values determine the energy available in the fuel, along with the volume and mass. The cetane number $(\mathrm{CN})$ is a function of the amount of time lag between the fuel injection and auto-ignition [184]. The CN is used to classify PBD fuel and measures the ability of the fuel to self-ignite. Fuels with high CNs are good for CI engines because this ensures that the engine enjoys an excellent start and runs smoothly, particularly during 
cold weather. A low $\mathrm{CN}$ tends to result in incomplete combustion and exacerbates the emission of dangerous gases [186].

Kinematic viscosity is a property that influences the atomization properties, the size of the droplets and spray penetration, and the potential of atomized fuel. Fuels with high kinematic viscosity values suffer from poor fuel atomization during the spray and increased wear rate of the engine, pump parts, and injectors, which jointly result in poor combustion and increased emissions [187]. Ethanol and dimethyl ether have lower viscosity values and are more capable of making fine droplet sprays than PBD fuel. The flash point measures the temperature at which sufficient water vapor is released to generate the appropriate quantity of the water vapor-air mixture and relates to the safe handling and transportation of the fuel. A fuel with a flashpoint below $38^{\circ} \mathrm{C}\left(100^{\circ} \mathrm{F}\right)$ is considered flammable [188]. The latent heat of vaporization quantifies the degree of coolness experienced as a result of fuel evaporation. The stoichiometric air/fuel ratio (A/F) of a fuel is a measure of the hydrogen/carbon ratio of the fuel and the quantity of oxygen contained in the compound [189]. The research octane number (RON) is also used to classify PBG fuel and measures the ability of the fuel to self-ignite. High RONs are good for spark ignition (SI) engines [190]. The Reid vapor pressure is also a critical fuel fingerprint for measuring the behavior of fuel, particularly when the SI engine is appropriately carbureted and fueled. The ease with which the spark ignites the air/fuel mixture indicates the flammability limit of the fuel. Hydrogen fuel, a form of renewable fuel, is reputed to possess the highest flammability limit. 
Table 11. Physical and chemical properties of some transportation fuels [183,191-194].

\begin{tabular}{|c|c|c|c|c|c|c|c|c|c|}
\hline Property & PBG & PBD & Methanol & Ethanol & DME & Biogas & Hydrogen & Biodiesel & F-T Diesel \\
\hline Chemical formula & $\mathrm{C}_{\mathrm{n}} \mathrm{H}_{1.87 \mathrm{n}}$ & $\mathrm{C}_{\mathrm{n}} \mathrm{H}_{1.8 \mathrm{n}}$ & $\mathrm{CH}_{3} \mathrm{OH}$ & $\mathrm{C}_{2} \mathrm{H}_{5} \mathrm{OH}$ & $\mathrm{CH}_{3} \mathrm{OCH}_{3}$ & $\mathrm{CH}_{4}$ & $\mathrm{H}_{2}$ & $\mathrm{C}_{15} \mathrm{H}_{31} \mathrm{CO}_{2} \mathrm{CH}_{3}$ & $\mathrm{C}_{9}$ to $\mathrm{C}_{20}$ \\
\hline Density $\left(\mathrm{kg} / \mathrm{m}^{3}\right)$ & $720-780$ & $820-870$ & 800 & 790 & 667 & - & 70 & $850-885$ & $774-782$ \\
\hline Kinetic viscosity at $40^{\circ} \mathrm{C}(\mathrm{cSt})$ & 0.7 & $2.0-3.5$ & 0.75 & 1.5 & 0.18 & - & - & 4.43 & 2-4.5 \\
\hline Self-ignition temperature $\left({ }^{\circ} \mathrm{C}\right)$ & $260^{a}$ & $210^{\mathrm{a}}$ & 470 & 365 & 320 & 580 & 500 & 220 & 315 \\
\hline Lower heating value $(\mathrm{MJ} / \mathrm{kg})$ & 44 & 43 & 19.7 & 28.6 & 28.2 & 24 & 120 & 37 & $43.5^{\mathrm{a}}$ \\
\hline Lower heating value (liquid) (MJ/L) & 33 & 36 & 16 & 21 & 19 & - & 8.5 & 33 & - \\
\hline Higher heating value (mixture) $(\mathrm{kJ} / \mathrm{kg})$ & 3.8 & 3.9 & 3.5 & - & 3.4 & 3.1 & 2.0 & - & - \\
\hline Boiling temperature $\left({ }^{\circ} \mathrm{C}\right)$ & $25-210$ & $180-360$ & 65 & 78 & -25 & -162 & -253 & $250-350$ & 157.6 \\
\hline Reid vapor pressure at $38^{\circ} \mathrm{C}(\mathrm{kPa})$ & $55-100$ & $<1.5$ & 32 & 16 & 800 & - & - & - & - \\
\hline Stoichiometric A/F ratio & $14.5^{\mathrm{a}}$ & $14^{\mathrm{a}}$ & 6.4 & 9.0 & 9.0 & 17 & 34.1 & $13^{\mathrm{a}}$ & 15 \\
\hline Research octane number & 98 & - & 115 & 110 & - & 120 & 106 & - & - \\
\hline Enthalpy of vaporization $(\mathrm{kJ} / \mathrm{kg})$ & $350^{a}$ & $270^{\mathrm{a}}$ & 1100 & 900 & 375 & 510 & 455 & - & - \\
\hline Flammability limit (\% vol.) & $1.3-8$ & $0.6-8$ & $7-36$ & $4.3-19$ & $3.4-19$ & - & $4-75$ & - & - \\
\hline Flash point $\left({ }^{\circ} \mathrm{C}\right)$ & -40 & $60-80$ & 11 & 12 & -41 & - & - & 62 & 500 \\
\hline Oxygen content (wt.\%) & - & - & 50 & 35 & 34.8 & - & - & 10.7 & - \\
\hline Carbon content (wt.\%) & - & - & - & - & 52.2 & - & - & 76.9 & 86.44 \\
\hline
\end{tabular}

${ }^{a}$ Approximately. Compiled by the authors. 


\subsection{Utilization of Biofuels in Spark Ignition Engines}

Generally, for a particular fuel to be suitable as a renewable alternative fuel for SI engine applications, it must meet the requirements for the octane number, flammability, combustion stability, the heating value of the air-fuel mixture, the laminar burning velocity, vapor pressure, the boiling curve, and volatility [195]. Against this backdrop, alternative fuels for SI engines can be categorized as either liquid biofuels or gaseous biofuels. Liquid biofuels include bioalcohol (methanol, ethanol, butanol) and gaseous biofuels include biogas and hydrogen. These are the preferred renewable alternatives to replace PBG fuel because of their advantages [174], which include: (i) higher octane numbers than PBG fuels; (ii) fewer olefins and aromatic-structured hydrocarbons than PBG fuels; (iii) lower sulfur content; (iv) higher flash points; (v) safer handling; (vi) better cold flow properties. Furthermore, bioethanol has a higher latent heat of vaporization compared to PBG fuels, and alcohol fuels (oxygenated fuels) have (i) high oxygen content; (ii) lower Reid vapor pressure, resulting in lower emission of volatile organic components during filling at gas stations; and (iii) a lower carbon-to-hydrogen ratio than gasoline fuels, resulting in lower carbon-based emissions. However, there are some drawbacks to the use of these renewable alternatives, including [174]: (i) for alcohol fuels, lower calorific values compared to PBG fuels, resulting in lower power output, (ii) cold starting problems as a result of the high latent heat of vaporization values of renewable fuels, (iii) the oxygenated nature of the alcohol-based fuels, which leads to the generation of more NOx, although NOx emission is reduced due to the high latent heat of vaporization values of renewable fuels.

Biogas, a form of gaseous biofuel, is produced by the digestion of waste. Digestion is a biochemical conversion process for the biological decomposition of waste bacteria either in the presence (aerobic) or absence (anaerobic) of oxygen. Anaerobic digestion (AD) is the preferred method of biogas production due to the following advantages [196]: (i) more efficient organic removal, (ii) the higher organic loading rate, (iii) lower nutrient requirements, (iv) reduced energy consumption, (v) better odor control, (vi) the digestate can be used as fertilizer, (vii) reduced costs for bedding materials, (viii) reduced pathogens associated with manure discharges, (ix) better operational flexibility, and (x) it can provide an extra source of revenue from the sales of the slurry. During AD, various species of bacteria and specialized microorganisms take part in the breakdown of the complex organic matter in the various forms of animal waste that serve as feedstock into smaller molecules to generate a methane-rich gas called biogas. The AD process takes place in an airtight reactor called a digester. The process reaction is as shown in Equation (1), while Table 12 shows the four major steps involved in AD.

$$
\mathrm{C}_{6} \mathrm{H}_{12} \mathrm{O}_{6} \rightarrow 3 \mathrm{CO}_{2}+3 \mathrm{CH}_{4}
$$


Table 12. Process reactions, $\mathrm{pH}$, and microorganisms involved in anaerobic digestion. Adapted from [197,198]. Developed by the authors.

\section{Steps and $\mathrm{pH}$}

Process

Reaction Equations

Microorganisms

Breakdown of large organic polymers

(carbohydrates, fats, and proteins) in biomass

Step 1: Hydrolysis $\mathrm{pH}=5.5-6.0$

into smaller molecules (amino acids, fatty

acids, and simple sugars) to produce hydrogen and acetate

Acidogenic microorganisms further break

down the organic matter in the biomass into

smaller molecules to generate an acidic

environment. The fermentative bacteria

Step 2: Acidogenesis $\mathrm{pH}=6.0-7.0$

generate $\mathrm{NH}_{3}, \mathrm{H}_{2}, \mathrm{CO}_{2}, \mathrm{H}_{2} \mathrm{~S}$, shorter volatile

fatty acids, carbonic acids, alcohols, and other byproducts

Acetogens catabolize the products of

Step 3: Acetogenesis $\mathrm{pH}=6.0-7.0$ acidogenesis into acetic acid, $\mathrm{CO}_{2}$, and $\mathrm{H}_{2}$ which are later converted to methane $\left(\mathrm{CH}_{4}\right)$

by methanogens $\left(\mathrm{c}_{6} \mathrm{H}_{10} \mathrm{O}_{5}\right)_{\mathrm{n}}+\mathrm{nH}_{2} \mathrm{O}=\mathrm{n}\left(\mathrm{C}_{6} \mathrm{H}_{12} \mathrm{O}_{6}\right)$

$\mathrm{C}_{6} \mathrm{H}_{12} \mathrm{O}_{6}+2 \mathrm{H}_{2} \mathrm{O} \rightarrow 2 \mathrm{CH}_{3} \mathrm{COOH}+4 \mathrm{H}_{2}+2 \mathrm{CO}_{2}$

$\mathrm{C}_{6} \mathrm{H}_{12} \mathrm{O}_{6}+2 \mathrm{H}_{2} \rightarrow 2 \mathrm{CH}_{3} \mathrm{CH}_{2} \mathrm{COOH}+2 \mathrm{H}_{2} \mathrm{O}$

$\mathrm{C}_{6} \mathrm{H}_{12} \mathrm{O}_{6} \rightarrow 2 \mathrm{CH}_{3} \mathrm{CH}_{2} \mathrm{COOH}+2 \mathrm{H}_{2}+2 \mathrm{CO}_{2}$

$\mathrm{C}_{6} \mathrm{H}_{12} \mathrm{O}_{6} \rightarrow 2 \mathrm{CH}_{3} \mathrm{CH}_{2} \mathrm{OH}+2 \mathrm{CO}_{2}$

$\mathrm{C}_{6} \mathrm{H}_{12} \mathrm{O}_{6} \rightarrow 2 \mathrm{CH}_{3} \mathrm{CHOHCOOH}$

$\mathrm{CH}_{3} \mathrm{CH}_{2} \mathrm{OH}+\mathrm{H}_{2} \mathrm{O} \rightarrow \mathrm{CH}_{3} \mathrm{COOH}+2 \mathrm{H}_{2}$

$2 \mathrm{CH}_{3} \mathrm{CH}_{2} \mathrm{OH}+\mathrm{CO}_{2} \rightarrow \mathrm{CH}_{4}+2 \mathrm{CH}_{3} \mathrm{COOH}$

$\mathrm{CH}_{3} \mathrm{CH}_{2} \mathrm{COOH}+2 \mathrm{H}_{2} \mathrm{O} \rightarrow \mathrm{CH}_{3} \mathrm{COOH}+3 \mathrm{H}_{2}+\mathrm{CO}_{2}$

$\mathrm{CH}_{3} \mathrm{CH}_{2} \mathrm{CH}_{2} \mathrm{COOH}+2 \mathrm{H}_{2} \mathrm{O} \rightarrow 2 \mathrm{CH}_{3} \mathrm{COOH}+2 \mathrm{H}_{2}$

$\mathrm{CH}_{3} \mathrm{CHOHCOOH}+\mathrm{H}_{2} \mathrm{O} \rightarrow \mathrm{CH}_{3} \mathrm{COOH}+\mathrm{CO}_{2}+2 \mathrm{H}_{2}$
Lactobacillus, Escherichia, Bacillus, Veollonella

Desulfobacter, Deslforomonas,

Clostridium, Eubacterium

Clostridium, Syntrophomonas
Clostridium, Proteus, Vibrio, Bacillus,

Peptococcus, Bacteroides, Staphylococcus

Methanogens generate $\mathrm{CH}_{4}$ and other

Step 4: Methanogenesis $\mathrm{pH}=6.5-7.5$ acetogenesis via two routes

$\mathrm{CH}_{3} \mathrm{COOH} \rightarrow \mathrm{CH}_{4}+\mathrm{CO}_{2}$

$\mathrm{CO}_{2}+4 \mathrm{H}_{2} \rightarrow \mathrm{CH}_{4}+2 \mathrm{H}_{2} \mathrm{O}$

Methanobrevibacter

Methanoplanus,

Methanospirillum

Stophlococcus, Pseudomonas, Sarcina,

Desulfovibro, Selenomonas, Streptococcus,

Methanobacterium, 
Biogas is used to power SI engines either as raw biogas or enriched biogas. Raw biogas is approximately $60 \% \mathrm{CH}_{4}$ and roughly $40 \% \mathrm{CO}_{2}$ with $\mathrm{H}_{2} \mathrm{~S}, \mathrm{~N}_{2}$, and $\mathrm{H}_{2}$ in trace proportions [199]. Raw biogas suffers from lower flame velocities and calorific values when compared with gasoline fuel. SI engines fueled with raw biogas thus have poor combustion characteristics, lower thermal efficiency, higher specific fuel consumption, lower power output, and higher emissions of $\mathrm{CO}$ and $\mathrm{HC}$ because of the lower flame velocity, less adiabatic flame temperature, and lower calorific value of biogas compared to PBG fuels. To enhance the quality of the unrefined biogas, the $\mathrm{CH}_{4}$ content of the biogas can be enriched and the $\mathrm{CO}_{2}, \mathrm{H}_{2} \mathrm{~S}$, and water content reduced or removed. The upgraded biogas is called biomethane and possesses acceptable specifications for ICEs [200]. Various technologies and techniques have been successfully employed, at household and commercial scales, to upgrade and enrich biogas, including physical and chemical absorption, gas filtration, low-temperature separation, and various methods of scrubbing [198-203].

The $\mathrm{CH}_{4}$ content of enriched biogas can be as high as 95\% [198]. Though enrichment of biogas imposes an additional cost on the fuel, biomethane is ultimately more valuable when factors relating to storage, pipeline gas transportation, and the superior performance and the reduced emissions characteristics of SI engines compared to raw biogas are taken into account. The application of biomethane as an SI engine fuel ensures clean combustion, which gives rise to low particulates and NOx and decreased infiltration of engine oil. To use biogas to power an SI engine, the carburetor must be replaced with a device for mixing air/biogas [204]. Generally, biogas is employed to power both light- and heavy-duty vehicles. A gasoline car can be converted to run on biogas as a secondary fuel by attaching a separate fuel supply structure and airtight storage cylinders for the biogas [205]. The use of biomethane is becoming remarkably widespread in Germany, Sweden, and the United Kingdom, where biogas generated from municipal waste and wastewater remediation plants is being employed as alternative fuel for buses and other on-road SI engines [206]. Biomethane utilization in the transport sector is projected to rise from about 1 billion $\mathrm{m}^{3}$ in 2016 to 13 billion $\mathrm{m}^{3}$ in 2050 [179].

Hydrogen, which has been used in the hydrocracking of petroleum products, ammonia production, the heat-treating and refining of metals, the catalytic hydrogenation of organic compounds, fertilizer production, glass purification, and other applications, has also found uses as an alternative fuel for SI engines as part of emission mitigation strategies. An estimated 120 million tons of hydrogen, equivalent to $14.4 \mathrm{EJ}$, are produced annually, with about $95 \%$ produced from fossil fuels (natural gas and coal) and the remaining $5 \%$ generated by the electrolysis process [207]. Various technologies have been deployed for the production of hydrogen to meet its growing demand. Photochemical, thermochemical, and electrochemical methods are the three main technologies that have been employed for the production of hydrogen from various sources [208]. Fuel hydrogen is also generated using biological routes, including direct and indirect bio-photolysis and dark fermentation and photofermentation with organisms like cyanobacteria and green algae [209]. Sharma and Ghoshal [210] surveyed various technologies for hydrogen fuel production, including steam methane reforming, gasification of coal, electrolysis of water, and technologies using biomass and nuclear energy. The application of hydrogen as a substitute fuel for SI engines has been reported by various researchers [211,212].

The utilization of hydrogen fuel to power SI engines has gained wide acceptance thanks to its benefits. The distinctive fingerprints of hydrogen, such as its low ignition energy, high diffusion coefficient, flammability, high flame velocity, and high octane number, make it a favorable candidate for SI engines [213]. The use of hydrogen ensures clean combustion, higher thermal efficiency, and zero emission of $\mathrm{CO}, \mathrm{CO}_{2}, \mathrm{HC}, \mathrm{PM}$, and other carbon-based substances. SI engines fueled with hydrogen entail technical challenges, such as backfires, power drops, and high NOx emissions [174,214]. To evade these drawbacks, hydrogen can be blended with a quantity of $\mathrm{CH}_{4}$ to ensure good knocking resistance, a richer air/fuel mixture, and better power performance [214]. 
Bioethanol is one of the most prominent biofuels because of its easy production method and the use of native and readily available raw materials as feedstocks. Currently, bioethanol accounts for about $65 \%$ of total biofuel production, with global production projected to increase from 100.2 billion liters in 2014 to about 134.5 billion liters by 2024 and the USA and Brazil leading the producing countries [215]. Bioethanol is produced through the fermentation of various raw materials including sugarcane molasses, sugar beet, sweet sorghum, rice, potato, sweet potato, barley, and fruit and vegetable waste. Fermentation is a biochemical process for the anaerobic conversion of the simple sugars obtained from hydrolysis of lignocellulosic biomass into bioethanol. The process of conversion of lignocellulosic biomass into simple sugars is a complicated procedure due to the existence of long-chain polysaccharide molecules, and it therefore demands acids or enzymes. The anaerobic catabolism of simple sugar by microorganisms yields alcohol, gas, or organic acid, as shown in Equation (2) [216].

$$
\mathrm{C}_{6} \mathrm{H}_{12} \mathrm{O}_{6} \rightarrow 2 \mathrm{C}_{2} \mathrm{H}_{5} \mathrm{OH}+2 \mathrm{CO}_{2}
$$

There are three types of microorganisms frequently utilized for the conversion of lignocellulosic biomass to bioethanol: yeasts, bacteria, and fungi. Yeasts have proven to be the best microorganism for fermentation of biomass to bioethanol. In particular, the yeast Saccharomyces cerevisiae, operating at a temperature of $30^{\circ} \mathrm{C}, \mathrm{pH} 5.5$, and with a fermentation time between $48 \mathrm{~h}$ and $65 \mathrm{~h}$, resulting in an ethanol yield of $130.13 \mathrm{~g} / \mathrm{L}$ [217], and the bacterium Zymomonas mobilis, operating at a temperature of $30^{\circ} \mathrm{C}, \mathrm{pH} 6.0$, and with a fermentation time of $18 \mathrm{~h}$, resulting in an ethanol yield of $99.78 \mathrm{~g} / \mathrm{L}$ [218], have been used for commercial production of ethanol.

The homolactic and heterotactic fermentation processes, shown in Equations (3) and (4), respectively, are employed for the production of organic acids.

$$
\begin{gathered}
\mathrm{C}_{6} \mathrm{H}_{12} \mathrm{O}_{6} \rightarrow 2 \mathrm{CH}_{3} \mathrm{CHOHCOOH} \\
\mathrm{C}_{6} \mathrm{H}_{12} \mathrm{O}_{6} \rightarrow \mathrm{CH}_{3} \mathrm{CHOHCOOH}+\mathrm{C}_{2} \mathrm{H}_{5} \mathrm{OH}+\mathrm{CO}_{2}
\end{gathered}
$$

The produced ethanol is distilled and desiccated to high-octane, waterless alcohol. In addition to feedstocks such as sugar crops and starch crops, lignocellulosic biomass, like wood and cereals, can be converted to ethanol $[219,220]$. Table 13 shows the effects of some

\begin{tabular}{|c|c|c|c|c|}
\hline \multirow{2}{*}{ Biofuel Used } & \multirow{2}{*}{ Engine Details } & \multicolumn{2}{|c|}{ Effect } & \multirow{2}{*}{ Ref. } \\
\hline & & Performance & Emission & \\
\hline Hydrogen & $1 \mathrm{C}, 4 \mathrm{~S}, \mathrm{NA}$, air-cooled, $\mathrm{r}=8.5$ & $\begin{array}{ll}- & \downarrow 16.1 \% \mathrm{BP}, 16.1 \% \\
& \mathrm{BMEP}, 3.53 \% \\
& \mathrm{BSFC} \\
\text { - } & \uparrow 3.7 \% \text { BTE }\end{array}$ & $\begin{array}{ll}- & \uparrow 83.6 \% \text { NOx } \\
- & \downarrow \mathrm{CO}, \mathrm{UHC}\end{array}$ & [213] \\
\hline Hydrogen & $1 C, 4 S, N=3600$ rpm generator set & $\begin{array}{l}\text { - } \quad \begin{array}{l}\text { BTE and power } \\
\text { output }\end{array}\end{array}$ & - $\quad \uparrow N O x$ & [221] \\
\hline Hydrogen & $4 \mathrm{C}$, water-cooled, $r=10$ & - $\quad \uparrow \mathrm{BSFC}, \mathrm{BTE}$ & - $\quad \uparrow \mathrm{HC}, \mathrm{CO}, \mathrm{NOx}$ & [222] \\
\hline Hydrogen & $6 \mathrm{C}, 4 \mathrm{~S}$ in line, turbocharged, intercooler & $\begin{array}{ll}- & \uparrow \mathrm{BTE} \\
\cdot & \downarrow \mathrm{BSFC}\end{array}$ & $\begin{array}{ll}\text { - } & \downarrow \mathrm{UHC}, \mathrm{CO}, \mathrm{CO}_{2} \\
\text { - } & \uparrow \mathrm{NOx}\end{array}$ & [223] \\
\hline Methanol & $1 \mathrm{C}, 4 \mathrm{~S}$, air-cooled, $\mathrm{N}=1500 \mathrm{rpm}, \mathrm{r}=10.5$ & $\begin{array}{ll}\text { - } & \downarrow \text { BTE, BP } \\
\text { - } & \uparrow \mathrm{BSFC}\end{array}$ & $\begin{array}{ll}\text { - } & \downarrow \mathrm{NOx}, \mathrm{UHC}, \mathrm{CO} \\
\text { - } & \uparrow \mathrm{CO}_{2}\end{array}$ & [224] \\
\hline
\end{tabular}
alternative fuels on the performance and emission behaviors of SI engines.

Table 13. Effects of alcohol, biogas, and hydrogen as alternative fuels for SI engines. 
Table 13. Cont.

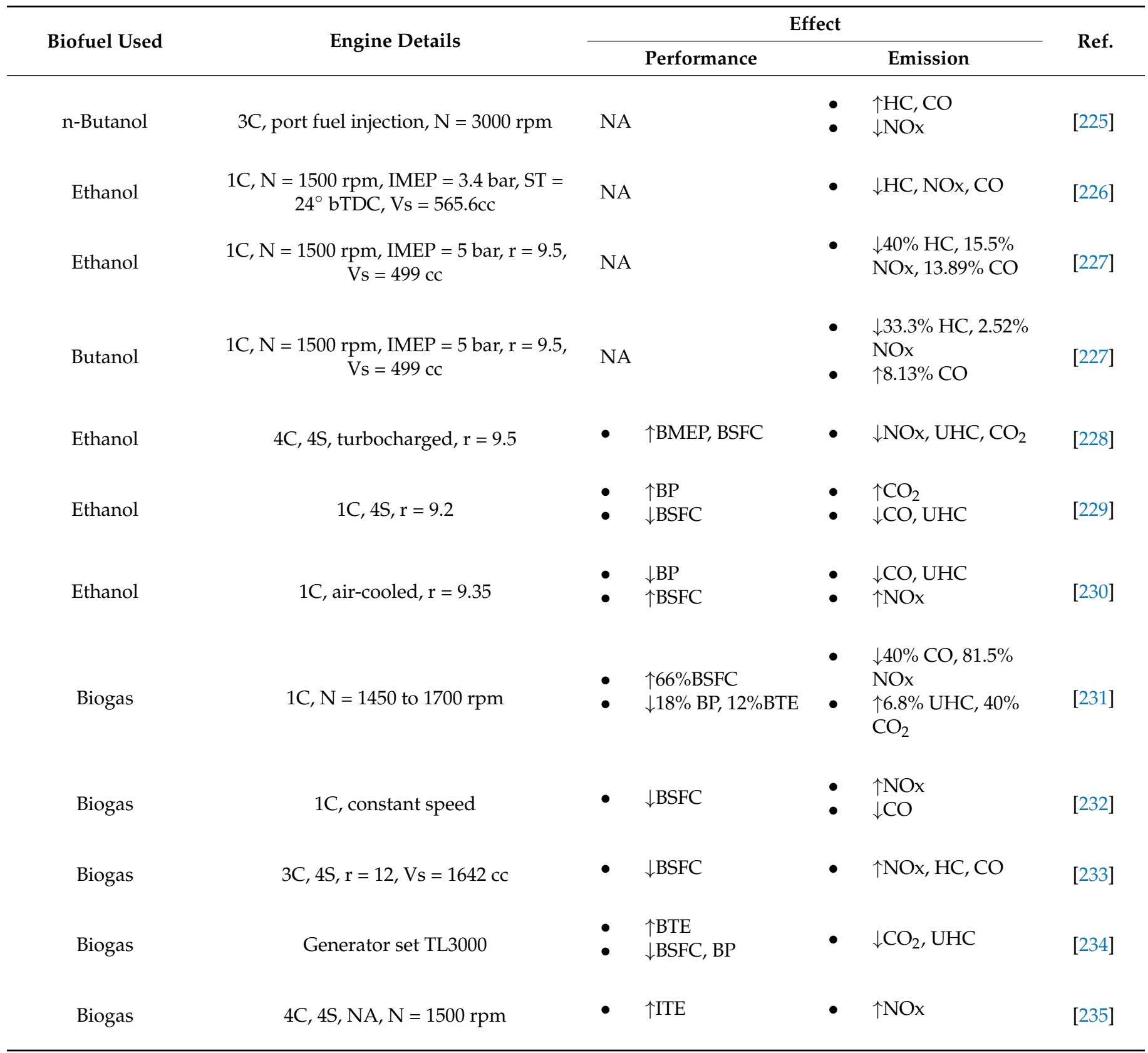

$\mathrm{C}=$ cylinder, $\mathrm{N}$ = engine speed, $\mathrm{NA}=$ naturally aspirated, $\mathrm{S}=$ stroke, IMEP $=$ indicated mean effective pressure, Vs = swept volume, $\mathrm{r}=$ crank radius, $\mathrm{bTDC}=$ before top dead center, ITE $=$ indicated thermal efficiency, BP $=$ brake power, BTE = brake thermal efficiency, BSFC $=$ brake-specific fuel consumption, $\uparrow=$ increased, $\downarrow=$ reduced.

\subsection{Utilization of Biofuels in Compression Ignition Engines}

Compression ignition (CI) engines have better thermal efficiency than SI engines and have found applications in diverse areas, including transportation, construction, agriculture, and power generation. The need for renewable fuel to power CI engines results from the poor performance and hazardous emissions, particularly of $\mathrm{CO}, \mathrm{UHC}, \mathrm{NOx}$ (NO and $\mathrm{NO}_{2}$ ), and PM, of $\mathrm{CI}$ engines fueled with PBD fuel. The selection of fuels for $\mathrm{CI}$ engines is based, primarily, on the cetane number of the fuel. A fuel candidate for CI engines must meet some important criteria, namely [195]: a good cetane number, appropriate boiling point, a narrow density and viscosity spread, and low aromatic compound content. Such fuel must ensure quality ignition, combustion without knock, and smooth running of the engine. Biodiesel, Fischer-Tropsch (F-T) fuel, and dimethyl ether (DME) are the 
preferred renewable fuels for CI engines because of their [174] higher cetane numbers and lower levels of olefins and aromatic-structured hydrocarbons compared to PBD fuels. Furthermore, biodiesel and F-T fuels have higher flash points than PBD fuels, but F-T and DME fuels have better cold flow properties than biodiesel.

Biodiesel and its blends have been used to power $\mathrm{CI}$ engines due to their characteristic oxygenated fingerprints, which support complete combustion. Though the combustion, performance, and emissions characteristics of biodiesel as a CI engine fuel have been studied, the determining factors that have engaged the interest of researchers are the improved performance and mitigated emissions characteristics of unretrofitted engines fueled with biodiesel. Over the years, biodiesel has been produced from various feedstocks, and the products have been tested and compared with PBD fuel using the BSFC, BTE, BP, and EGT as performance criteria and measurement of NOx, PM, UHC, and CO emission benchmarks. The ultimate goal is to make biodiesel-fueled CI engines consume less fuel, generate more power, and emit less hazardous gases [174,236]. Biodiesel, due to its increased oxygen content, has low calorific values and consequently emits more NOx emissions and suffers from power drops.

F-T diesel is produced through a catalytic chemical reaction where syngas derived from biomass are converted into hydrocarbons of various molecular weights. The $\mathrm{H}_{2}$ and $\mathrm{CO}$ in the syngas are involved in the reaction according to Equation (5). The reaction takes place at a temperature range of $200-350{ }^{\circ} \mathrm{C}$ and pressure range of $390-660 \mathrm{psi}$. The FischerTropsch process is a catalytic exothermic reaction that can take place in a fixed bed, fluidized bed, or slurry bed reactor in the presence of iron, cobalt, or nickel catalysts [209,210].

$$
(2 \mathrm{n}+1) \mathrm{H}_{2}+\mathrm{nCO} \rightarrow \mathrm{C}_{\mathrm{n}} \mathrm{H}_{2 n+2}+\mathrm{nH}_{2} \mathrm{O} \mathrm{n}=10-20
$$

F-T diesel has a higher calorific value, higher cetane number, and lower density than PBD fuel. F-T diesel fuel contains more paraffinic compounds, has a lower $\mathrm{C} / \mathrm{H}$ ratio, lower in-cylinder temperature, lower aromatic or sulfur content, and better combustion properties, resulting in lower NOx, $\mathrm{UH}, \mathrm{CO}$, and $\mathrm{PM}$ emissions in comparison with $\mathrm{PBD}$ fuel. F-T diesel has better cold flow properties and superior transportation and storage properties when compared with biodiesel. F-T diesel-fueled CI engines emit less NOx emissions and suffer from fewer power drops, making F-T diesel a better renewable fuel than biodiesel for CI engine applications [237].

Dimethyl ether (DME) a clean, colorless, non-toxic, and degradable gas, which was originally applied as an aerosol propellant and in LPG blending for cooking, has become a prominent alternative to FB fuels. Currently, there is large-scale production of DME in many countries, including the USA, Canada, Uzbekistan, Russia, Mexico, Brazil, Argentina, China, Japan, Sweden, India, and South Korea. According to the International DME Association, current global production is about 9 million tons per annum while the global market size, which was USD 5.6 billion in 2020, has been projected to reach USD 9.7 billion in $2027[238,239]$.

DME can be produced from biomass, coal, municipal waste, natural gas, methanol, agricultural bio-products, and other bio-based feedstocks through either direct or indirect routes. In the indirect production route, methanol is hydrogenated from syngas and the product is purified and dehydrated. Direct synthesis of DME is achieved in a single-stage process directly from syngas in an exothermic reaction [207]. Inayat et al. [208] investigated the use of an empty fruit bunch as feedstock to synthesize DME in a production process that involved gasification, waster-gas shift reactions, and $\mathrm{CO}_{2}$ removal. Partial oxidation, gasification, Boudouard, methanation, and methane-reforming reactions take place during the gasification stage. The schematic diagram of the production process is shown in Figure 10, while Equations (6)-(13) are the reaction equations [208].

$$
\begin{gathered}
\text { Gasification; partial oxidation : } \mathrm{C}_{3.4} \mathrm{H}_{4.1} \mathrm{O}_{3.3}+2.775 \mathrm{O}_{2} \rightarrow 3.4 \mathrm{CO}_{2}+2.05 \mathrm{H}_{2} \mathrm{O} \\
\text { Gasification : } \mathrm{C}_{3.4} \mathrm{H}_{4.1} \mathrm{O}_{3.3}+0.1 \mathrm{H}_{2} \mathrm{O} \leftrightarrow 2.15 \mathrm{H}_{2}+3.4 \mathrm{CO}_{2}
\end{gathered}
$$




$$
\begin{gathered}
\text { Boudouard reaction : } \mathrm{C}_{3.4} \mathrm{H}_{4.1} \mathrm{O}_{3.3}+\mathrm{CO}_{2} \leftrightarrow 4.4 \mathrm{CO}_{2}+0.9 \mathrm{H}_{2} \mathrm{O}+1.15 \mathrm{H}_{2} \\
\text { Methanation : } \mathrm{C}_{3.4} \mathrm{H}_{4.1} \mathrm{O}_{3.3}+8.05 \mathrm{H}_{2} \leftrightarrow 3.4 \mathrm{CH}_{4}+3.3 \mathrm{H}_{2} \mathrm{O} \\
\text { Methane }- \text { reforming : } \mathrm{CH}_{4}+\mathrm{H}_{2} \mathrm{O} \leftrightarrow \mathrm{CO}+3 \mathrm{H}_{2} \\
\text { Water }- \text { gas shift : } \mathrm{CO}+\mathrm{H}_{2} \mathrm{O} \leftrightarrow \mathrm{H}_{2}+\mathrm{CO}_{2} \\
\mathrm{CO} 2 \text { removal : } \mathrm{CaO}+\mathrm{CO}_{2} \leftrightarrow \mathrm{CaCO}_{3}
\end{gathered}
$$

DME synthesis : $3 \mathrm{CO}+3 \mathrm{H}_{2} \leftrightarrow \mathrm{CH}_{3} \mathrm{OCH}_{3}+\mathrm{CO}_{2}$

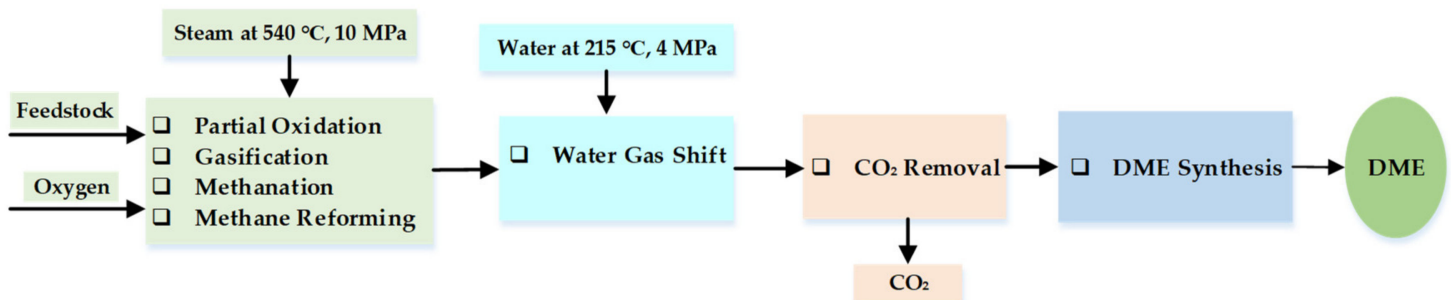

Figure 10. Schematic diagram of the DME production process. Adapted from [194]. Developed by the authors.

As a result of its many applications, the global DME market, appraised at USD 4790 million in 2017, is projected to reach USD 9100 million in 2024 [238]. DME as a CI engine fuel discharges low NOx, SOx, and soot emissions and has outstanding combustion attributes [239]. The choice of $\mathrm{DME}\left(\mathrm{CH}_{3} \mathrm{OCH}_{3}\right)$ as a sustainable fuel for $\mathrm{CI}$ engines is strengthened by its superior oxygen content, which allows better combustion and lower NOx, UHC, and smoke emissions, higher cetane numbers, and shorter ignition delays than PBD fuel. The emission of less smoke and PM can also be attributed to the lack of $\mathrm{C}-\mathrm{C}$ bonds, as DME has only $\mathrm{C}-\mathrm{H}$ and $\mathrm{C}-\mathrm{O}$ bonds. DME-fueled $\mathrm{CI}$ engines offer the best emissions when compared with biodiesel and F-T diesel, but its utilization as a vehicle fuel and its adoption for vehicle fleets is hampered by the lack of production, storage, transport, and dispensing infrastructures. Also, DME has lower lubricity, resulting in increased wear of moving parts; lower viscosity, which can cause leakages in fuel pumps and fuel

\begin{tabular}{|c|c|c|c|c|}
\hline \multirow{2}{*}{ Biofuel Used } & \multirow{2}{*}{ Engine Details } & \multicolumn{2}{|c|}{ Effects } & \multirow{2}{*}{ Ref. } \\
\hline & & Performance & Emissions & \\
\hline Biodiesel & 1C, 4S, NA, DI, air-cooled & $\begin{array}{ll}- & \uparrow \mathrm{BSFC} \\
\text { - } & \downarrow \mathrm{BTE}\end{array}$ & $\begin{array}{l}\text { - } \quad \uparrow \mathrm{CO}, \mathrm{CO}_{2}, \mathrm{NOx}, \\
\text { - } \quad \downarrow \mathrm{HC}, \mathrm{SO}\end{array}$ & [241] \\
\hline Biodiesel & $1 \mathrm{C}$, common-rail DI, $r=16$ & $\begin{array}{ll}\bullet & \uparrow \mathrm{BTE} \\
\text { - } & \downarrow \mathrm{BSFC}\end{array}$ & $\begin{array}{ll}\text { - } & \uparrow \mathrm{SO}, \mathrm{CO}, \mathrm{UHC} \\
\text { - } & \downarrow \mathrm{NOx}\end{array}$ & [242] \\
\hline Biodiesel & $\begin{array}{l}\text { 1C, } 4 \text { S, DI, VCR, } \\
\text { water-cooled }\end{array}$ & $\begin{array}{ll}\text { - } & \uparrow \mathrm{BTE}, \mathrm{BSFC}, \mathrm{EGT} \\
\text { - } & \downarrow \mathrm{BP}\end{array}$ & $\begin{array}{ll}- & \uparrow \mathrm{NOx} \\
\text { - } & \downarrow \mathrm{UHC}, \mathrm{CO}, \mathrm{SO}\end{array}$ & [243] \\
\hline Biodiesel & $\begin{array}{c}\text { 2C, water-cooled, } \mathrm{r}=17.5 \\
\mathrm{~N}=1500 \mathrm{rpm}\end{array}$ & $\begin{array}{l}\text { - } \quad \uparrow \mathrm{BTE}, \mathrm{BSFC}, \mathrm{EGT} \\
\text { - } \quad \downarrow \mathrm{BP}\end{array}$ & $\begin{array}{l}\text { - } \quad \uparrow \mathrm{CO} 2, \mathrm{NOx}, \mathrm{SO} \\
\text { - } \quad \downarrow \mathrm{CO}, \mathrm{UHC}\end{array}$ & [244] \\
\hline Biodiesel & $\begin{array}{l}\text { 1C, } 4 \mathrm{~S}, \text { constant speed, } \\
\text { water-cooled }\end{array}$ & $\begin{array}{ll}- & \uparrow 4.2 \% \text { BSFC } \\
\bullet & \downarrow 10.8 \% \text { BP, } 3.6 \% \\
& \text { BTE }\end{array}$ & $\begin{array}{ll}\text { - } & \uparrow \mathrm{CO} 2, \mathrm{NOx}, \\
- & \downarrow \mathrm{CO}, \mathrm{UHC}, \mathrm{SO}\end{array}$ & [245] \\
\hline
\end{tabular}
injectors; and higher flammability limits than PBD fuel $[174,237,240]$. Table 14 shows data on biodiesel-, F-T diesel-, and DME-fueled CI engines in terms of their performance and emission characteristics.

Table 14. Effects of biodiesel, F-T diesel, and DME as alternative fuels for CI engines. 
Table 14. Cont.

\begin{tabular}{|c|c|c|c|c|}
\hline \multirow{2}{*}{ Biofuel Used } & \multirow{2}{*}{ Engine Details } & \multicolumn{2}{|c|}{ Effects } & \multirow{2}{*}{ Ref. } \\
\hline & & Performance & Emissions & \\
\hline DME & $1 \mathrm{~S}$, common-rail injection & - $\quad \uparrow \mathrm{IMEP}$ & $\begin{array}{ll}\text { - } & \uparrow \mathrm{NOx}, \\
\text { - } & \downarrow \text { HC, } \mathrm{CO} \\
& \text { Almost zero soot }\end{array}$ & {$[246]$} \\
\hline DME & $\begin{array}{c}1 \mathrm{~S}, 4 \mathrm{~S}, \mathrm{DI} \text {, water-cooled, } \mathrm{r}= \\
18, \mathrm{~N}=2200 \mathrm{rpm}\end{array}$ & NA & - $\quad \downarrow \mathrm{CO}, \mathrm{HC}, \mathrm{NOx}$ & {$[247]$} \\
\hline DME & $\begin{array}{l}4 \mathrm{C}, \mathrm{NA} \text {, in-line, common } \\
\text { rail, } \mathrm{r}=18.5\end{array}$ & $\begin{array}{ll}- & \uparrow \mathrm{BSFC} \\
- & \downarrow \mathrm{BTE}, \mathrm{EGT}\end{array}$ & - $\quad \uparrow \mathrm{NOx}, \mathrm{HC}, \mathrm{CO}$ & {$[248]$} \\
\hline DME & $1 \mathrm{~S}$, common rail, $\mathrm{r}=16.7$ & $\begin{array}{ll}\text { - } & \uparrow \mathrm{BSFC}, \mathrm{BTE} \\
& \downarrow \mathrm{EGT}\end{array}$ & $\begin{array}{ll}\text { - } & \uparrow \mathrm{NOx} \\
\quad \downarrow \mathrm{CO}, \mathrm{HC}, \mathrm{PM}\end{array}$ & {$[249]$} \\
\hline F-T & $\begin{array}{c}1 \mathrm{~S}, 4 \mathrm{~S}, \mathrm{NA}, \mathrm{DI} \\
\text { water-cooled, } \mathrm{r}=18\end{array}$ & - $\quad \downarrow \mathrm{BSFC}$ & $\begin{array}{l}\text { - } \quad \downarrow \mathrm{CO}, \mathrm{CO}_{2}, \mathrm{HC}, \\
\mathrm{NOx}, \mathrm{SO}\end{array}$ & {$[250]$} \\
\hline
\end{tabular}

$\uparrow=$ increased, $\downarrow$ = reduced, DI = direct injection, EGT = exhaust gas temperature, VCR = variable compression ratio, $\mathrm{SO}=$ smoke opacity, $\mathrm{C}=$ cylinder, $\mathrm{N}=$ engine speed, $\mathrm{NA}=$ naturally aspirated $\mathrm{S}=$ stroke, IMEP = indicated mean effective pressure, Vs = swept volume, $\mathrm{r}=$ crank radius, $\mathrm{BP}=$ brake power, $\mathrm{BTE}=$ brake thermal efficiency, $\mathrm{BSFC}=$ brake specific fuel consumption.

\section{Prospects for Biofuel Conversion Techniques}

The application of biofuel as an alternative to FB fuels faces many challenges associated with its conversion technologies. There are concerns about the use of water in the conversion process, conversion costs, energy requirements, the availability and maturity of conversion technologies, and the carbon neutrality of the conversion technologies, which all need to be considered and addressed [251]. For this to occur, there is a need for technical, economic, and life-cycle assessments of the various conversion technologies. The drawbacks associated with the production of $1 \mathrm{~GB}$ and $2 \mathrm{~GB}$ biofuels are partly being overcome by the conversion technologies of 3GB and 4GB biofuels, such as the use of the microalgae conversion processes [109].

Microalgae feedstock no doubt offers some advantages when compared to conventional crop plants. Microalgae, which are sophisticated microorganisms, can be cultivated with less effort, have multiple cultivation cycles, offer better photosynthetic performance, have short harvesting cycles (less than 10 days), and offer significant continuous and enhanced yields. The various methods of algae cultivation like open ponds and close photobioreactors, and the algae conversion technologies, like oil transesterification, ethanol fermentation, anaerobic digestion, etc., are still at the laboratory or pilot stages. Commercial and large-scale implementation is plagued with uncertainties that are yet to be addressed. Apart from the technical issues, like photobioreactor design, other economic and operational challenges need to be dealt with. Large-scale algae cultivation through photobioreactors, though practicable and effective, is still expensive and not commercially viable. The less expensive and less technically demanding open-pond algae cultivation is susceptible to evaporation and contamination by native algae species. For these reasons, algae harvesting and processing are not yet being undertaken at a scale that would make the large-scale generation of liquid biofuel from microalgae technically feasible and economically realistic [252,253].

The transformation of biomass into hydrocarbon fuels through aqueous phase reforming (APR) has been proposed [254,255]. Through APR, compounds like glycerol, sugars, and sugar alcohols can be obtained from biomass and converted into hydrogen and light alkanes. In these cases, the raw materials are in the liquid phase while the products are generated at lower temperatures compared to with gasification or pyrolysis, thereby averting costly and highly energy demanding vaporization processes. The conversion 
of sugars into paraffin molecules through fermentation by direct sugar-to-hydrocarbon technologies could offer a pathway to biofuel production on a commercial scale when fully developed and harnessed [256,257].

The use of combined technologies for biofuel production through renewable solar fuel generation, called helioculture, offers hope for better biofuel conversion technology in the future. This highly innovative conversion pathway produces ethanol or hydrocarbons directly and any upgrade of the technology will not be difficult to apply in practice. For example, the authors of [106] generated over 20,000 gallons of fuel per acre per annum (or $19,000 \mathrm{~m}^{3}$ per square kilometer).

\section{Implications}

Biofuels have been widely accepted as alternative fuels for the transportation sector to enhance the performance of transport vehicles. The challenges associated with the application of FB fuels as ICE fuels include operational, performance, safety, cost, infrastructural, and availability challenges. The conversion of various categories of waste into useful fuels has become advantageous in terms of economic, sanitation, availability, and environmental considerations. The choice of feedstock, conversion technology, production infrastructure, and utilization platform cannot be restricted to fuel producers and engine manufacturers but must involve professionals from many disciplines, including finance, plant science, microbiology, chemical engineering, mechanical engineering, process engineering, environmental science, food science, agronomy, and more. Investigations into areas such as metabolic engineering, processing subsidizations, tax immunity, feedstock identification, equipment development, engine modifications, land use regulations, and the use of artificial intelligence, are needed to ensure the sustainable production and application of biofuels [258-260]. Political leaders from various jurisdictions, policymakers, funders, investment analysts, and other development partners must unite in making biofuel production and utilization worthwhile and sustainable.

The current review contributes to the body of knowledge by providing up-to-date information on the classification, production, and utilization of biofuels with a view to enhancing and enriching the available data. A new vista in the classification of biofuels is here unveiled to ensure more comprehensive knowledge and information sharing along the biofuel value chain. Deployments of biodiesel, biogas, F-T diesel, DME, and bioethanol to replace FB fuels in SI and CI engines have been highlighted from the perspectives of performance and emissions advantages. The outcomes of this investigation enable renewable fuel refiners, engine designers, emission specialists, environmentalists, and consumers to be better informed about the strategies available to boost the performance and emissions characteristics of ICEs through the application of biofuels.

\section{Conclusions and Outlook}

The application of renewable fuels offers benefits and advantages. Their utilization can improve the environmental condition and air quality since only a low amount or no GHGs are generated. Biofuels can also solve energy security and poverty issues by making energy available equally without undue discrimination and political victimization. They can make affordable energy available, stabilize energy prices, provide employment, and improve living conditions. Studies have shown that reductions in GHG emissions have led to reduced cases of health problems and contribute to healthy living and wellbeing. The production of some forms of biofuel, like biogas and biodiesel, contributes to proper waste disposal and conversion of waste to energy for household use, thereby reducing the cost of energy for heating and cooking in rural households. However, there are some limitations to the adaptation and utilization of biofuels and bioenergy as sustainable alternatives to FB fuels. The high initial cost, highly technical conversion technologies, and highly skilled personnel required limit the application of some categories of biofuel and bioenergy. Some of the technologies for the utilization of some categories of biofuels cannot be deployed domestically, thereby limiting their accessibility and utilization. The adap- 
tation of existing FB fuel distribution and transportation infrastructures needs time and financial resources and is unaffordable for individuals and households.

With the increased popularity of EVs, more innovative research along with technologies that allow the efficient use of biofuels as flexible hybrid fuels are needed to fully enjoy the benefits of biofuel as a transport vehicle fuel. The requirement to mitigate GHGs and other emissions presents an incentive and a giant motivation for the utilization of biofuels, but an appropriate infrastructure and policy framework needs to be in place to ensure gradual uptake. Given the right environment and context, and the political will of governments at various levels, biofuels can be strong drivers for a cleaner environment through waste minimization, proper waste disposal, effective waste conversion, and mitigation of climate change. However, adequate controls are required, as the extent to which biofuel can be deployed sustainably is constrained by the available land, infrastructure, technical know-how, and sustainable practices. Effective policies, education, awareness campaigns, and programs, along with more research and development initiatives, are needed to ensure that the lifecycle emissions from biofuel offer substantial savings compared to FB fuels. There is a need for sufficiently sustainable frameworks and techniques to ensure GHG emissions are not created in the processes of conversion and deployment in the biofuel value chain.

Author Contributions: Conceptualization; O.A., D.V.V.K., E.I.O., V.S.A.; Methodology; O.A., D.V.V.K., E.I.O., V.S.A.; Software; O.A., D.V.V.K., E.I.O., V.S.A.; Investigation; O.A., D.V.V.K., E.I.O., V.S.A.; Writing-Original draft preparation; O.A.; Writing-Review and Editing; D.V.V.K., E.I.O., V.S.A.; Supervision; D.V.V.K., E.I.O.; Funding acquisition; D.V.V.K. All authors have read and agreed to the published version of the manuscript.

Funding: This reseach was funded by the the Postgraduate school and the Faculty of Engineering and Built Environment, University of Johannesburg, Auckland Park Kingsway, South Africa. The APC was funded by the Library, University of Johannesburg, Auckland Park Kingsway, South Africa.

Conflicts of Interest: The authors declare no conflict of interest.

\section{References}

1. Nguyen, K.H.; Kakinaka, M. Renewable energy consumption, carbon emissions, and development stages: Some evidence from panel cointegration analysis. Renew. Energy 2019, 132, 1049-1057. [CrossRef]

2. BP. Statistical Review of World Energy. 2016. Available online: https://www.bp.com/en/global/corporate/energy-economics/ statistical-review-of-world-energy / downloads.html (accessed on 2 June 2020).

3. Ritchie, H.; Roser, M. Fossil Fuels. Our World in Data. 2017. Available online: https://ourworldindata.org/fossil-fuels (accessed on 2 June 2020).

4. World Oil Final Consumption by Sector. 2018. Available online: https://www.iea.org/data-and-statistics/charts/world-oil-finalconsumption-by-sector-2018 (accessed on 25 June 2021).

5. Fossil Fuel Consumption. Available online: https:// ourworldindata.org/fossil-fuels (accessed on 25 June 2021).

6. Statista. Global Biofuel Production from 2000 to 2018. Available online: https://www.statista.com/statistics/274163/globalbiofuel-production-in-oil-equivalent/ (accessed on 5 June 2020).

7. Statista. Leading Countries Based on Biofuel Production in 2018. Available online: https://www.statista.com/statistics/274168 /biofuel-production-in-leading-countries-in-oil-equivalent/ (accessed on 5 June 2020).

8. Lee, S.Y.; Sankaran, R.; Chew, K.W.; Tan, C.H.; Krishnamoorthy, R.; Chu, D.; Show, P.-L. Waste to bioenergy: A review on the recent conversion technologies. BMC Energy 2019, 1, 4. [CrossRef]

9. Guo, M.; Song, W.; Buhain, J. Bioenergy and biofuels: History, status, and perspective. Renew. Sustain. Energy Rev. 2015, 42, 712-725. [CrossRef]

10. Tsita, K.G.; Kiartzis, S.J.; Ntavos, N.K.; Pilavachi, P.A. Next generation biofuels derived from thermal and chemical conversion of the Greek transport sector. Sci. Eng. Prog. 2020, 17, 100387. [CrossRef]

11. Dung, T.N.B.; Sen, B.; Chen, C.C.; Kumar, G.; Lin, C.Y. Food waste to bioenergy via anaerobic processes. Energy Procedia 2014, 61, 307-312. [CrossRef]

12. Alaswad, A.; Dassisti, M.; Prescott, T.; Olabi, A.G. Technologies and developments of third generation biofuel production. Renew. Sustain. Energy Rev. 2015, 51, 1446-1460. [CrossRef]

13. Saladini, F.; Patrizi, N.; Pulselli, F.M.; Marchettini, N.; Bastianoni, S. Guidelines for emergy evaluation of first, second and third generation biofuels. Renew. Sustain. Energy Rev. 2016, 66, 221-227. [CrossRef] 
14. Schulte, L.A.; Ontl, T.A.; Larsen, G.L. Biofuels and biodiversity, wildlife habitat restoration. In Encyclopedia of Biodiversity, 2nd ed.; Levin, S.A., Ed.; Academic Press: Waltham, MA, USA, 2013; pp. 540-551.

15. Cruz, C.H.B.; Souza, G.M.; Cortez, L.A.B. Biofuels for Transport. In Future Energy; Letcher, T.M., Ed.; Elsevier: London, UK, 2014; pp. 215-244.

16. Ruan, R.; Zhang, Y.; Chen, P.; Liu, S.; Fan, L.; Zhou, N.; Ding, K.; Peng, P.; Addy, M.; Cheng, Y.; et al. Biofuels: Introduction. In Biofuels: Alternative Feedstocks and Conversion Processes for the Production of Liquid and Gaseous Biofuels, 2nd ed.; Pandey, A., Larroche, C., Dussap, C.G., Gnansounou, E., Khanal, S.K., Ricke, S., Eds.; Academic Press: Waltham, MA, USA, 2019 ; pp. 3-43.

17. Janampelli, S.; Darbha, S. Hydrodeoxygenation of vegetable oils and fatty acids over different group VIII metal catalysts for producing biofuels. Catal. Surv. Asia 2019, 23, 90-101. [CrossRef]

18. Wu, B.; Bai, X.; Liu, W.; Lin, S.; Liu, S.; Luo, L.; Guo, Z.; Zhao, S.; Lv, Y.; Zhu, C.; et al. Non-negligible stack emissions of non-criteria air pollutants from coal-fired power plants in China: Condensable particulate matter and sulfur trioxide. Environ. Sci. Technol. 2020, 54, 6540-6550. [CrossRef] [PubMed]

19. Appavu, P.; Ramanan, M.V.; Jayaraman, J.; Venu, H. NOx emission reduction techniques in biodiesel-fuelled CI engine: A review. Aust. J. Mech. Eng. 2021, 18, 210-220. [CrossRef]

20. Navas, M.B.; Ruggera, J.F.; Lick, I.D.; Casella, M.L. A sustainable process for biodiesel production using Zn/Mg oxidic species as active, selective and reusable heterogeneous catalysts. Bioresour. Bioprocess. 2020, 7, 4. [CrossRef]

21. Pugazhendhi, A.; Alagumalai, A.; Mathimani, T.; Atabani, A. Optimization, kinetic and thermodynamic studies on sustainable biodiesel production from waste cooking oil: An Indian perspective. Fuel 2020, 273, 117725. [CrossRef]

22. Darby, H.M.; Callahan, C.W. On-farm oil-based biodiesel production. In Bioenergy; Elsevier: London, UK, 2020; pp. 157-184. [CrossRef]

23. Smith, N. The Creation of an Inclusive and Safe Biofuel Production Method; Research Paper; Savannah State University: Sannah, GA, USA, 2019.

24. Yaghoubi, J.; Yazdanpanah, M.; Komendantova, N. Iranian agriculture advisors' perception and intention toward biofuel: Green way toward energy security, rural development and climate change mitigation. Renew. Energy 2019, 130, 452-459. [CrossRef]

25. Szabó, Z. Can biofuel policies reduce uncertainty and increase agricultural yields through stimulating investments? Biofuels Bioprod. Biorefining 2019, 13, 1224-1233. [CrossRef]

26. Chintala, V. Coal versus biofuels: A social and economic assessment. In Second and Third Generation of Feedstocks; Elsevier: London, UK, 2019; pp. 513-529.

27. Oyewole, S.O.; Ishola, B.; Oyewole, A.L. Socioeconomic issues associated with campaign for large scale jatropha production to meet the anticipated biofuel demand. Int. J. For. Plant 2019, 2, 19-25.

28. Topcu, M.; Tugcu, C.T. The impact of renewable energy consumption on income inequality: Evidence from developed countries. Renew. Energy 2020, 151, 1134-1140. [CrossRef]

29. Schuenemann, F.; Kerr, W.A. European union non-tariff barriers to imports of African biofuels. Agrekon 2019, 58, 407-425. [CrossRef]

30. Mattioda, R.A.; Tavares, D.R.; Casela, J.L.; Junior, O.C. Social life cycle assessment of biofuel production. In Biofuels for a More Sustainable Future; Ren, J., Scipioni, A., Manzardo, A., Liang, H., Eds.; Elsevier: London, UK, 2020; pp. 255-271. [CrossRef]

31. Siddiqui, M.R.; Miranda, A.; Mouradov, A. Microalgae as bio-converters of wastewater into biofuel and food. In Water Scarcity and Ways to Reduce the Impact; Pannirselvam, M., Shu, L., Griffin, G., Philip, L., Natarajan, A., Hussain, S., Eds.; Springer: New York, NY, USA, 2019; pp. 75-94. [CrossRef]

32. Ingle, A.P.; Ingle, P.; Gupta, I.; Rai, M. Socioeconomic impacts of biofuel production from lignocellulosic biomass. In Sustainable Bioenergy; Rais, M., Ingle, A., Eds.; Elsevier: London, UK, 2019; pp. 347-366.

33. Vassilev, S.V.; Vassileva, C.G. Composition, properties and challenges of algae biomass for biofuel application: An overview. Fuel 2016, 181, 1-33. [CrossRef]

34. Meyer, K.; Newman, P. A quota for agricultural GHG emissions (methane and nitrous oxide). In Planetary Accounting; Meyer, K., Newman, P., Eds.; Springer: Singapore, 2020; pp. 137-145. [CrossRef]

35. Patidar, S.K.; Raheman, H. Performance and durability analysis of a single-cylinder direct injection diesel engine operated with water emulsified biodiesel-diesel fuel blend. Fuel 2020, 273, 117779. [CrossRef]

36. Adewuyi, A. Challenges and prospects of renewable energy in Nigeria: A case of bioethanol and biodiesel production. Energy Rep. 2020, 6, 77-88. [CrossRef]

37. Mandley, S.; Daioglou, V.; Junginger, H.; van Vuuren, D.; Wicke, B. EU bioenergy development to 2050. Renew. Sustain. Energy Rev. 2020, 127, 109858. [CrossRef]

38. Knapczyk, A.; Francik, S.; Fraczek, J.; Slipek, Z. Analysis of research trends in production of solid biofuels. In Proceedings of the 18th International Scientific Conference "Engineering for Rural Development", Jelgava, Latvia, 22-24 May 2019; Latvia University of Life Sciences and Technologies: Jelgava, Latvia, 2019; pp. 1503-1509.

39. Chua, S.Y.; Goh, C.M.H.; Tan, Y.H.; Mubarak, N.M.; Kansedo, J.; Khalid, M.; Walvekar, R.; Abdullah, E. Biodiesel synthesis using natural solid catalyst derived from biomass waste-A review. J. Ind. Eng. Chem. 2020, 81, 41-60. [CrossRef]

40. Morato, T.; Vaezi, M.; Kumar, A. Assessment of energy production potential from agricultural residues in Bolivia. Renew. Sustain. Energy Rev. 2019, 102, 14-23. [CrossRef] 
41. Islas, J.; Manzini, F.; Masera, O.; Vargas, V. Solid biomass to heat and power. In The Role of Bioenergy in the Bioeconomy; Lago, C., Caldés, N., Lechón, Y., Eds.; Elsevier: London, UK, 2019; pp. 145-177.

42. Carrasco-Diaz, G.; Perez-Verdin, G.; Escobar-Flores, J.; Marquez-Linares, M.A. A technical and socioeconomic approach to estimate forest residues as a feedstock for bioenergy in northern Mexico. Ecosyst 2019, 6, 45. [CrossRef]

43. Rupp, S.P.; Ribic, C.A. Second-generation feedstocks from dedicated energy crops. In Renewable Energy and Wildlife Conservation; Moorman, C.E., Grodsky, S.M., Rupp, S.P., Eds.; Baltimore University Press: Baltimore, MD, USA, 2019; pp. 64-66.

44. Ho, D.P.; Ngo, H.H.; Guo, W. A mini review on renewable sources for biofuel. Bioresour. Technol. 2014, 169, 742-749. [CrossRef] [PubMed]

45. IEA. Tracking Transport 2019, Paris. Available online: https://www.iea.org/reports/tracking-transport-2019 (accessed on 21 June 2020).

46. Moriarty, P.; Yan, X.; Wang, S.J. Liquid biofuels: Not a long-term transport solution. Energy Procedia 2019, 158, 3265-3270. [CrossRef]

47. Jacobson, M.Z. Why Not Liquid Biofuels for Transportation as Part of a 100\% Wind-Water-Solar (WWS) and Storage Solution to Global Warming, Air Pollution, and Energy Security. 2020. Available online: https://web.stanford.edu/group/efmh/jacobson/ Articles/I/BiofuelVsWWS.pdf (accessed on 21 June 2020).

48. Huang, H.; Jin, Q. Industrial waste valorization: Applications to the case of liquid biofuels. green energy to sustainability: Strategies for global industries. In Green Energy to Sustainability: Strategies for Global Industries; Vertès, A.A., Qureshi, N., Blaschek, H.P., Yukawa, H., Eds.; John Wiley \& Sons: New York, NY, USA, 2020; pp. 515-537. [CrossRef]

49. Guo, M. The global scenario of biofuel production and development. In Practices and Perspectives in Sustainable Bioenergy; Mitra, M., Nagchaudhuri, A., Eds.; Springer: New Delhi, India, 2020; pp. 29-56.

50. Demain, A.L.; Báez-Vásquez, M.A. Biofuels of the present and the future. In New and Future Developments in Catalysis; Suib, S.L., Ed.; Elsevier: Oxford, UK, 2013; pp. 325-364.

51. Bharathiraja, B.; Jayamuthunagai, J.; Chakravarthy, M.; Kumar, R.P. Bioprocessing of biofuels for green and clean environment. In Bioprocess Engineering for a Green Environment; Sivasubramanian, V., Ed.; CRC Press: Boca Raton, FL, USA, 2018 ; pp. $237-249$.

52. IEA. Technology Roadmap. Biofuels for Transport. Available online: https://www.ieabioenergy.com/wp-content/uploads/2013 /10/IEA-Biofuel-Roadmap.pdf (accessed on 9 June 2020).

53. Doshi, A.; Pascoe, S.; Coglan, L.; Rainey, T.J. Economic and policy issues in the production of algae-based biofuels: A review. Renew. Sustain. Energy Rev. 2016, 64, 329-337. [CrossRef]

54. Oh, Y.K.; Hwang, K.R.; Kim, C.; Kim, J.R.; Lee, J.S. Recent developments and key barriers to advanced biofuels: A short review. Bioresour. Technol. 2018, 257, 320-333. [CrossRef]

55. Zabed, H.; Sahu, J.N.; Suely, A.; Boyce, A.N.; Faruq, G. Bioethanol production from renewable sources: Current perspectives and technological progress. Renew. Sustain. Energy Rev. 2017, 71, 475-501. [CrossRef]

56. Dalena, F.; Senatore, A.; Iulianelli, A.; Di Paola, L.; Basile, M.; Basile, A. Ethanol from biomass: Future and perspectives. In Ethanol; Basile, A., Iulianelli, A., Dalena, F., Veziroğlu, T.N., Eds.; Elsevier: London, UK, 2019; pp. 25-59.

57. Rulli, M.C.; Bellomi, D.; Cazzoli, A.; De Carolis, G.; D'Odorico, P. The water-land-food nexus of first-generation biofuels. Sci. Rep. 2016, 6, 22521. [CrossRef] [PubMed]

58. Senatore, A.; Dalena, F.; Sola, A.; Marino, A.; Valletta, V.; Basile, A. First-generation feedstock for bioenergy production. In Second and Third Generation of Feedstocks; Basile, A., Dalena, F., Eds.; Elsevier: London, UK, 2019; pp. 35-57.

59. Aditiya, H.B.; Mahlia, T.M.I.; Chong, W.T.; Nur, H.; Sebayang, A.H. Second generation bioethanol production: A critical review. Renew. Sustain. Energy Rev. 2016, 66, 631-653. [CrossRef]

60. Binod, P.; Gnansounou, E.; Sindhu, R.; Pandey, A. Enzymes for second generation biofuels: Recent developments and future perspectives. Bioresour. Technol. Rep. 2019, 5, 317-325. [CrossRef]

61. Akhtar, A.; Jiricek, I.; Krepl, V.; Mehrabadi, A. Improving the Stability of Wastewater Derived Microalgae Carbon Materials: Products Characterization, and Kinetic Modelling. Available online: https://chemrxiv.org/articles/preprint/Improving_the_ Stability_of_Wastewater_Derived_Microalgae_Carbon_Materials_Products_Characterization_and_Kinetic_Modelling/113018 96/2 (accessed on 21 June 2020).

62. Bharadwaj, S.V.; Ram, S.; Pancha, I.; Mishra, S. Recent trends in strain improvement for production of biofuels from microalgae. In Microalgae Cultivation for Biofuels Production; Yousuf, A., Ed.; Elsevier: London, UK, 2020; pp. 211-225.

63. Mathimani, T.; Pugazhendhi, A. Utilization of algae for biofuel, bio-products and bio-remediation. Biocatal. Agric. Biotechnol. 2019, 17, 326-330. [CrossRef]

64. Rajak, R.C.; Jacob, S.; Kim, B.S. A holistic zero waste biorefinery approach for macroalgal biomass utilization: A review. Sci. Total Environ. 2020, 716, 137067. [CrossRef] [PubMed]

65. Aparicio, E.; Rodríguez-Jasso, R.M.; Lara, A.; Loredo-Treviño, A.; Aguilar, C.N.; Kostas, E.T.; Ruiz, H.A. Biofuels production of third generation biorefinery from macroalgal biomass in the Mexican context: An overview. In Sustainable Seaweed Technologies; Torres, M.D., Kraan, S., Dominguez, H., Eds.; Elsevier: Amsterdam, The Netherlands, 2020; pp. $393-446$.

66. Vo, H.N.P.; Ngo, H.H.; Guo, W.; Chang, S.W.; Nguyen, D.D.; Chen, Z.; Wang, X.C.; Chen, R.; Zhang, X. Microalgae for saline wastewater treatment: A critical review. Crit. Rev. Environ. Sci. Technol. 2019, 50, 1224-1265. [CrossRef] 
67. Chen, C.Y.; Kuo, E.W.; Nagarajan, D.; Ho, S.H.; Dong, C.D.; Lee, D.G.; Chang, J.-S. Cultivating Chlorella sorokiniana AK-1 with swine wastewater for simultaneous wastewater treatment and algal biomass production. Bioresour. Technol. 2020, 302, 122814. [CrossRef]

68. Zhu, C.; Zhai, X.; Xi, Y.; Wang, J.; Kong, F.; Zhao, Y.; Chi, Z. Progress on the development of floating photobioreactor for microalgae cultivation and its application potential. World J. Microb. Biotechnol. 2019, 35, 190. [CrossRef]

69. IEA. State of Technology Review-Algae Bioenergy an IEA Bioenergy Inter-Task Strategic Project. Available online: https: //www.ieabioenergy.com/wp-content/uploads/2017/02/IEA-Bioenergy-Algae-report-update-Final-template-20170131.pdf (accessed on 26 June 2020).

70. Raheem, A.; Wan Azlina, W.A.K.G.; Taufiq Yap, Y.H.; Danquah, M.K.; Harun, R. Thermochemical conversion of microalgal biomass for biofuel production. Renew. Sustain. Energy Rev. 2015, 49, 990-999. [CrossRef]

71. Kumar, K.; Ghosh, S.; Angelidaki, I.; Holdt, S.L.; Karakashev, D.B.; Morales, M.A.; Das, D. Recent developments on biofuels production from microalgae and macroalgae. Renew. Sustain. Energy Rev. 2016, 65, 235-249. [CrossRef]

72. Sillanpää, M.; Ncibi, M.C. A Sustainable Bioeconomy: The Green Industrial Revolution; Springer: Cham, Switzerland, 2017; pp. 120-136.

73. Rosenberg, J.N.; Mathias, A.; Korth, K.; Betenbaugh, M.J.; Oyler, G.A. Microalgal biomass production and carbon dioxide sequestration from an integrated ethanol biorefinery in Iowa: A technical appraisal and economic feasibility evaluation. Biomass Bioenerg. 2011, 35, 3865-3876. [CrossRef]

74. Nandan, S. Biofuel Production Technology from bioenergy crop-algae biofuel. SSRN Electron. J. 2020, 1-12. [CrossRef]

75. Marella, T.K.; Datta, A.; Patil, M.D.; Dixit, S.; Tiwari, A. Biodiesel production through algal cultivation in urban wastewater using algal floway. Bioresour. Technol. 2019, 280, 222-228. [CrossRef]

76. Bleakley, S.; Hayes, M. Algal proteins: Extraction, application, and challenges concerning production. Foods 2017, 6, 33. [CrossRef] [PubMed]

77. Agrawal, K.; Bhatt, A.; Bhardwaj, N.; Kumar, B.; Verma, P. Algal biomass: Potential renewable feedstock for biofuels production-Part I. In Biofuel Production Technologies. Critical Analysis for Sustainability; Srivastava, N., Srivastava, M., Mishra, P.K., Gupta, V.K., Eds.; Springer: Cham, Switzerland, 2020; pp. 203-237.

78. Sander, K.; Murthy, G.S. Life cycle analysis of algae biodiesel. Int. J. Life Cycle Assess. 2010, 15, 704-714. [CrossRef]

79. Bibi, R.; Ahmad, Z.; Imran, M.; Hussain, S.; Ditta, A.; Mahmood, S.; Khalid, A. Algal bioethanol production technology: A trend towards sustainable development. Renew. Sustain. Energy Rev. 2017, 71, 976-985. [CrossRef]

80. Karthikeyan, S.; Periyasamy, M.; Prathima, A.; Sabariswaran, K. Performance analysis of diesel engine fueled with S. marginatum Macro algae biofuel-diesel blends. Mater. Today 2020, 33, 3464-3469. [CrossRef]

81. Dharmaprabhakaran, T.; Karthikeyan, S.; Periyasamy, M.; Mahendran, G. Algal biodiesel-promising source to power CI engines. Mater. Today 2020, 33, 2870-2873. [CrossRef]

82. Laurens, L.M. Whole algal biomass in situ transesterification to fatty acid methyl esters as biofuel feedstocks. In Bioenergy; Dahiya, A., Ed.; Elsevier: London, UK, 2020; pp. 525-537. [CrossRef]

83. Sulieman, A.M.E.; Rahman, E.H.A.; Ahmed, W.A. Capabilities of algae to be utilized as a renewable energy source. Acad. J. Life Sci. 2020, 6, 18-26. [CrossRef]

84. Alam, F.; Date, A.; Rasjidin, R.; Mobin, S.; Moria, H.; Baqui, A. Biofuel from algae-is it a viable alternative? Procedia Eng. 2012, 49, 221-227. [CrossRef]

85. Chalivendra, S. Bioremediation of Wastewater Using Microalgae. Doctoral Thesis, University of Dayton, Dayton, OH, USA, 2014. Available online: https:/ / ecommons.udayton.edu/graduate_theses/779/ (accessed on 21 June 2020).

86. Behera, S.; Singh, R.; Arora, R.; Sharma, N.K.; Shukla, M.; Kumar, S. Scope of algae as third generation biofuels. Front. Bioeng. Biotechnol. 2015, 2, 90. [CrossRef]

87. Moravvej, Z.; Makarem, M.A.; Rahimpour, M.R. The fourth generation of biofuel. In Second and Third Generation of Feedstocks; Basile, A., Dalena, F., Eds.; Elsevier: London, UK, 2019; pp. 557-597.

88. Naghshbandi, M.P.; Tabatabaei, N.; Aghbashlo, M.; Aftab, M.N.; Iqbal, I. Metabolic engineering of microalgae for biofuel production. In Biofuels from Algae; Spilling, K., Ed.; Springer: Cham, Switzerland, 2019; pp. 153-172.

89. Ghag, S.B.; Vavilala, S.L.; D'Souza, J.S. Metabolic engineering and genetic manipulation of novel biomass species for biofuel production. In Advanced Bioprocessing for Alternative Fuels, Biobased Chemicals, and Bioproducts; Hosseini, M., Ed.; Elsevier: London, UK, 2019; pp. 13-34.

90. Pereira, A.G.; Jimenez-Lopez, C.; Fraga, M.; Lourenço-Lopes, C.; García-Oliveira, P.; Lorenzo, J.M.; Perez-Lamela, C.; Prieto, M.A.; Simal-Gandara, J. Extraction, properties, and applications of bioactive compounds obtained from microalgae. Curr. Pharm. Des. 2020, 26, 1929-1950. [CrossRef]

91. Al Hattab, M.; Ghaly, A. Production of biodiesel from marine and freshwater microalgae: A review. Adv. Res. 2015, 3, 107-155. [CrossRef]

92. Ziolkowska, J.R. Introduction to biofuels and potentials of nanotechnology. In Green Nanotechnology for Biofuel Production; Biofuel and Biorefinery Technologies; Srivastava, N., Srivastava, M., Pandey, H., Mishra, P.K., Ramteke, P.W., Eds.; Springer: Cham, Switzerland, 2018; pp. 1-15. [CrossRef]

93. Merugu, R. Green Synthesis approach to fabricate nanomaterials. In Nanomaterials in Biofuels Research; Clean Energy Production Technologies; Srivastava, M., Srivastava, N., Mishra, P., Gupta, V., Eds.; Springer: Singapore, 2020; pp. 75-113. [CrossRef] 
94. Barker, J.; Richard, P.; Snape, C.; Meredith, W. Diesel injector deposits-An issue that has evolved with engine technology. SAE Tech. Pap. 2011, 148, 7191.

95. Karikalan, L.; Chandrasekaran, M.; Sudhagar, K. Comparative studies on vegetable oil usage in CI engines as an alternative to diesel fuel. IREME J. 2013, 7, 705-715.

96. Naik, S.N.; Goud, V.V.; Rout, P.K.; Dalai, A.K. Production of first and second generation biofuels: A comprehensive review. Renew. Sustain. Energy Rev. 2010, 14, 578-597. [CrossRef]

97. Akhlaghi, S.; Gedde, U.W.; Hedenqvist, M.S.; Braña, M.T.C.; Bellander, M. Deterioration of automotive rubbers in liquid biofuels: A review. Renew. Sustain. Energy Rev. 2015, 43, 1238-1248. [CrossRef]

98. Jamwal, V.L.; Kapoor, N.; Gandhi, S.G. Biotechnology of biofuels: Historical overview, business outlook and future perspectives In Biotechnology Business - Concept to Delivery; Saxena, A., Ed.; Springer: Cham, Switzerland, 2020; pp. 109-127. [CrossRef]

99. Lesun, A.; Kazak, A.; Bankovskaya, I. Biofuels. 2019. Available online: https://rep.bntu.by/bitstream/handle/data/60791/64-6 7.pdf? sequence=1 (accessed on 9 June 2020).

100. Neto, J.M.; Komesu, A.; da Silva Martins, L.H.; Gonçalves, V.O.; de Oliveira, J.A.R.; Rai, M. Third generation biofuels: An overview. In Sustainable Bioenergy; Rai, M., Avinash, P.I., Eds.; Elsevier: London, UK, 2019; pp. 283-298. [CrossRef]

101. Algayyim, S.J.M.; Wandel, A.P.; Yusaf, T.; Hamawand, I. Production and application of ABE as a biofuel. Renew. Sustain. Energy Rev. 2018, 82, 1195-1214. [CrossRef]

102. Rodionova, M.V.; Poudyal, R.S.; Tiwari, I.; Voloshin, R.A.; Zharmukhamedov, S.K.; Nam, H.G.; Zayadan, B.; Bruce, B.; Hou, H.; Allakhverdiev, S. Biofuel production: Challenges and opportunities. Int. J. Hydrog. Energy 2017, 42, 8450-8461. [CrossRef]

103. Noraini, M.; Ong, H.C.; Badrul, M.J.; Chong, W. A review on potential enzymatic reaction for biofuel production from algae. Renew. Sustain. Energy Rev. 2014, 39, 24-34. [CrossRef]

104. Mahjoub, N.; Sahebi, H.; Mazdeh, M.; Teymouri, A. Optimal design of the second and third generation biofuel supply network by a multi-objective model. J. Clean Prod. 2020, 256, 120355. [CrossRef]

105. Chowdhury, H.; Loganathan, B. Third-generation biofuels from microalgae: A review. Curr. Opin. Green Sustain. Chem. 2019, 20, 39-44. [CrossRef]

106. Ziolkowska, J.R. Biofuels technologies: An overview of feedstocks, processes, and technologies. In Biofuels for a More Sustainable Future; Jingzheng, R., Antonio, S., Alessandro, M., Hanwei, L., Eds.; Elsevier: London, UK, 2020; pp. 1-19.

107. Fasahati, P.; Liu, J.J.; Ohlrogge, J.B.; Saffron, C.M. Process design and economics for production of advanced biofuels from genetically modified lipid-producing sorghum. Appl. Energy 2019, 239, 1459-1470. [CrossRef]

108. Hao, H.; Liu, Z.; Zhao, F.; Ren, J.; Chang, S.; Rong, K.; Du, J. Biofuel for vehicle use in China: Current status, future potential and policy implications. Renew. Sustain. Energy Rev. 2018, 82, 645-653. [CrossRef]

109. Nguyen, D.C.; Pham, V.V. Pathway of sustainable fuel development with novel generation biofuels. AIP Conf. Proc. 2020, 2235, 020012. [CrossRef]

110. Barry, T.; Crisby, C.; LaBossiere, M.; Luft, R.; Peterson, D.; Thompson, D.; Yeske, R. Biofuels: The Potential Opportunities and the Realistic Limitations; University of Victoria: Victoria, BC, Canada, 2020; pp. 2-16. Available online: https://web.uvic.ca/ \{\}djberg/ Chem300A/GroupGH_Biofuels_Proj1.pdf (accessed on 9 June 2020).

111. Tavizón-Pozos, J.A.; Ibarra, I.S.; Guevara-Lara, A.; Galán-Vidal, C.A. Application of design of experiments in biofuel production: A review. In Design of Experiments for Chemical, Pharmaceutical, Food, and Industrial Applications; Rodríguez-Ávila, J.A., ArredondoSoto, K.C., Cornejo-Bravo, J.M., Eds.; IGI Global: Hershey PA, USA, 2020; pp. 77-103.

112. Alalwan, H.A.; Alminshid, H.A.; Aljaafari, H.A. Promising evolution of biofuel generations. Renew. Energy Focus 2019, 28, 127-139. [CrossRef]

113. Li, X.; Luo, X.; Jin, Y.; Li, J.; Zhang, H.; Zhang, A.; Xie, J. Heterogeneous sulfur-free hydrodeoxygenation catalysts for selectively upgrading the renewable bio-oils to second generation biofuels. Renew. Sustain. Energy Rev. 2018, 82, 3762-3797. [CrossRef]

114. Joshi, G.; Pandey, J.K.; Rana, S.; Rawat, D.S. Challenges and opportunities for the application of biofuel. Renew. Sustain. Energy Rev. 2017, 79, 850-866. [CrossRef]

115. Du, C.; Zhao, X.; Liu, D.; Lin, C.S.K.; Wilson, K.; Luque, R.; Clark, J. Introduction: An overview of biofuels and production technologies. In Handbook of Biofuels Production; Luque, R., Ki Lin, C.S., Wilson, K., Clark, J., Eds.; Elsevier: London, UK, 2016; pp. 3-12.

116. Gupta, V.K.; Potumarthi, R.; O’Donovan, A.; Kubicek, C.P.; Sharma, G.D.; Tuohy, M.G. Bioenergy research: An overview on technological developments and bioresources. In Bioenergy Research: Advances and Applications; Gupta, V.K., Tuohy, M.G., Kubicek, C.P., Saddler, J., Xu, F., Eds.; Elsevier: London, UK, 2014; pp. 23-47.

117. Fokaides, P.; Christoforou, E. Life cycle sustainability assessment of biofuels. In Handbook of Biofuels Production; Luque, R., Ki Lin, C.S., Wilson, K., Clark, J., Eds.; Elsevier: London, UK, 2016; pp. 41-60.

118. Knapczyk, A.; Francik, S.; Wójcik, A.; Ślipek, Z. Application of methods for scheduling tasks in the production of biofuels. In Renewable Energy Sources: Engineering, Technology, Innovation; Wróbel, M., Jewiarz, M., Szlęk, A., Eds.; Springer: Cham, Switzerland, 2020; pp. 863-873.

119. Isah, S.; Ozbay, G. Valorization of food loss and wastes: Feedstocks for biofuels and valuable chemicals. Front. Sustain. Food Syst. 2020, 4, 82. [CrossRef]

120. Rajak, U.; Verma, T.N. Effect of emission from ethylic biodiesel of edible and non-edible vegetable oil, animal fats, waste oil and alcohol in CI engine. Energy Convers. Manag. 2018, 166, 704-718. [CrossRef] 
121. Ahamed, M.; Dash, S.; Kumar, A.; Lingfa, P. A critical review on the production of biodiesel from Jatropha, Karanja and Castor feedstocks. In Bioresource Utilization and Bioprocess; Ghosh, S., Sen, R., Chanakya, H., Pariatamby, A., Eds.; Springer: Singapore, 2020; pp. 107-115.

122. Hadin, A.; Eriksson, O. Horse manure as feedstock for anaerobic digestion. Waste Manag. 2016, 56, 506-518. [CrossRef]

123. Ajanovic, A. Biofuels versus food production: Does biofuels production increase food prices? Energy 2011, 36, 2070-2076. [CrossRef]

124. Callegari, A.; Bolognesi, S.; Cecconet, D.; Capodaglio, A.G. Production technologies, current role, and future prospects of biofuels feedstocks: A state-of-the-art review. Crit. Rev. Environ. Sci. Technol. 2020, 50, 384-436. [CrossRef]

125. Al Hatrooshi, A.S.; Eze, V.C.; Harvey, A.P. Production of biodiesel from waste shark liver oil for biofuel applications. Renew. Energy 2020, 145, 99-105. [CrossRef]

126. Patel, A.; Sartaj, K.; Pruthi, P.A.; Pruthi, V.; Matsakas, L. Utilization of clarified butter sediment waste as a feedstock for cost-effective production of biodiesel. Foods 2019, 8, 234. [CrossRef]

127. Ekeoma, M.; Okoye, P.; Ajiwe, V.; Hameed, B. Modified coconut shell as active heterogeneous catalyst for the transesterification of waste cooking oil. J. Chem. Soc. Niger. 2020, 45, 107.

128. Ndiaye, M.; Arhaliass, A.; Legrand, J.; Roelens, G.; Kerihuel, A. Reuse of waste animal fat in biodiesel: Biorefining heavilydegraded contaminant-rich waste animal fat and formulation as diesel fuel additive. Renew. Energy 2020, 145, 1073-1079. [CrossRef]

129. Nikhom, R.; Mueanmas, C.; Suppalakpanya, K.; Tongurai, C. Utilization of oil recovered from biodiesel wastewater as an alternative feedstock for biodiesel production. Environ. Prog. Sustain. Energy 2020, 39, 13365. [CrossRef]

130. Hess, J.R.; Ray, A.E.; Rials, T.G. Advancements in biomass feedstock preprocessing: Conversion ready feedstocks. Front. Energy Res. 2019, 7, 140. [CrossRef]

131. Puettmann, M.; Sahoo, K.; Wilson, K.; Oneil, E. Life cycle assessment of biochar produced from forest residues using portable systems. J. Clean. Prod. 2020, 250, 119564. [CrossRef]

132. Abdulkareem-Alsultan, G.; Asikin-Mijan, N.; Lee, H.; Taufiq-Yap, Y. Biofuels: Past, Present, Future. In Innovations in Sustainable Energy and Cleaner Environment; Springer: Berlin/Heidelberg, Germany, 2020; pp. 489-504.

133. Sindhu, R.; Binod, P.; Pandey, A.; Ankaram, S.; Duan, Y.; Awasthi, M.K. Biofuel production from biomass: Toward sustainable development. In Current Developments in Biotechnology and Bioengineering; Larroche, C., Sanroman, M., Du, G., Pandey, A., Eds.; Elsevier: London, UK, 2019; pp. 79-92.

134. Nwoba, E.G.; Vadiveloo, A.; Ogbonna, C.N.; Ubi, B.E.; Ogbonna, J.C.; Moheimani, N.R. Algal cultivation for treating wastewater in African developing countries: A review. Clean Soil Air Water 2020, 48, 2000052. [CrossRef]

135. Veeramuthu, A.; Ngamcharussrivichai, C. Potential of microalgal biodiesel: Challenges and applications. IntechOpen 2020, 9 , 51-60. [CrossRef]

136. Chew, B.; Shen, X.; Ansell, J.; Hamid, S.; Oh, Y. Review a decade of BP's Technology roadmap on the next generation biofuels development. IOP Conf. Ser. Earth Environ. Sci. 2019, 268, 012009. [CrossRef]

137. Singh, D.; Sharma, D.; Soni, S.L.; Sharma, S.; Sharma, K.P.; Jhalani, A. A review on feedstocks, production processes, and yield for different generations of biodiesel. Fuel 2020, 262, 116553. [CrossRef]

138. Soriano, A.; Kostrinsky, S.; Gikonyo, B. Alfalfa Hay as Non-Human Feedstock for Second Generation Biofuels: Hope or Hoax? Part II; SUNY Geneseo: Geneseo, NY, USA, 2020; Available online: https: / /knightscholar.geneseo.edu/cgi/viewcontent.cgi?article=1027 \&context=great-day-symposium (accessed on 6 June 2020).

139. Saini, S.; Chandel, A.K.; Sharma, K.K. Past practices and current trends in recovery and purification of first generation ethanol: A learning curve for lignocellulosic ethanol. J. Clean. Prod. 2020, 268, 122357. [CrossRef]

140. Chen, W.H.; Chen, Y.C.; Lin, J.G. Evaluation of biobutanol production from non-pretreated rice straw hydrolysate under non-sterile environmental conditions. Bioresour. Technol. 2013, 135, 262-268. [CrossRef]

141. Santos, F.; Eichler, P.; de Queiroz, J.H.; Gomes, F. Production of second-generation ethanol from sugarcane. In Sugarcane Biorefinery, Technology and Perspectives; Santos, F., Rabelo, S., De Matos, M., Eichler, P., Eds.; Elsevier: London, UK, 2020 ; pp. 195-228.

142. Molinuevo-Salces, B.; Riaño, B.; Hernández, D.; García-González, M.C. Microalgae and wastewater treatment: Advantages and disadvantages. In Microalgae Biotechnology for Development of Biofuel and Wastewater Treatment; Alam, M.A., Wang, Z., Eds.; Springer: Cham, Switzerland, 2019; pp. 505-533.

143. Voloshin, R.A.; Rodionova, M.V.; Zharmukhamedov, S.K.; Nejat Veziroglu, T.; Allakhverdiev, S.I. Review: Biofuel production from plant and algal biomass. Int. J. Hydrog. Energy 2016, 41, 17257-17273. [CrossRef]

144. Bhan, C.; Verma, L.; Singh, J. Alternative fuels for sustainable development. In Environmental Concerns and Sustainable Development; Shukla, V., Kumar, N., Eds.; Springer: Singapore, 2020; pp. 317-331.

145. Gupta, V. Catalyst in biorefineries: Solution to promote environment sustainability in India. In Advanced Catalysis Processes in Petrochemicals and Petroleum Refining: Emerging Research and Opportunities; Al-Kinany, M., Aldrees, S.A., Eds.; IGI Global: Hershey, PA, USA, 2020; pp. 139-171.

146. Biodiesel Production and Consumption. Available online: https://knoema.com/atlas/topics/Energy/Renewables/Biodieselproduction (accessed on 26 June 2021).

147. Dutta, K.; Daverey, A.; Lin, J.G. Evolution retrospective for alternative fuels: First to fourth generation. Renew. Energy 2014, 69, 114-122. [CrossRef] 
148. Abdullah, B.; Syed, M.; Syed, A.F.; Shokravi, Z.; Ismail, S.; Kassim, K.A.; Mahmood, A.N.; Aziz, M.M. Fourth generation biofuel: A review on risks and mitigation strategies. Renew. Sustain. Energy Rev. 2019, 107, 37-50. [CrossRef]

149. Verma, P.; Sharma, M.P. Review of process parameters for biodiesel production from different feedstocks. Renew. Sustain. Energy Rev. 2016, 62, 1063-1071. [CrossRef]

150. Tacias-Pascacio, V.G.; Torrestiana-Sánchez, B.; Dal Magro, L.; Virgen-Ortíz, J.J.; Suárez-Ruíz, F.J.; Rodrigues, R.C.; FernandezLafuente, R. Comparison of acid, basic and enzymatic catalysis on the production of biodiesel after RSM optimization. Renew. Energy 2019, 135, 1-9. [CrossRef]

151. Baskar, G.; Aiswarya, R. Trends in catalytic production of biodiesel from various feedstocks. Renew. Sustain. Energy Rev. 2016, 57, 496-504. [CrossRef]

152. Veljković, V.B.; Banković-Ilić, I.B.; Stamenković, O.S. Purification of crude biodiesel obtained by heterogeneously-catalyzed transesterification. Renew. Sustain. Energy Rev. 2015, 49, 500-516. [CrossRef]

153. Musa, I.A. The effects of alcohol to oil molar ratios and the type of alcohol on biodiesel production using transesterification process. Egypt. J. Pet. 2016, 25, 21-31. [CrossRef]

154. Navas, M.B.; Lick, I.D.; Bolla, P.A.; Casella, M.L.; Ruggera, J.F. Transesterification of soybean and castor oil with methanol and butanol using heterogeneous basic catalysts to obtain biodiesel. Chem. Eng. Sci. 2018, 187, 444-454. [CrossRef]

155. Avagyan, A.B.; Singh, B. Biodiesel from Plant Oil and Waste Cooking Oil. In Biodiesel: Feedstocks, Technologies, Economics and Barrier; Avagyan, A.B., Singh, B., Eds.; Springer: Cham, Switzerland, 2019; pp. 15-75.

156. Borton, J.; Lopez, F.D.N.; Doan, L.; Holmes, W.E.; Benson, T.J. Conversion of high free fatty acid lipid feedstocks to biofuel using triazabicyclodecene catalyst (homogeneous and heterogeneous). Energy Fuels 2019. [CrossRef]

157. Sandoval, G.; Casas-Godoy, L.; Bonet-Ragel, K.; Rodrigues, J.; Ferreira-Dias, S.; Valero, F. Enzyme-catalyzed production of biodiesel as alternative to chemical-catalyzed processes: Advantages and constraints. Curr. Biochem. Eng. 2017, 4, 109-141. [CrossRef]

158. Yin, X.; Ma, H.; You, Q.; Wang, Z.; Chang, J. Comparison of four different enhancing methods for preparing biodiesel through transesterification of sunflower oil. Appl. Energy 2012, 91, 320-325. [CrossRef]

159. Mansir, N.; Teo, S.H.; Rashid, U.; Saiman, M.I.; Tan, Y.P.; Alsultan, G.A.; Taufiq-Yap, Y.H. Modified waste egg shell derived bifunctional catalyst for biodiesel production from high FFA waste cooking oil. a review. Renew. Sustain. Energy Rev. 2018, 82, 3645-3655. [CrossRef]

160. Littlewood, J.; Murphy, R.J.; Wang, L. Importance of policy support and feedstock prices on economic feasibility of bioethanol production from wheat straw in the UK. Renew. Sustain. Energy Rev. 2013, 17, 291-300. [CrossRef]

161. Gissén, C.T.; Prade, E.; Kreuger, I.A.; Nges, H.; Rosenqvist, S.; Svensson, S.-E.; Lantz, M.; Mattsson, J.E.; Börjesson, P.; Björnsson, L. Comparing energy crops for biogas production-Yields, energy input and costs in cultivation using digestate and mineral fertilisation. Biomass Bioenergy 2014, 64, 199-210. [CrossRef]

162. Mohadesi, M.; Aghel, B.; Maleki, M.; Ansari, A. The use of $\mathrm{KOH} /$ Clinoptilolite catalyst in pilot of microreactor for biodiesel production from waste cooking oil. Fuel 2020, 263, 116659. [CrossRef]

163. Naeem, A.; Wali Khan, I.; Farooq, M.; Mahmood, T.; Ud Din, I.; Ali Ghazi, Z.; Saeed, T. Kinetic and optimization study of sustainable biodiesel production from waste cooking oil using novel heterogeneous solid base catalyst. Bioresour. Technol. 2021, 328, 124831. [CrossRef]

164. Srinivasan, G.R.; Palani, S.; Munir, M.; Saeed, M.; Thangavelu, L.; Mohanam, A.; Jambulingam, R. Engine characteristics study on beef tallow biodiesel produced by ethanol based co-solvent transesterification. Energy Source Part A 2020, 1-21. [CrossRef]

165. Odetoye, T.E.; Agu, J.O.; Ajala, E.O. Biodiesel production from poultry wastes: Waste chicken fat and eggshell. J. Environ. Chem. Eng. 2021, 9, 105654. [CrossRef]

166. He, C.; Mei, Y.; Zhang, Y.; Liu, L.; Li, P.; Zhang, Z.; Jing, Y.; Li, G.; Jiao, Y. Enhanced biodiesel production from diseased swine fat by ultrasound-assisted two-step catalyzed process. Bioresour. Technol. 2020, 304, 123017. [CrossRef]

167. Karimi, S.; Karimi, K. Efficient ethanol production from kitchen and garden wastes and biogas from the residues. J. Clean. Prod. 2018, 187, 37-45. [CrossRef]

168. Casabar, J.T.; Unpaprom, Y.; Ramaraj, R. Fermentation of pineapple fruit peel wastes for bioethanol production. Biomass Convers. Biorefinery 2019, 9, 761-765. [CrossRef]

169. Wang, Y.; Li, G.; Chi, M.; Sun, Y.; Zhang, J.; Jiang, S.; Cui, Z. Effects of co-digestion of cucumber residues to corn stover and pig manure ratio on methane production in solid state anaerobic digestion. Bioresour. Technol. 2018, 250, 328-336. [CrossRef] [PubMed]

170. Shamurad, B.; Sallis, P.; Petropoulos, E.; Tabraiz, S.; Ospina, C.; Leary, P.; Dolfing, J.; Gray, N. Stable biogas production from single-stage anaerobic digestion of food waste. Appl. Energy 2020, 263, 114609. [CrossRef]

171. Wang, D.; Wang, Y.; Liu, X.; Xu, Q.; Yang, Q.; Li, X.; Zhang, Y.; Liu, Y.; Wang, Q.; Ni, B.-J.; et al. Heat pretreatment assists free ammonia to enhance hydrogen production from waste activated sludge. Bioresour. Technol. 2019, 283, 316-325. [CrossRef]

172. Argun, H.; Dao, S. Bio-hydrogen production from waste peach pulp by dark fermentation: Effect of inoculum addition. Int. J. Hydrog. Energy 2017, 42, 2569-2574. [CrossRef]

173. Hasan, A.; Dincer, I. Comparative assessment of various gasification fuels with waste tires for hydrogen production. Int. J. Hydrog. Energy 2019, 44, 18818-18826. [CrossRef]

174. Subramanian, K.A. Biofueled Reciprocating Internal Combustion Engines; CRC Press: Boca Raton, FL, USA, 2017 ; p. 15. 
175. IEA. Key World Energy Statistics. 2018. Available online: https:/ /webstore.iea.org/key-world-energy-statistics-2018 (accessed on 12 July 2020).

176. TERM. Transport Indicators Tracking Progress towards Environmental Targets in Europe; No 7/2015; European Environment Agency: Copenhagen, Denmark, 2015; Available online: https://www.eea.europa.eu/publications/term-report-2015 (accessed on 12 July 2020).

177. EIA-Energy Information Administration. International Energy Outlook. 2017. Available online: https://www.eia.gov/ outlooks/ieo/ (accessed on 4 August 2020).

178. Staffell, I.; Scamman, D.; Abad, A.V.; Balcombe, P.; Dodds, P.E.; Ekins, P.; Shah, N.; Ward, K.R. The role of hydrogen and fuel cells in the global energy system. Energy Environ. Sci. 2019, 12, 463-491. [CrossRef]

179. IRENA. Global Energy Transformation: The REmap Transition Pathway (Background Report to 2019 Edition); International Renewable Energy Agency: Abu Dhabi, United Arab Emirates, 2019; Available online: https://www.irena.org/publications/2019/Apr/ Global-energy-transformation-The-REmap-transition-pathway (accessed on 4 August 2020).

180. Gis, W. Electromobility and hydrogenization of the motor transport in Poland now and in the future. J. KONES 2018, 25, 95-101. [CrossRef]

181. Green Car. 2014. Available online: https://www.greencarreports.com/news/1093560_1-2-billion-vehicles-on-worlds-roadsnow-2-billion-by-2035-report (accessed on 4 August 2020).

182. Lamb, J.J.; Austbø, B. Current Use of Bioenergy. In Hydrogen, Biomass and Bioenergy; Jacob, J., Pollet, B.G., Eds.; Academic Press: Trondheim, Norway; Elsevier: London, UK, 2020; pp. 9-20.

183. Martins, J.; Brito, F. Alternative fuels for internal combustion engines. Energies 2020, 13, 4086. [CrossRef]

184. Lisý, M.; Lisá, H.; Jecha, D.; Baláš, M.; Križan, P. Characteristic properties of alternative biomass fuels. Energies 2020, $13,1448$. [CrossRef]

185. Aladejare, A.E.; Onifade, M.; Lawal, A.I. Application of metaheuristic based artificial neural network and multilinear regression for the prediction of higher heating values of fuels. Int. J. Coal Prep. Util. 2020, 1-22. [CrossRef]

186. Noushabadi, A.S.; Dashti, A.; Raji, M.; Zarei, A.; Mohammadi, A.H. Estimation of cetane numbers of biodiesel and diesel oils using regression and PSO-ANFIS models. Renew. Energy 2020, 4, 146. [CrossRef]

187. Huang, Y.; Li, F.; Bao, G.; Wang, W.; Wang, H. Estimation of kinematic viscosity of biodiesel fuels from fatty acid methyl ester composition and temperature. J. Chem. Eng. Data 2020, 65, 2476-2485. [CrossRef]

188. SAE International Hybrid-EV Committee. J2841: Utility Factor Definitions for Plug-In Hybrid Electric Vehicles Using Travel Survey Data; SAE International: Warrendale, PA, USA, 2010. [CrossRef]

189. Arat, H.T.; Baltacioglu, M.K.; Özcanli, M.; Aydin, K. Effect of using Hydroxy-CNG fuel mixtures in a non-modified diesel engine by substitution of diesel fuel. Int. J. Hydrog. Energy 2016, 41, 8354-8363. [CrossRef]

190. McCormick, R.L.; Fioroni, G.; Fouts, L.; Christensen, E.; Yanowitz, J.; Polikarpov, E.; Albrecht, K.; Gaspar, D.; Gladden, J.; George, A. Selection criteria and screening of potential biomass-derived streams as fuel blendstocks for advanced spark-ignition engines. SAE Int. J. Fuels Lubr. 2017, 10, 442-460. [CrossRef]

191. Mustafa, A.; Lougou, B.G.; Shuai, Y.; Wang, Z.; Tan, H. Current technology development for $\mathrm{CO}_{2}$ utilization into solar fuels and chemicals: A review. J. Energy Chem. 2020, 49, 96-123. [CrossRef]

192. Chintala, V. Production, upgradation and utilization of solar assisted pyrolysis fuels from biomass-a technical review. Renew. Sustain. Energy Rev. 2018, 90, 120-130. [CrossRef]

193. Jiao, Y.; Liu, R.; Zhang, Z.; Yang, C.; Zhou, G.; Dong, S.; Liu, W. Comparison of combustion and emission characteristics of a diesel engine fueled with diesel and methanol-Fischer-Tropsch diesel-biodiesel-diesel blends at various altitudes. Fuel 2019, 243, 52-59. [CrossRef]

194. Bongartz, D.; Doré, L.; Eichler, K.; Grube, T.; Heuser, B.; Hombach, L.E.; Robinius, M.; Pischinger, S.; Stolten, D.; Walther, G.; et al. Comparison of light-duty transportation fuels produced from renewable hydrogen and green carbon dioxide. Appl. Energy 2018, 231, 757-767. [CrossRef]

195. Bae, C.J.; Kim, J. Alternative fuels for internal combustion engines. Proc. Combust. Inst. 2017, 36, 3389-3413. [CrossRef]

196. Ileleji, K.E.; Martin, C.; Jones, D. Basics of energy production through anaerobic digestion of livestock manure. In Bioenergy; Dahiya, A., Ed.; Academic Press: Boston, MA, USA, 2015; pp. 287-295.

197. Dykstra, C.M.; Pavlostathis, S.G. Bioelectrochemical Enhancement and Intensification of Methane Production from Anaerobic Digestion. In Microbial Electrochemical Technologies; Tiquia-Arashiro, S.M., Pan, D., Eds.; CRC Press: Boca Raton, FL, USA, 2020; pp. 260-275.

198. Pramanik, S.K.; Suja, F.B.; Zain, S.M.; Pramanik, B.k. The anaerobic digestion process of biogas production from food waste: Prospects and constraints. Bioresour. Technol. Rep. 2019, 8, 100310. [CrossRef]

199. Dupnock, T.L. Development of a High Performance, Biological Trickling Filter to Upgrade Raw Biogas to Renewable Natural Gas Standards. Master's Thesis, Duke University, Durham, NC, USA, 2019.

200. Bora, D.; Barbora, L.; Borah, A.J.; Mahanta, P. A Comparative Assessment of Biogas Upgradation Techniques and Its Utilization as an Alternative Fuel in Internal Combustion Engines. In Alternative Fuels and Advanced Combustion Techniques as Sustainable Solutions for Internal Combustion Engines. Energy, Environment, and Sustainability; Singh, A.P., Kumar, D., Agarwal, A.K., Eds.; Springer: Singapore, 2021; pp. 95-115. 
201. Baena-Moreno, F.M.; Rodríguez-Galán, M.; Vega, F.; Vilches, L.F.; Navarrete, B. Recent advances in biogas purifying technologies. Int. J. Green Energy 2019, 16, 401-412. [CrossRef]

202. Baena-Moreno, F.M.; le Saché, E.; Pastor-Pérez, L.; Reina, T. Biogas as a renewable energy source: Focusing on principles and recent advances of membrane-based technologies for biogas upgrading. In Membranes for Environmental Applications; Zhang, Z., Zhang, W., Lichtfouse, E., Eds.; Springer: Cham, Switzerland, 2020; pp. 95-120.

203. Saboor, A.; Khan, S.; Ali Shah, A.; Hasan, F.; Khan, H.; Badshah, M. Enhancement of biomethane production from cattle manure with codigestion of dilute acid pretreated lignocellulosic biomass. Int. J. Hydrog. Energy 2017, 14, 632-637. [CrossRef]

204. Musthafa, M. Production of biogas from multiple feedstocks and its application as a fuel for spark ignition engines-a review. Eur. J. Sustain. Dev. Res. 2020, 4, 35-43. [CrossRef]

205. IRENA. Biogas for Road Vehicles: Technology Brief; International Renewable Energy Agency: Abu Dhabi, United Arab Emirates, 2018; Available online: https:/ / www.irena.org/_/media/Files/IRENA/Agency/Publication/2017/Mar/IRENA_Biogas_for_ Road_Vehicles_2017.pdf (accessed on 12 August 2020).

206. Angelidaki, I.; Treu, L.; Tsapekos, P.; Luo, G.; Campanaro, S.; Wenzel, H.; Kougias, P.G. Biogas upgrading and utilization: Current status and perspectives. Biotechnol. Adv. 2018, 36, 452-466. [CrossRef]

207. Stepanenko, D.; Kneba, Z. DME as alternative fuel for compression ignition engines-a review. Combust. Eng. 2019, 177, 172-179. [CrossRef]

208. Inayat, A.; Ghenai, C.; Naqvi, M.; Ammar, M.; Ayoub, M.; Hussin, M.N.B. Parametric Study for Production of Dimethyl Ether (DME) As a Fuel from Palm Wastes. Energy Procedia 2017, 105, 1242-1249. [CrossRef]

209. Evans, C.; Smith, C. Biomass to Liquids Technology. In Comprehensive Renewable Energy; Sayigh, A., Ed.; Elsevier: Oxford, UK, 2012; Volume 5, pp. 155-204.

210. Zang, G.; Sun, P.; Elgowainy, A.A.; Bafana, A.; Wang, M. Performance and cost analysis of liquid fuel production from H2 and CO2 based on the Fischer-Tropsch process. J. CO2 Util. 2021, 46, 101459. [CrossRef]

211. IRENA. Hydrogen: A Renewable Energy Perspective; International Renewable Energy Agency: Abu Dhabi, United Arab Emirates, 2019; Available online: https:/ / www.irena.org/-/media/Files/IRENA/Agency/Publication/2019/Sep/IRENA_Hydrogen_ 2019.pdf (accessed on 5 June 2021).

212. Qureshy, A.M.M.I.; Dincer, I. A new integrated renewable energy system for clean electricity and hydrogen fuel production. Int. J. Hydrog. Energy 2020, 45, 20944-20955. [CrossRef]

213. Karagöz, Y.; Balc1, Ö.; Köten, H. Investigation of hydrogen usage on combustion characteristics and emissions of a spark ignition engine. Int. J. Hydrog. Energy 2019, 44, 14243-14256. [CrossRef]

214. Ortiz-Imedio, R.; Ortiz, A.; Urroz, J.C.; Diéguez, P.M.; Gorri, D.; Gandía, L.M.; Ortiz, I. Comparative performance of coke oven gas, hydrogen and methane in a spark ignition engine. Int. J. Hydrog. Energy 2021, 46, 17572-17586. [CrossRef]

215. Akhlaghi, N.; Najafpour-Darzi, G. A comprehensive review on biological hydrogen production. Int. J. Hydrog. Energy 2020, 45, 22492-22512. [CrossRef]

216. Sharma, S.; Ghoshal, S.K. Hydrogen the future transportation fuel: From production to applications. Renew. Sustain. Energy Rev. 2015, 43, 1151-1158. [CrossRef]

217. Afanasiev, A.; Pavlov, D.; Epishkin, V.; Gapchenko, U. Application of hydrogen and hydrogen-containing gases in internal combustion engines. IOP Conf. Ser. Mater. Sci. Eng. 2020, 734, 012198. [CrossRef]

218. Asoyan, A.R.; Danilov, I.K.; Asoyan, I.A.; Polishchuk, G.M. Hydrogen application in internal combustion engines. RUDN J. Eng. Res. 2020, 21, 14-19. [CrossRef]

219. Ungureanu, N.; Vladut, V.; Biris, S.S. Capitalization of wastewater-grown algae in bioethanol production. In Proceedings of the 19th International Scientific Conference Engineering for Rural Development, Jelgava, Latvia, 20-22 May 2020; Latvia University of Life Sciences and Technologies: Jelgava, Latvia, 2020; pp. 20-22. [CrossRef]

220. Loupatty, V.; Radiena, M. Properties Activity of Yeast Against Seaweed Bioethanol Fermentation Time and Its Functional Group. J. Phys. 2020, 1463, 012018. [CrossRef]

221. Salvi, B.L.; Subramanian, K.A. Experimental investigation on effects of compression ratio and exhaust gas recirculation on backfire, performance and emission characteristics in a hydrogen fuelled spark ignition engine. Int. J. Hydrog. Energy 2016, 41, 5842-5855. [CrossRef]

222. Ceviz, M.A.; Sen, A.K.; Küleri, A.K.; Öner, I.V. Engine performance, exhaust emissions, and cyclic variations in a lean-burn SI engine fueled by gasoline-hydrogen blends. Appl. Therm Eng. 2012, 36, 314-324. [CrossRef]

223. Duan, X.; Li, Y.; Liu, J.; Guo, G.; Fu, J.; Zhang, Q.; Zhang, S.; Liu, W. Experimental study the effects of various compression ratios and spark timing on performance and emission of a lean-burn heavy-duty spark ignition engine fueled with methane gas and hydrogen blends. Energy 2019, 169, 558-571. [CrossRef]

224. Krishnaiah, R.; Kumar, S.; Devunuri, S.; Alexander, J.; Nimmakayala, M.R.; Vora, K.; Wu, Z.; Sumathy, S. Experimental investigations on lean burn spark ignition engine using methanol-gasoline blends. SAE Tech. Pap. 2019, 9. [CrossRef]

225. Gu, X.; Huang, Z.; Cai, J.; Gong, J.; Wu, X.; Lee, C.F. Emission characteristics of a spark-ignition engine fuelled with gasoline-nbutanol blends in combination with EGR. Fuel 2012, 93, 611-617. [CrossRef]

226. Turner, D.; Xu, H.; Cracknell, R.F.; Natarajan, V.; Chen, X. Combustion performance of bio-ethanol at various blend ratios in a gasoline direct injection engine. Fuel 2011, 90, 1999-2006. [CrossRef] 
227. Broustail, G.; Halter, F.; Seers, P.; Moréac, G.; Mounaim-Rousselle, C. Comparison of regulated and non-regulated pollutants with iso-octane/butanol and iso-octane/ethanol blends in a port-fuel injection spark-ignition engine. Fuel 2012, 94, $251-261$. [CrossRef]

228. Rosdi, S.; Mamat, R.; Alias, A.; Hamzah, H.; Sudhakar, K.; Hagos, F. Performance and emission of turbocharger engine using gasoline and ethanol blends. IOP Conf. Ser. Mater. Sci. Eng. 2020, 863, 012034. [CrossRef]

229. Badrawada, I.; Susastriawan, A. Influence of ethanol-gasoline blend on performance and emission of four-stroke spark ignition motorcycle. Clean. Technol. Environ. Policy 2019, 21, 1891-1896. [CrossRef]

230. Sakthivel, P.; Subramanian, K.A.; Mathai, R. Comparative studies on combustion, performance and emission characteristics of a two-wheeler with gasoline and 30\% ethanol-gasoline blend using chassis dynamometer. Appl. Eng. 2019, 146, 726-737. [CrossRef]

231. Hotta, S.K.; Sahoo, N.; Mohanty, K. Comparative assessment of a spark ignition engine fueled with gasoline and raw biogas. Renew. Energy 2019, 134, 1307-1319. [CrossRef]

232. de Faria, M.M.N.; Bueno, J.P.V.M.; Ayad, S.M.E.; Belchior, C.R.P. Thermodynamic simulation model for predicting the performance of spark ignition engines using biogas as fuel. Energy Convers. Manag. 2017, 149, 1096-1108. [CrossRef]

233. Kim, Y.; Kawahara, N.; Tsuboi, K.; Tomita, E. Combustion characteristics and NOX emissions of biogas fuels with various $\mathrm{CO}_{2}$ contents in a micro co-generation spark-ignition engine. Appl. Energy 2016, 182, 539-547. [CrossRef]

234. Muhajir, K.; Badrawada, I.; Susastriawan, A. Utilization of biogas for generator set fuel: Performance and emission characteristics. Biomass Convers. Biorefinery 2019, 9, 695-698. [CrossRef]

235. Kan, X.; Zhou, D.; Yang, W.; Zhai, X.; Wang, C.H. An investigation on utilization of biogas and syngas produced from biomass waste in premixed spark ignition engine. Appl. Energy 2018, 212, 210-222. [CrossRef]

236. Chandran, D. Compatibility of diesel engine materials with biodiesel fuel. Renew. Energy 2020, 147, 89-99. [CrossRef]

237. Méndez, C.I.; Ancheyta, J. Kinetic models for Fischer-Tropsch synthesis for the production of clean fuels. Catal. Today 2020, 335, 3-16. [CrossRef]

238. Dimethyl Ether (DME) Market. Available online: https:/ /www.globenewswire.com/news-release/2018/09/09/1568236/0/en/ Global-Dimethyl-Ether-Market-Will-Reach-USD-9-100-Million-By-2024-Zion-Market-Research.html (accessed on 31 July 2020).

239. Farsi, M.; Fekri Lari, M.; Rahimpour, M.R. Development of a green process for DME production based on the methane trireforming. J. Taiwan Inst. Chem. Eng. 2020, 106, 9-19. [CrossRef]

240. Mondal, U.; Yadav, G.D. Perspective of dimethyl ether as fuel: Part I. Catalysis. J. CO2 Util. 2019, 32, 299-320. [CrossRef]

241. Simsek, S. Effects of biodiesel obtained from Canola, sefflower oils and waste oils on the engine performance and exhaust emissions. Fuel 2020, 265, 117026. [CrossRef]

242. Hirner, F.S.; Hwang, J.; Bae, C.; Patel, C.; Gupta, T.; Agarwal, A.K. Performance and emission evaluation of a small-bore biodiesel compression-ignition engine. Energy 2019, 183, 971-982. [CrossRef]

243. Rosha, P.; Mohapatra, S.K.; Mahla, S.K.; Cho, H.; Chauhan, B.S.; Dhir, A. Effect of compression ratio on combustion, performance, and emission characteristics of compression ignition engine fueled with palm (B20) biodiesel blend. Energy 2019, 178, 676-684 [CrossRef]

244. Srikanth, H.; Venkatesh, J.; Godiganur, S.; Manne, B.; Bharath Kumar, S.; Spurthy, S. Combustion, performance, and emission characteristics of dairy-washed milk scum biodiesel in a dual cylinder compression ignition engine. Energy Source Part A 2019, 42, 1-18. [CrossRef]

245. Nirmala, N.; Dawn, S.S.; Harindra, C. Analysis of performance and emission characteristics of waste cooking oil and Chlorella variabilis MK039712.1 biodiesel blends in a single cylinder, four strokes diesel engine. Renew. Energy 2020, 147, 284-292. [CrossRef]

246. Park, S.H.; Lee, C.S. Combustion performance and emission reduction characteristics of automotive DME engine system. Prog. Energy Combust. Sci. 2013, 39, 147-168. [CrossRef]

247. Yang, S.; Lee, C. Exhaust gas characteristics according to the injection conditions in diesel and DME engines. Appl. Sci. 2019, 9, 647. [CrossRef]

248. Raza, M.; Chen, L.; Ruiz, R.; Chu, H. Influence of pentanol and dimethyl ether blending with diesel on the combustion performance and emission characteristics in a compression ignition engine under low temperature combustion mode. J. Energy Inst. 2019, 92, 1658-1669. [CrossRef]

249. Liu, H.; Wang, Z.; Zhang, J.; Wang, J.; Shuai, S. Study on combustion and emission characteristics of Polyoxymethylene Dimethyl Ethers/diesel blends in light-duty and heavy-duty diesel engines. Appl. Energy 2017, 185, 1393-1402. [CrossRef]

250. Yongcheng, H.; Longbao, Z.; Shangxue, W.; Shenghua, L. Study on the performance and emissions of a compression ignition engine fuelled with Fischer-Tropsch diesel fuel. Proc. Inst. Mech. Eng. Part D 2006, 220, 827-835. [CrossRef]

251. Alotri, B. Comprehensive Cost Assessment of Present and Future Energy Conversion Technologies. Master's Thesis, Utrecht University, Utrecht, The Netherlands, 2020. Available online: http:/ / dspace.library.uu.nl/handle/1874/397259 (accessed on 21 August 2020).

252. Ramasamy, S.; Arun, S.; Pakshirajan, K. An overview of algal photobioreactors for resource recovery from waste. In Bioreactors; Singh, L., Yousuf, A., Mahapatra, D.M., Eds.; Elsevier: London, UK, 2020; pp. 215-248.

253. Gani, P.; Sunar, N.M.; Matias-Peralta, H.M. Cultivation system and harvesting techniques in Microalgae Biomass production. Quantum J. Eng. Sci. Technol. 2020, 1, 33-44.

254. Reynoso, A.; Iriarte-Velasco, U.; Gutiérrez-Ortiz, M.; Ayastuy, J. Highly stable Pt/CoAl2O4 catalysts in aqueous-phase reforming of glycerol. Catal. Today 2020, 367, 278-289. [CrossRef] 
255. Zoppi, G.; Pipitone, G.; Gruber, H.; Weber, G.; Reichhold, A.; Pirone, R.; Bensaid, S. Aqueous phase reforming of pilot-scale Fischer-Tropsch water effluent for sustainable hydrogen production. Catal. Today 2020, 367, 239-247. [CrossRef]

256. Bullis, K. Amyris Announces Commercial Production of Biochemicals. MIT Technology Review, 29 April 2011. Available online: https:/ / www.technologyreview.com/2011/04/29/195019/amyris-announces-commercial-production-of-biochemicals / (accessed on 21 August 2020).

257. Ballesteros, M.; Manzanares, P. Liquid Biofuels. In The Role of Bioenergy in the Bioeconomy; Lago, C., Caldés, N., Lechón, Y., Eds.; Academic Press: Madrid, Spain; Elsevier: London, UK, 2019; pp. 113-144.

258. Malode, S.J.; Prabhu, K.K.; Mascarenhas, R.J.; Shetti, N.P.; Aminabhavi, T.M. Recent advances and viability in biofuel production. Energy Convers. Manag. 2021, 10, 100070. [CrossRef]

259. Adegboye, M.F.; Ojuederie, O.B.; Talia, P.M.; Babalola, O.O. Bioprospecting of microbial strains for biofuel production: Metabolic engineering, applications, and challenges. Biotechnol. Biofuels 2021, 14, 5. [CrossRef]

260. Lin, C.Y.; Lu, C. Development perspectives of promising lignocellulose feedstocks for production of advanced generation biofuels: A review. Renew. Sustain. Energy Rev. 2021, 136, 110445. [CrossRef] 